\title{
Identificaçào e caracterizaçào de alguns solos da Estação Experimental de Silvicultura Tropical do INPA
}

\author{
G. Ranzani ( ${ }^{\natural}$ )
}

\begin{abstract}
Resumo
No presente estudo, sāo identificados, caracterizados morfologica e analiticamente, nove solos sob experimentação agrícola, na Estação Experimental de Silvicultura Tropical do INPA, situada no $\mathrm{Km} 45$ da BR-174, que liga Manaus a Boa Vista. As condiçōes presentes nessa área caracterizam um regime de temperatura isohipertérmico e um regime de umidade údico. Os solos se enquadram em duas ordens: Ultissol e Oxissol. A ordem Ultissol apresenta-se com duas subordens: Humult com dois grandes grupos (Palehumult e Tropohumult) e Udult, com um grande grupo (Paleudult). A ordem Oxissol apresenta uma subordem (Orthox) com dois grandes grupos: Haplorthox e Acrorthox. Os solos, no Sistema Brasileiro de Classificação, enquadramse nas seguintes classes: Podzólico Vermelho Amarelo álico, Latossólico, A moderado, texturas média e argilosa: Podzólico Vermelho Amarelo álico, A moderado, textura argilosa e Latossolo Amarelo álico, A moderado, textura argilosa. Os resultados obtidos sobre a marcha anual da água disponível, sugerem, para alguns solos, a presença de água disponível para as plantas, durante todo $\mathrm{o}$ ano, a partir de profundidade compreendida entre 130 e $270 \mathrm{~cm}$; para outros solos, como é o caso dos perfís EEST 3 e 6, há ausência de água dispoponivel para as plantas durante 3 meses/ano.
\end{abstract}

\section{INTRODUÇÃO}

O presente trabalho faz parte de um programa de Levantamento de Solos que se realiza sob os auspícios de Convênio entre a Organização dos Estados Americanos (OEA) e o Instituto Nacional de Pesquisas da Amazônia (INPA), intitulado Ecologia da Floresta Tropical. Refere-se a áreas com experimentos recentemente instalados ou a instalar, na Estação Experimental de Silvicultura Tropical, situada no $\mathrm{Km} 45$ da BR-174 que liga Manaus a Boa Vista.

As identificações e classificações dos solos aqui apresentadas se destinam a proporcionar uma base de apoio a pesquisas que estão sendo conduzidas e a programas even. tualmente estabelecidos nessa área da Amazônia brasileira.

As observações do presente estudo incluem a morfologia e as características físicas. químicas e físico-químicas de 9 perfis de solo

\section{LoCALIzAÇão, LIMites E ÁREa da ESTAÇÃo} EXPERIMENTAL DE SILVICULTURA TROPICAL

A Estação Experimental de Silvicultura Tropical (EEST), do Instituto Nacional de Pesquisas da Amazônia - INPA, antiga Reserva Florestal da SUFRAMA, lecaliza-se a $60 \mathrm{~km}$ de Manaus, apresentando um total de 22.735 ha de terras cobertas de matas.

A rodovia BR-174 cruza a EEST deixando pequena área à direita, representada pela Reserva de Campina do INPA (Fig. 1). A maior parte da área encontra-se entre a BR-174 e o rio Cuieiras, em grande parte banhada pelos afluentes da vertente esquerda do Cuieiras e pelos tributários do alto Tarumă-Açu.

As coordenadas da área são aproximadamente as seguintes:

$2^{\circ} 35^{\prime}$ a $2^{\circ} 40^{\prime}$ latitude sul

$60^{\circ} 00^{\prime}$ a $60^{\circ} 20^{\prime}$ longitude W.G.

Confronta-se ao $\mathrm{N}$ com terras da CEPLAC; ao $\mathrm{S}$ com terras do Instituto Brasileiro de Desenvolvimento Florestal, pelo azimute de $287^{\circ} 30^{\prime}$ a $2^{\circ} 42^{\prime}$ latitude S; ao O pelo rio Cuieiras enquanto ao $E$, a divisa é marcada pela BR-174 exceto na área da Reserva de Campina que se inicia a partir do entroncamento da BR-174 com a estrada ZF1.

As terras da EEST distribuem-se entre duas bacias hidrográficas: $59 \%$ ou 13.414 ha na bacia do rio Cuieiras ao oeste e $41 \%$ ou 9.321 ha na bacia do rio Tarumã-Açu.

(•) - Instituto Nacional de Pesquisas da Amazônia, Manaus 


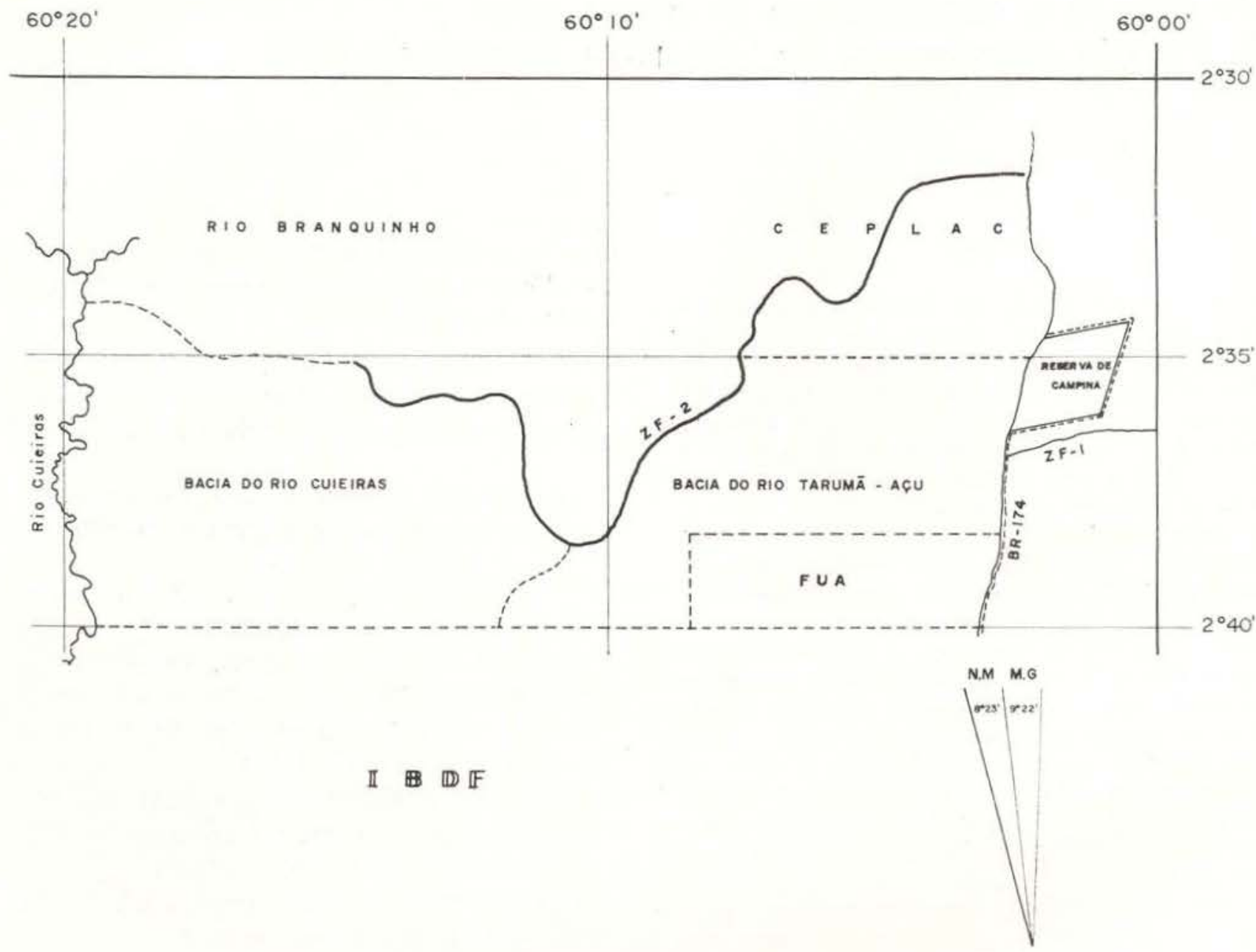

Fig. 1 - Localização e limites da Estação Experimental de Silvicultura Tropical do INPA.

\section{MATERIAL E MÉTODOS}

Com o auxílio de fotografias aéreas na escala de 1:50.000 obtidas pela Cruzeiro do Sul S.A. e da imagem de Radar, folha SA-20ZB do Projeto Radam (1972) na escala de 1:250.000 foi elaborado o mapa base, na escala de 1:50.000. Nesse mapa, foram lançados a rede de drenagem, os limites e confrontações, es. tradas e os trabalhos de campo.

\section{TRABALHO DE CAMPO}

As observações preliminares gerais sobre a distribuição dos solos foram conduzidas por penetrações a pé, depois dum exame cuidadoso dos pares fotográficos com auxílio de um estereoscópio de espelhos Zeiss o qual, reve- lou que, a qualidade e/ou a escala das fotos disponíveis $(1: 50.000)$ não eram adequadas para os propósitos dum levantamento de solos. Assim, não foi possivel distinguir e demarcar por estereoscopia desse material básico as áreas de campina, de campinarana e de mata.

Nos diversos percursos das penetrações orientadas para oeste, com auxílio de bússola Hope foram medidas distâncias com um cordel plástico de $25 \mathrm{~m}$, anotando as variações altimétricas lidas em altímetro Thommen Everest não controlado e fazendo prospecções de solos com auxílio de trado Orchard de 4" dotacio de extensão até 4 metros.

Nas áreas sob experimentação, foram localizados os pontos de abertura das trincheiras com $2 \mathrm{~m}$ de profundidade procedendo-se nes- 
tas o exame morfológico, a coleta de amostras de cada horizonte para fins analíticos, de amostras orientadas para obtenção das secçōes delgadas e de sarrapilheira para estudos microbiológicos.

As picadas de penetração foram feitas apenas marcando passagem por corte de fothas ou galhos de espécies não nobres.

\section{MÉTODOS ANALÍTICOS}

As amostras de terra, uma vez no laboratório, foram secas ao ar e à sombra e preparadas como usualmente, separando por tami. samento a terra fina (TSA) do esqueleto de terra (ET).

A análise mecânica foi feita pelo método da pipeta, empregando como dispersanie o hexametafosfato de sódio (Kilmer \& Alexander, 1940) .

A classificação das partículas por tamanho e as classes texturais foram feitas designando-se os grupos de separados como segue :

$$
\begin{aligned}
& r \ldots \ldots \ldots \text { argila, argiloso (a) } \\
& \text { I } \ldots \ldots \ldots \text { limo, limoso (a) } \\
& \text { a } \ldots \ldots \ldots \text { areia, arenoso (a) } \\
& \text { b } \ldots \ldots \ldots \ldots \text { barro, barrento (a) }
\end{aligned}
$$

A argila natural foi avaliada procedendo-se à dispersão das amostras de terra com água destilada, sem dispersante.

O grau de floculação da argila foi assim obtido :

$$
\frac{\text { argila total }- \text { argila natural }}{\text { argila total }} \times 100
$$

A densidade aparente ( $\mathrm{Da}$ ) foi obtida pelo método da parafina enquanto a densidade rea! (Dr) pelo picnómetro, empregando-se a água destilada. Ambas são referidas $\mathrm{em} \mathrm{g} / \mathrm{cm}^{3}$.

A porosidade total (PT\%) foi avaliada com auxílio da seguinte expressão :

$$
\text { PT\% }=100\left(1-\frac{\mathrm{Da}}{\mathrm{Dr}}\right)
$$

onde: $\mathrm{PT} \%=$ porosidade total em $\%$ de vo lume

$\mathrm{Da}=$ densidade aparente $\mathrm{em} \mathrm{g} / \mathrm{cm}^{3}$

$\mathrm{Dr}=$ densidade real $\mathrm{em} \mathrm{g} / \mathrm{cm}^{3}$.
A capacidade de troca de cátions (CTC) foi avaliada pela soma das bases $(\mathrm{Ca}+\mathrm{Mg}+$ $\mathrm{K}+\mathrm{Na}$ ) extraídas com acetato de amônio $\left(\mathrm{NH}_{4} \mathrm{OAc} \mathrm{N} / 1\right.$ a pH7) mais a acidez de troca extraída com acetato de cálcio $(\mathrm{CaOAc})$.

O cálcio, magnésio, potássio e sódio trocáveis foram determinados no extrato de $\mathrm{NH}_{4} \mathrm{OAc} \mathrm{N} / 1 \mathrm{pH}$, por espectrofotometria de absorção atômica empregando equipamento Perkin Elmer modelo 306 e exprimidos em emg/100g TSE.

O alumínio trocável foi extraido com solu. ção de $\mathrm{KCl} \mathrm{N} / 1$ e determinado colorimetricamente pelo eriocromocianina em fluxo contínuo com equipamento Beckman modelo 25. O alumínio é expresso em emg/100g TSE. obtido :

O grau de saturação em bases foi assim

$$
\mathrm{V} \%=\frac{\mathrm{S} \times 100}{\mathrm{CTC}}
$$

em que: $\mathrm{V} \%=$ grau de saturação em bases

$$
\mathrm{S} \text { = soma das bases trocáveis em }
$$
emg $/ 100 \mathrm{~g}$ TSE

CTC = capacidade de troca de cátions, em emg $/ 100 \mathrm{~g}$ TSE.

O grau de saturação em alumínio trocável foi assim obtido:

$$
\mathrm{V}_{\mathrm{Al}} \%=\frac{\mathrm{Al} \text { trocável } \times 100}{\mathrm{~S}+\mathrm{Al}}
$$

em que: $V_{\mathrm{A} l} \%=$ grau de saturação em alumínio trocável.

$\mathrm{S} \quad=$ soma das bases trocáveis $(\mathrm{Ca}+\mathrm{Mg}+\mathrm{K}+\mathrm{Na}) \mathrm{ex}-$ traídas com o acetato de amônio e expressas em $\mathrm{emg} / 100 \mathrm{~g}$ TSE.

Al = alumínio trocável extraído com $\mathrm{KCIN} / 1$ e expresso em emg $/ 100 \mathrm{~g}$ TSE.

O carbono orgânico foi determinado pelo método de Walkley \& Black (1934), oxidando a materria orgânica com o bicromato de potássio.

O ferro livre foi extraído com ditionito-citrato-bicarbonato (Mehra \& Jackson, 1960) e determinado colorimetricamente segundo Jackson (1958). 
Os fosfatos trocáveis foram obtidos por ex. tração com $\mathrm{H}_{2} \mathrm{SO}_{4} \mathrm{O}, \mathrm{O} 5 \mathrm{~N}$ e dosagem colorimétrica segundo Catani \& Jacintho (1974)

$\mathrm{O} \mathrm{pH}$ em água e em solução de $\mathrm{KCl} \mathrm{N} / 1$ foi obtido para uma relação terra: líquido de 1:1.

O nitrogênio total foi obtido pelo método do micro-Kjehldal.

A umidade nas tensões de $1 / 3$ e de 15 bares foi determinada de acordo com Richards (1954), a partir de curvas de desorção.

$\mathrm{O}$ balanço hídrico e a marcha anual da água disponível de cada solo foram obtidos segundo Thorntwaite \& Mather (1955), adotando as mo. dificações sugeridas por Ranzani (1971) .

A classificação dos solos foi feita pelo sistema proposto em Soil Taxonomy (1975) até o nivel categórico de subgrupo.

$\mathrm{O} \triangle \mathrm{pH}$ foi obtido pela diferença do $\mathrm{pH}$ em água e o $\mathrm{pH}$ em $\mathrm{KCl} \mathrm{N}$ :

$$
\Delta \mathrm{pH}=\mathrm{pH}_{\mathrm{KCl}}-\mathrm{pH}_{\mathrm{H}_{2} \mathrm{O}}
$$

C regime de umidade do solo foi avaliado pelo período de presença de água a tensão inferior a 15 bar e superior a $1 / 3$ bar na seção de controle de cada solo.

A seção de controle da umidade do solo foi avaliada com auxílio das frentes de molhamento das aduções de 25 e $75 \mathrm{~mm}$ de precipitação efetiva em cada solo.

O cueficiente de extensibilidade linear "COLE" foi obtido manipulando pequena porção de amostra dos horizontes a um conteúdo de umidade aproximadamente equivalente à capacidade de campo, medindo o molde após secagem em estufa a $105-110^{\circ} \mathrm{C}$ (Ld) e aplicando a fórmula seguinte :

$$
\operatorname{COLE}=\frac{L m-L d}{L d}
$$

onde $\mathrm{Lm}=$ diâmetro interno da caixa metálica contendo a amostra manipulada e úmida.

O potencial de Extensibilidade Linear (PEL) é representado pela soma dos produtos do Coeficiente de Extensibilidade Linear (COLE) de cada horizonte pela espessura (h) dos horizontes em $\mathrm{cm}$ :

$$
\mathrm{PEL}=\sum(\text { Cole } \mathrm{X} h)
$$

\section{TRABALHO CARTOGRÁFICO}

As coordenadas da área foram avaliadas a partir da imagem de Radar, folha SA-20-ZB (1972) . Obtida a delimitação da área em escala $1: 250.000$, foi ela ampliada, para $1: 50.000$ com auxílio de pantógrafo. Sobre esta carta base foram lançadas as observações de campo e anotações procedidas nas fotografias aéreas

\section{Clima}

A região de Manaus e baixo rio Negro apresenta um clima quente e úmido com precipitações elevadas que tendem a compensar a existência duma estação seca, embora não muito acentuada. Esse clima constitui uma transição entre o super-úmido sem estiagem e o cie duas estaçōes distintas : a chuvosa e a seca.

O tipo climático é $A m$ na classificação de Köppen, o qual além de predominar na bacia Ainazônica se estende para norte pela região da encosta Guianense, para sul pela região da encosta setentrional do Planalto Brasileiro e para leste, pela regiăo da Planície Litorânea. Observa-se que os limites dos tipos climáti$\cos$ da Amazônia brasileira não coincidem com as regiões fisiográficas baseadas nos traços morfológicos.

No Quadro 1, são apresentadas as médias mensais de precipitação segundo Gois Ribeiro (1977), de evapotranspiração segundo o método de Penman modificado (Villa Nova et al., 1976) enquanto as diferenças (P-EP) foram avaliadas a partir dos dados fornecidos por essas fontes.

Como se pode observar, a precipitação anual é de $2478 \mathrm{~mm}$, com a seguinte distribuição pelas estações do ano:

$$
\begin{aligned}
& \text { primavera (SON) ... } 386 \mathrm{~mm} \text { ou } 15,6 \% \\
& \text { verão (DJF) ........ } 783 \mathrm{~mm} \text { ou } 31,6 \% \\
& \text { outono (MAM) ..... } 940 \mathrm{~mm} \text { ou } 37,9 \% \\
& \text { inverno (JJA) } \ldots . \cdots, 369 \mathrm{~mm} \text { ou } 14,9 \% \\
& \text { havendo uma sensível concentração das chu- }
\end{aligned}
$$


QUADRO 1 - Valores médios mensais de precipitação, evapotranspiraçăo, temperatura e P-EP da região cie Manaus segundo Góis Ribeiro (1977) e Villa Nova et al (1976).

\begin{tabular}{l|r|r|r|r|r}
\hline \multicolumn{1}{c|}{ Meses } & $\mathbf{P}(\mathrm{mm})$ & EP (mm) & $\begin{array}{c}\text { Temp } \\
\left({ }^{\circ} \mathbf{C}\right)\end{array}$ & \multicolumn{2}{|c}{$\mathbf{P}-$ EP } \\
\hline Janeiro & 282 & 117 & 25.9 & 165 & - \\
Fevereiro & 279 & 117 & 25.8 & 162 & - \\
Março & 331 & 114 & 25.8 & 217 & - \\
Abril & 314 & 108 & 25.8 & 206 & - \\
Maio & 295 & 117 & 26.4 & 178 & - \\
Junho & 135 & 123 & 26.6 & 12 & - \\
Julho & 138 & 138 & 26.9 & - & - \\
Agosto & 96 & 153 & 27.5 & - & 57 \\
Setembro & 87 & 156 & 27.9 & - & 69 \\
Outubro & 123 & 150 & 27.7 & - & 27 \\
Novembro & 176 & 138 & 27.3 & 38 & - \\
Dezembro & 222 & 123 & 26.7 & 93 & - \\
& & & & & \\
\hline & & & & & \\
Ano & 2478 & 1.554 & 26.7 & +1074 & -153 \\
\hline
\end{tabular}

Verifica-se, através deses dados, que do total de chuvas caídas $1.554 \mathrm{~mm}$ ou $43,7 \%$ são utilizados pela evapotranspiração enquanto $56,3 \%$ ou $1.404 \mathrm{~mm}$ representam perdas por deflúvio, por percolação profunda e por outras formas de destinação da chuva caída e não evapotranspirada.

A temperatura média anual é de $26,7^{\circ} \mathrm{C}$, ocorrendo os seguintes valores médios para as estaçỗes do ano:

$$
\begin{aligned}
& \text { primavera (SON) } \ldots \ldots \ldots \ldots 26,7^{\circ} \mathrm{C} \\
& \text { verão (DJF) } \ldots \ldots \ldots \ldots \ldots, 26,1^{\circ} \mathrm{C} \\
& \text { outono (MAM) } \ldots \ldots \ldots \ldots, 26,0^{\circ} \mathrm{C} \\
& \text { inverno (JJA) } \ldots \ldots \ldots \ldots \ldots, 27,0^{\circ} \mathrm{C}
\end{aligned}
$$

Como se pode observar, existe uma diferença entre as temperaturas médias de verão e de inverno da ordem de $0,9^{\circ} \mathrm{C}$, inferior portanto a $5^{\circ} \mathrm{C}$. Esta diferença e a temperatura média anual de $26,7^{\circ} \mathrm{C}$ caracterizam o regime de temperatura denominado isohipertérmico.

A Fig. 2 mostra o balançc hídrico da região de Manaus. Essa representação mostra o período entre julho e outubro-novembro em que a evapotranspiração potencial é superior à precipitação.

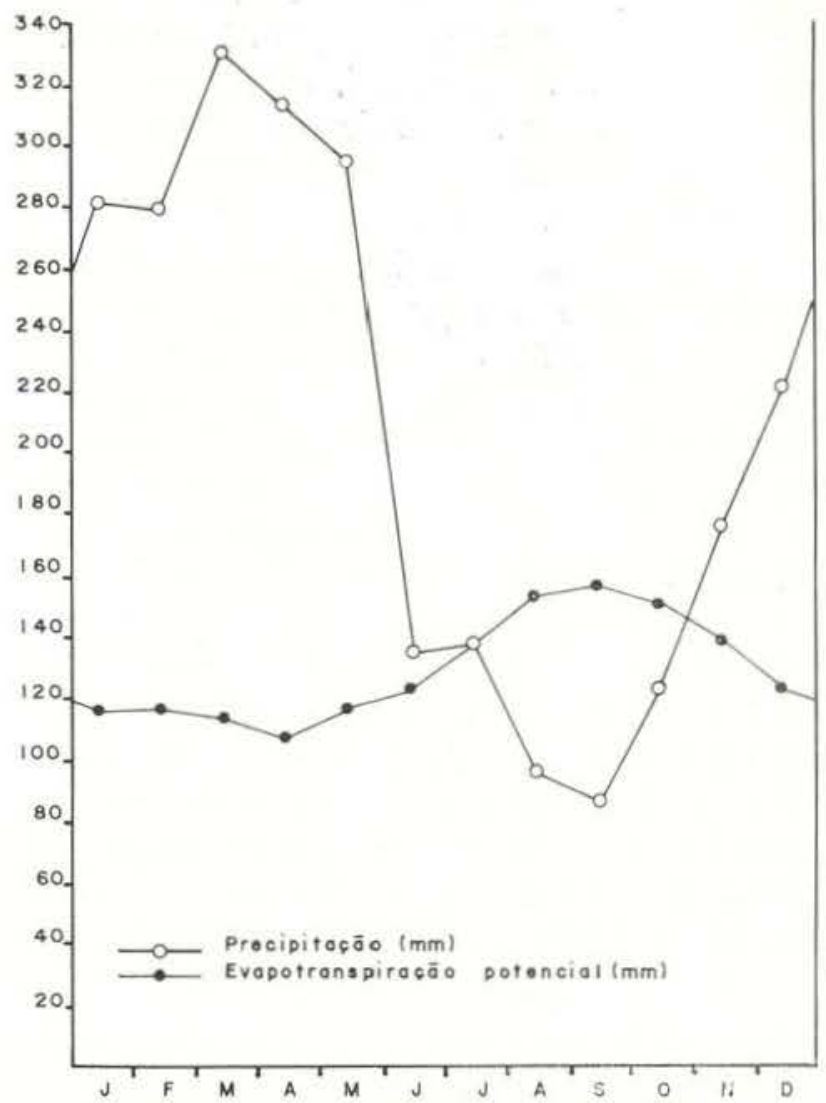

Fig. 2 - Precipitaçäo e Evapotranspiração potencial da regiãc de Manaus segundo Góis Ribeiro (1977) e Villa Nova et al. (1976).

\section{GEOLOGIA}

FORMAÇÃo ALTER DO CHÃo (CRETÁCEO)

Predominam na área os sedimentos da Formação Alter do Chão, do Cretáceo superior. consistindo de arenitos caulínicos, argilitos, grauvacas e brechas intraformacionais. De acordo com Santos et al. (1974), as primeiras referências aos depósitos dessa formação são devidos a Katzer (1898), sendo designados Arenito Manaus por Albuquerque (1922) enquanto Amaral (1954) os atribuiu à série Barreiras. Kistler (1954) parece ter sido o primeiro a empregar para esses depósitos a desig. nação Alter do Chão.

Ainda segundo Santos et al. (1974) baseados em perfurações da Petrobrás, foram assinalados $545 \mathrm{~m}$ de espessura para estes sedimentos no poço de Alter do Chão, alcançando 
$1.250 \mathrm{~m}$ no poço de Almerim. Na região do rio Negro, a espessura da Formação Alter do Chão aumenta de norte para sul, sendo de aproximadamente $100 \mathrm{~m}$ na foz do rio Cuieiras e de $300 \mathrm{~m}$ na altura de Manaus (Sakamoto \& Vargas in Pandolfo, 1959).

Do ponto de vista litológico a Formação Alter do Chão é representada por arenitos argilosos e argilitos com grauvacas e brechas intraformacionais, além de níveis de conglomerados de ocorrência restrita. Os arenitos argilosos são compactos enquanto os argilitos são duros, de coloração avermelhada. Quando alterados perdem a coloração vermelha à semelhança do que ocorre com o arenito Botucatu no Estado de São Paulo (Ranzani et al., 1963): o processo de intemperização se caracteriza pela remoção do cimento sexquioxídico por complexação do ferro com material orgânico proveniente da decomposição de raízes de plantas que sobre $o$ arenito se estabelecem, como é observado na Fig. 3 .

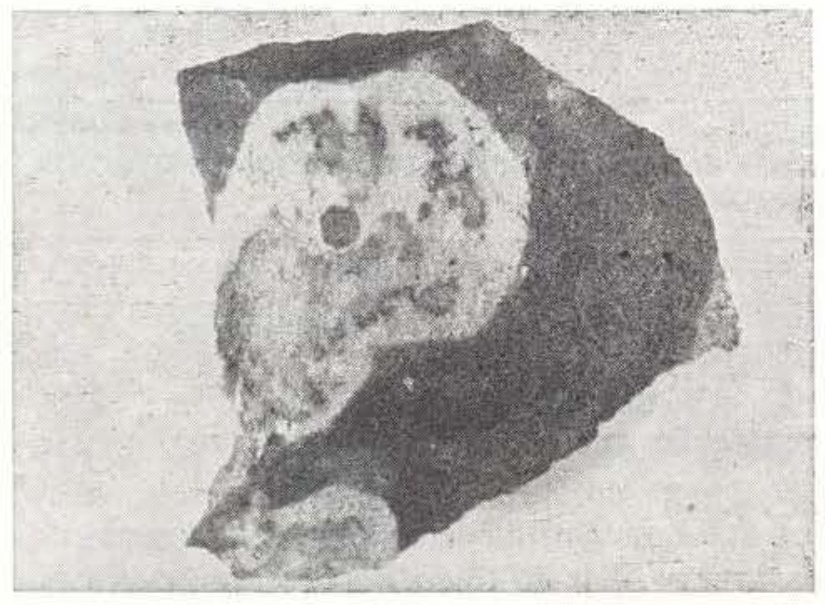

Fig. 3 - Intemperização do arenito Alter do Chão. As raizes se alojam nas fendas e os seus produtos de decomposição reduzem e protegem o ferro que é removido na águas de circulação.

Como resultado dessa complexação e remoção, resulta um material acromático, claro ou branco e menos resistente ao intemperismo, porquanto the falta o cimento sesquioxidico.

As passagens verticais de arenito para argilito são bruscas, o que sugere uma mudan- ça também brusca de condições nos ambientes de sedimentação. As camadas de argilito observadas foram sempre superiores a 2 metros, mostrando um mergulho regional dirigido para sul, sendo afetadas por falhamentos locais.

\section{SEDIMENTOS ARENOSOS (Pleistoceno)}

Consistem de depósitos de areia branca. soltos e profundos, suportando vegetação de campina, cobertos por camada de espessura variável cie um entrelaçado de raízes vivas da esparsa vegetação de campina.

Estes pacotes arenosos com textura mais grosseira em profundiciade, em certas situiações, recobrem um "hardpan" de espessura, características e consistência variáveis, remanescente de um paleossolo. Representa um horizonte Bhir de um podzol que, segundc Heyliggers (1963), provavelmente se formou no interglacial Riss-Würm.

Os sedimentos arenosos recobrindo as diferentes expressões do "hardpan" provavelmente são de origem fluvial, como admitido por alguns autores.

\section{SEDIMENTOS RECENTES (Quaternários)}

Consistem de depósitos vários apresentados ao longo dos cursos d'água sob vegetação "igapó" e consistindo de solos hidromórficos.

\section{RELEVO E DRENAGEM}

A região abrangida pela Estação Experimental de Silvicultura Tropical se caracteriza pela presença de platôs típicos, compondo dois ou provavelmente três níveis altimétricos, sendo menos extenso o nivel mais alto.

A diferença entre o nível das calhas dos cursos d'água, denominados igarapés e a superfície dos platôs que ocorrem no curso médio do rio Tarumã, chega a $70-80 \mathrm{~cm}$.

Penetrações realizadas em 1976, as quais chegaram a $\pm 8 \mathrm{~km}$ a partir da sede da Estação Experimental, seguindo 0 azimute de $287^{\circ} 30^{\prime}$, permitiram obter o que se apresenta na Fig. 4. Esse trajeto, praticamente transversal à rede de drenagem, não apresenta as grandezas altimétricas reais, em virtude de a Estação Experimental não contar com $\mathrm{RN}$ e de 


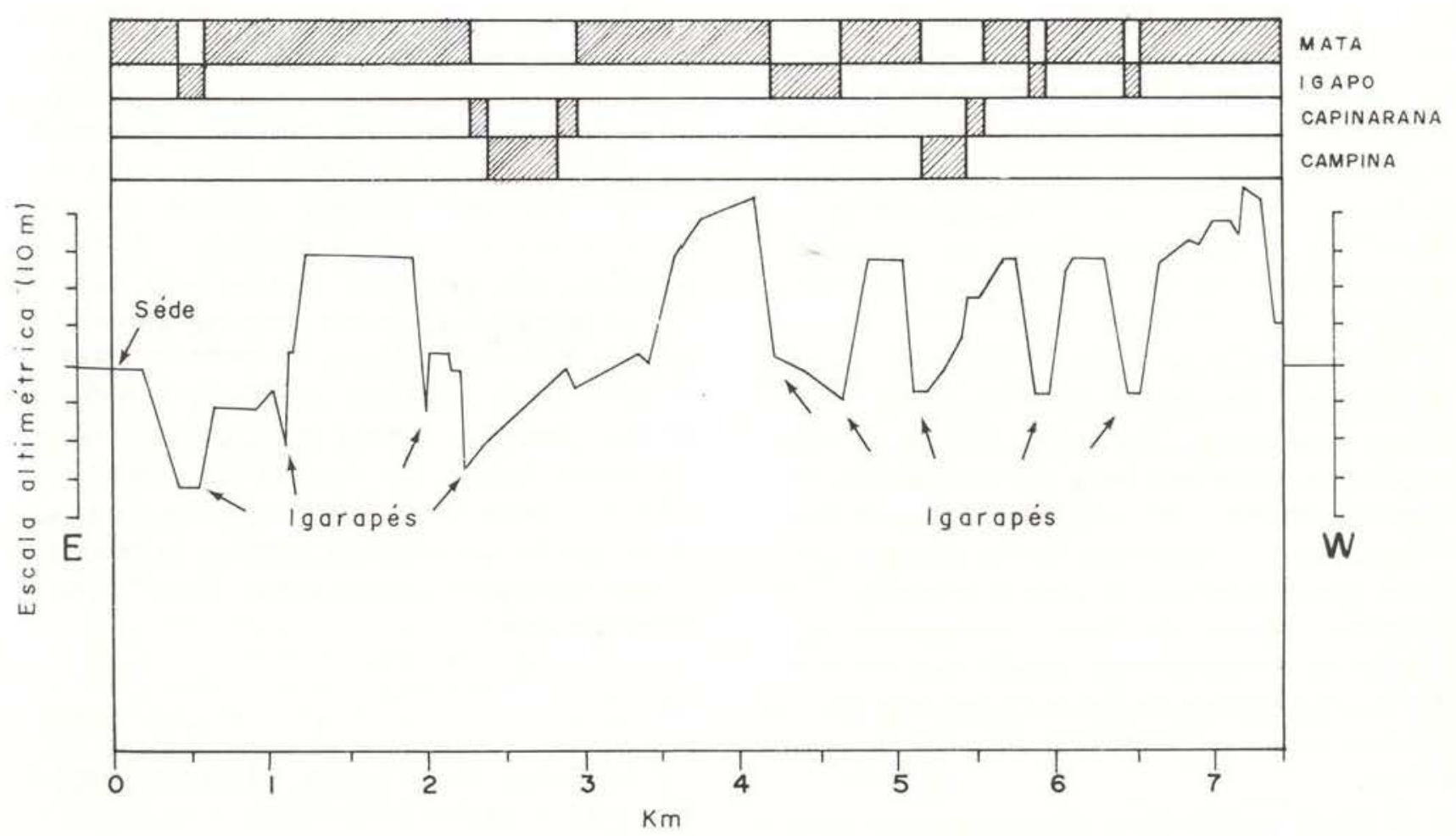

Fig. 4 - Variaçōes altimétricas na área da Estação Experimental de Silvicultura Tropical do INPA, segundo o azimute de $287^{\circ} 30^{\prime}$.

se dispor apenas de altímetro Thommen não aferido. As distâncias horizontais foram obtidas com um cordel plástico de $25 \mathrm{~m}$ e as picadas orientadas por bússola Hope.

A rede de drenagem é do tipo dendritico pouco densa, evidenciando-se o caráter arborescente das cabeceiras d'água, onde em conseqüência, o relevo se acentua mais.

\section{VEGETAÇÃO}

A vista da diversidade de condições oferecidas à colonização vegetal nessa região, é de esperar-se a presença de comunidades vegetais distintas em áreas proporcionadas pelas diversas combinações de solo e de condições de relevo e/ou exposição.

$\mathrm{Na}$ terra firme da Estação Experimental de Silvicultura Tropical do INPA, quatro tipos de vegetação podem ser distinguidos: Campina, Campinarana, Mata Arenícola e Mata Argilicola.

Campina e Campinarana. Os termos "Campina e "Campinarana" são empregados para vegetações baixas sobre solos de areia branca, na terra firme da Amazônia Central. Esses termos são distinguidos pela fisionomia das vegetações que representam. A Campina é uma vegetação esparsa, dominada por arbustos e ervas; a Campinarana é uma mata baixa e densa. Todas as duas são caracterizadas por acumulações de serrapilheira e humus na superfície, onde há uma grande concentração de raízes (com alta ocorrência de micorrhizae). Os estratos dessas vegetações são pouco e facilmente distinguidos; a altura do dossel é variável, atingindo alturas até $12-15 \mathrm{~m}$. São vegetações raquíticas, com ramificação pronunciada e, nos indivíduos maiores, uma tendência de formar copas grandes. As folhas são sempre verdes e mostram características escleromórficas, sendo tipicamente eretas, espessas e pequenas.

Enquanto as epífitas (e.g. orquídeas, bromélias, briófitas e pteridófitas) são extremamente abundantes, outros elementos típicos de florestas tropicais pluviais (e.g. raízes aéreas, sapopemas, cipós e grandes trepadeiras lenhosas) são relativamente ausentes. A campina 
e Campinarana são ambas caracterizadas por uma baixa diversidade de plantas terrestres, e há uma forte tendência para a dominância de poucas espécies. As duas vegetaçōes têm um alto grau de endemismo, com muitas espécies limitadas a tais habitats. Descrições detalhadas dessas vegetaçōes podem ser encontradas em Anderson et al. (1975) e Anderson (1978).

Mata Arenícola e Mata Argilicola. Essas vegetaçôes ocorrem sobre latossolos com conteúdos variáveis de argila. Ambas são caracterizadas por uma falta de acumulação de humus; uma estrutura complexa, com estratos dificilmente distinguíveis; folhas sempre verdes e mesofíticas; uma presença notável de elementos típicos de florestas tropicais pluviais (e.g. raízes aéreas, sapopemas, cipós e grandes trepadeiras lenhosas); uma alta diversidade e uma abundância de espécies cosmopolitas.

A Mata Arenícola é distinguida por uma estrutura relativamente reduzida: o dossel atinge alturas de aproximadamente $12-20 \mathrm{~m}$, com emergentes ocasionais de $25 \mathrm{~m}$. Há uma abundância de árvores com copas pequenas e caules finos; em um hectare desta vegetação, ocorrem aproximadamente 2.500 árvores com diâmetros $\geq 5,0 \mathrm{~cm}$. A alta densidade de árvores relativamente pequenas deixa penetrar uma abundância de luz, e os estratos inferiores são densamente ocupados por palmeiras $\mathrm{e}$ ervas, tais como Marantáceas e Ciclantáceas. Como conseqüência, esta vegetação torna-se difícil de penetrar. O chão é caracterizado por uma manta grossa de raízes, sobre a qual ocorrem acumulações de serrapilheira; essas duas camadas produzem uma qualidade distintamente fofa. Embora possuindo uma diversidade alta, a Mata Arenícoia é caracterizada por uma dominância pronunciada de certas faixas, tais como Protium spp, Swartzia spp e Licania spp nos estratos superiores, e Rhabdodendron macrophyllum e Theobroma silves. tre nos estratos inferiores.

A Mata Argilícola é distinguida por uma estrutura relativamente grande: o dossel atinge alturas de aproximadamente $18-30 \mathrm{~m}$, com emergentes de $30-35 \mathrm{~m}$. Em comparação com a Mata Arenícola, há relativamente menos árvores com caules finos e a densidade total é menor: em um hectare, ocorrem aproximadamente 1.500 árvores com diâmetros $\geq 5,0 \mathrm{~cm}$. A abundância de árvores maiores, com copas espalhadas, diminui a penetração de luz; como conseqüência, os estratos inferiores são relativamente abertos, tornando esta vegetação fácil de penetrar. O chão é caracterizado por uma manta mais fina de raizes e há pouca acumulação de serrapilheira. Na Reserva Biológica do INPA/SUFRAMA, a diversidade da Mata Argilícola é extremamente grande e o grau de dominância extremamente baixo. Em termos de composição florística, esta vegetação pode ser caracterizada apenas ao nível d'e família, as mais importantes sendo Leguminosas. Sapotáceas e Lecytidáceas .

\section{SoLos}

Os locais onde foram feitas as trincheiras para o exame morfológico e a coleta de amostras dos perfis de solos são indicados na Fig. 5.

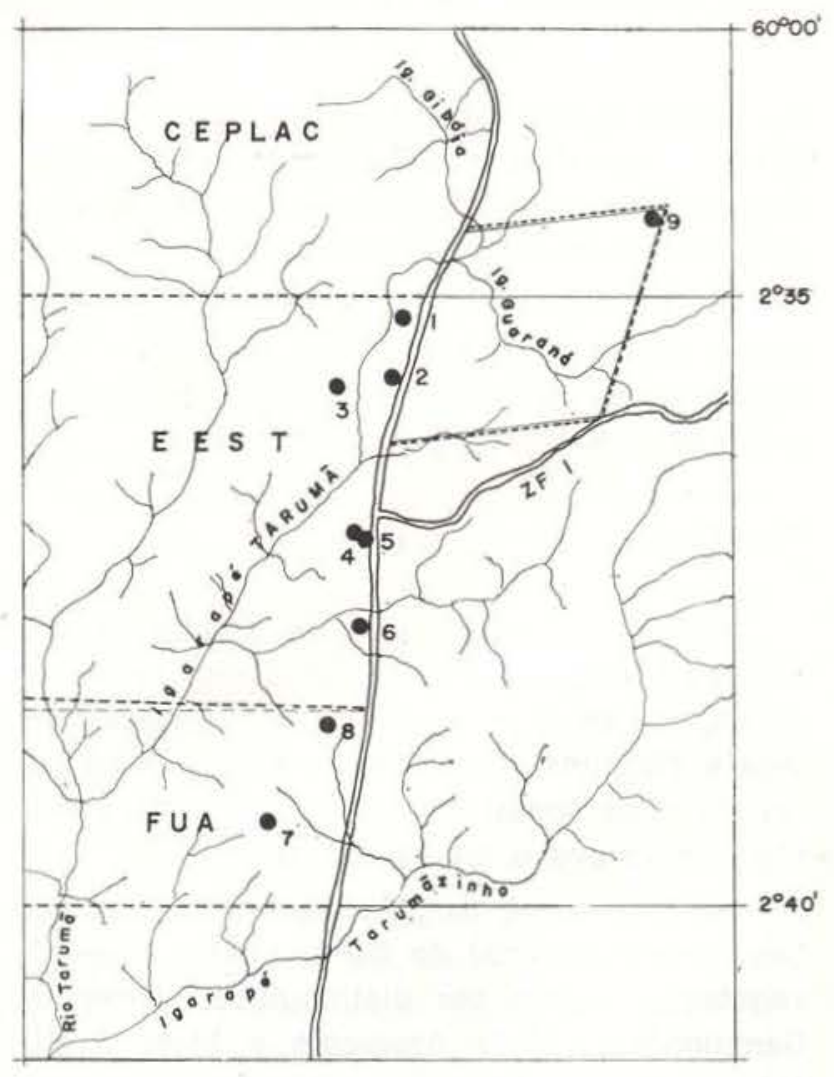

Fig. 5 - Localização dos perfis de solo na Estação Experimental de Silvicultura Tropical do INPA. 
PERFIL EFST-1

DATA: $27.07-1977$

Morfologia do Perfil EEST-1

CLASSIFICAÇÃO: ORTHOXIC TROPOHUMULT PODZOLICO VERMELHO, AMARELO, álico, Latossólico, A moderado, textura média.

LOCALIZAÇĀO: Roçado da Mata arenícola, a $1050 \mathrm{~m}$ a $\mathrm{N}$ da sede da Reserva, lado esquerdo da BR-174 penetrando $100 \mathrm{~m} W$ e $100 \mathrm{~m}$ $180^{\circ} \mathrm{S}$.

GEOLOGIA: Sedimentos fluviais sobre a Formação Alter-do-Chăo.

MATERIAL DE ORIGEM: Sedimentos arenosos não consolidados.

RELEVO LOCAL: Plano.

RELEVO REGIONAL: Suave ondulado.

VEGETAÇAOO: Desmatamento de Mata arenicola e queima; experimento de Jacareúba, Pau-Balsa, Marupá, Sumaúma, Cumarú, Berlinga, Paricá, Cardeiro e Morototó.

DRENAGEM: Boa,

EROSÃO: Ausente.

USO ATUAL: Area experimental.

MORFOLOGIA:

$A_{11} \quad 0-25 \mathrm{~cm}$; matriz pardo amarelado (10YR5/4; 4/4 úmido) com eflorescências de areia lavada, comuns; barro argilo arenoso; gräos simples solto muito friável, nāo plástico, nāo pegajoso; raizes finas e muito finas comuns; galerias biológicas pequenas e médias comuns; macroporos abundantes; acumulaçōes de material orgânico (N2/) pouco: limite suave, gradual.

A $_{12} 25-60 \mathrm{~cm}$; matriz pardo amarelado (10YR5/6: $4 / 3$ úmido) com $40 \%$ de áreas irregulares pardo amarelado claro $(10 \mathrm{YR} 6 / 4)$ pouco nitidas, pequenas; areia; maciço: macio, muito friável, não plástico, não pegajoso; raízes finas e médias pouco; galerias biológicas pequenas e médias comuns: macroporos abundantes; limite suave, gradual a claro.

$\mathrm{A}_{3} / \mathrm{B}_{1} 60-88 \mathrm{~cm}$; matriz pardo muito pálido (10YR7/3: 6/6 úmido) com apenas áreas amarelo pardacentas $(10 \mathrm{YR} 6 / 6)$ e pardo amarelado escu. ro (10YR4/4) pouco nítidas, comuns; barro argilo arenoso; maciço; ligeiramente duro. muito friável, ligeiramente plástico, pegajoso: raízes médias pouco; galerias biológicas pequenas e médias abundantes; macroporos comuns; esqueleto de quartzo até $0.5-1 \mathrm{~cm}$. pouco, limite suave, gradual.

$\mathrm{B}_{21} \quad 88-120 \mathrm{~cm}$; matriz róseo $(7,5 \mathrm{YR} 7 / 4 ; 6 / 8$ úmido) com pequenas pontuaçōes brancas, pouco nitidas, comuns; barro argilo arenoso; maciço; duro, muito friável, plástico, pegajoso: raízes médias e pequenas abundantes; macroporos comuns; fragmentos de quartzo irregulares parcialmente arredonda- das $(0,5-1 \mathrm{~cm})$ comuns; limite suave, difuso.

$\mathrm{B}_{n} 120$ - $172 \mathrm{~cm}$; matriz róseo (7,5YR7/4; 6/6 úmido) com $30 \%$ de áreas irregulares amarelo avermelhado (7,5YR6/8 úmido) pouco nítidas e que desaparecem quando secas; barro argilo arenoso: maciço; duro, muito friável, plástico, pegajoso; raizes muito finas pouco; galerias biológicas pequenas comuns; macroporos comuns; esqueleto de quartzo irregular pequeno, comum; limite suave, difuso.

B $175-260 \mathrm{~cm}$; matriz branco rosado $(7,5$ YR8 $/ 2 ; 6 / 6$ úmido) com áreas róseo (7,5YR8/4 úmido) pouco nítidas em $20 \%$; barro argilo arenoso; maciço; duro a ligeiramente duro, muito friável, ligeiramente plástico, pegajoso; galerias

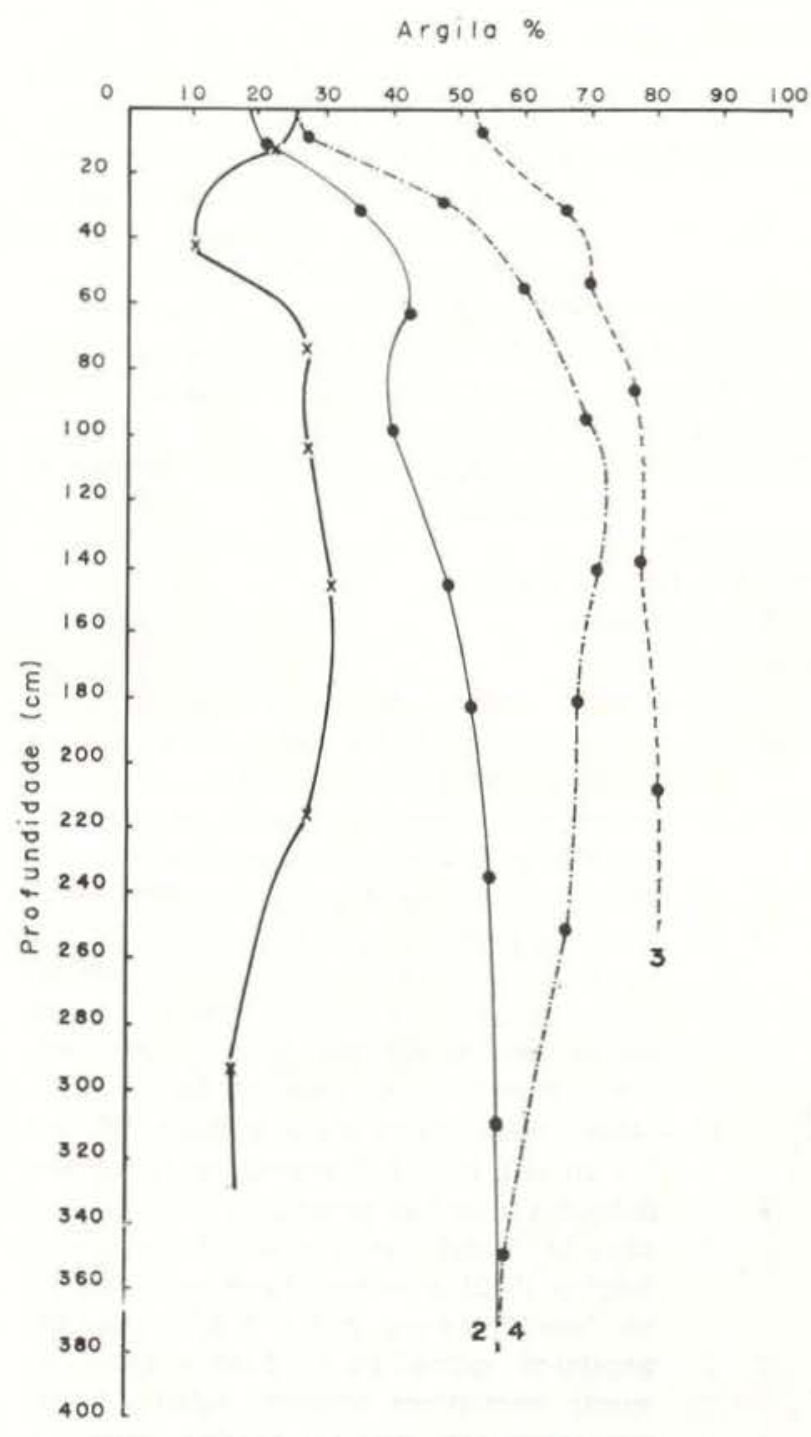

Fig. 6 - Distribuição da argila em função da profundidade nos perfís EEST - 1, 2, 3 e 4 . 
biológicas pequenas e médias comuns; esqueleto de quartzo pouco.

C $260-330+\mathrm{cm}$; matriz branco a branco rosado (7,5YR8/ $-8 / 2 ; 7 / 4$ úmido) com $50 \%$ branco em pequenas áreas, nítidas; barro arenoso; maciço; ligeiramente duro a solto, muito friável, ligeiramente plástico, ligeıramente pegajoso; esqueleto de quartzo pouco. OBS.: Amostragens do horizonte $\mathrm{C}$ foram obtidas por tradagem.

\section{Resultados analíticos do Perfil EEST-1}

Estes resultados são apresentados no Quadro 2.

PERFIL EEST - 2

DATA: 28.07.1977

\section{Morfologia do Perfil EES1-2}

\section{CLASSIFICAÇÃO: TYPIC PALEUDULT} PODZÓLICO VERMELHO AMARELO álico, A moderado, textura argilosa.

LOCALIZAÇÃO: meia encosta de elevação que separa o Alojamento do Refeitório da Estação Experimental de Silvicultura Tropical, no Km 45 da Rodovia BR-174.

GEOLOGIA: Formação Alter-do-Chão.

MATERIAL DE ORIGEM: Sedimentos argilo-arenosos. RELEVO LOCAL: Suave ondulado; declividade $5 \%$.

RELEVO REGIONAL: Suave ondulado.

VEGETAÇÃO: Mata argilícola, parcialmente desmatada com queima.

DRENAGEM: Boa,

EROSAO: Laminar ligeira.

USO ATUAL: Mata.

MORFOLOGIA:

$A_{11} \quad 0-17 \mathrm{~cm} ;$ matriz pardo amareiado claro (10YR6/4; $5 / 3$ úmido) com áreas médias pardo escuro (10YR3/3 úmido) e (N2/) de acumulaçōes orgânicas; barro argilo arenoso; maciço que se rompe em fragmentos irregulares e granular pequena a média, fra$\mathrm{co}$; esqueleto de quartzo comum; ligeiramente duro a duro, muito friável, ligeiramente plástico, pegajoso; raízes grossas pouco, médias e finas comuns; macroporos comuns; limite suave, gradual.

$\mathrm{A}_{12} \quad 17-45 \mathrm{~cm}$; matriz pardo muito pálido (10YR7/3; 6/4 úmido), (10YR6/3 amassado), com áreas pequenas a médias pardo (10YR5/3) de acumulações orgânicas pouco nítidas e pontuações (N/2) esparsas; barro argilo arenoso; maciço; duro, muito friável, plástico, pegajoso; raízes muito finas e finas comuns; macroporos comuns; galerias biológicas pequenas, comuns; carvōes esparsos: limite suave, gradual.

$\mathrm{A}_{3} / \mathrm{B}_{1} 45-72 \mathrm{~cm}$; matriz róseo $(7,5 Y \mathrm{YR} 7 / 4 ; 6 / 6$ úmido $)$ $\operatorname{ccm} 30 \%$ de acumulações orgânicas pardo amarelado claro (10YR6/4) e carvões (N2/) esparsos pouco; argila arenosa; maciço que se rompe em blocos sub-angulares, fraco; duro, muito friável, plástico, muito pegajoso; galerias biológicas pequenas, comuns; macroporos alongados semelhantes a uma clivagem irregular por secagem, abundantes; cerosidade (?) ou superfícies de pressão comuns; raizes muito finas pouco; carvões pouco; limite suave, gradual.

$\mathrm{B}_{21} \quad 72-122 \mathrm{~cm}$; matriz róseo $(7,5 Y \mathrm{Y} 7 / 4 ; 7 / 6$ úmido $)$ com galerias biológicas cheias com deposições cinza pardacento claro (10YR6/2) nítido, comum; argila arenosa; maciço que se rompe em fragmentos médios a grandes; duro, muito friável, plástico, muito pegajoso; raízes muito finas pouco; galerias biológicas pequenas, comuns; macroporos de secção irregular assemelhando-se a pe-

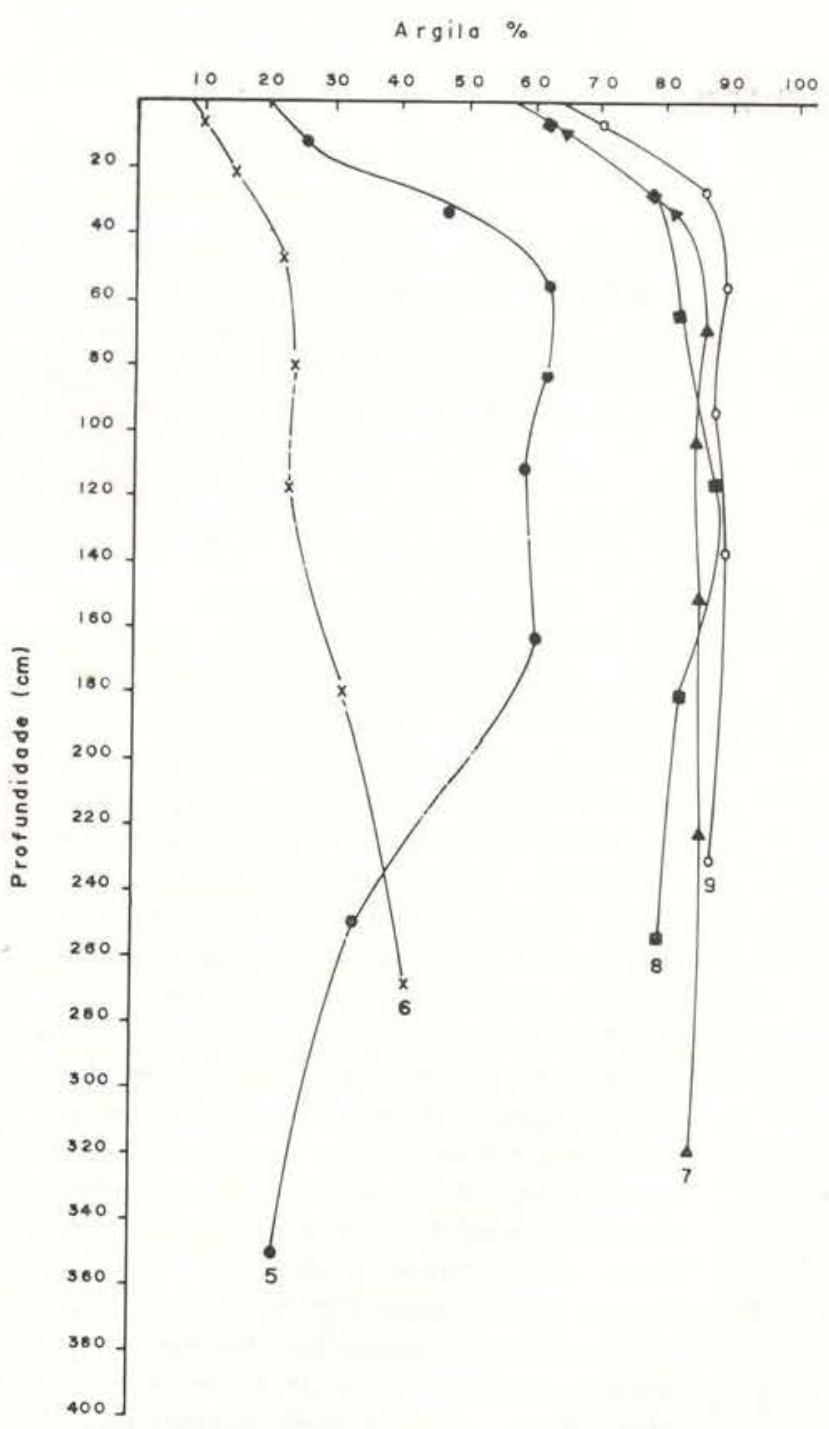

Fig. 7 - Distribuição da argila em função da profundidade nos perfís EEST - 5, 6, 7, 8 e 9 . 


\section{QUADRO 2}

\begin{tabular}{|c|c|c|c|c|c|c|c|c|c|c|c|c|c|c|c|c|c|}
\hline \multicolumn{15}{|c|}{$\begin{array}{l}\text { PERFIL EEST-1 } \\
\text { Amostras de Lab. n.0 } 17 \text { a } 23\end{array}$} & \multicolumn{3}{|c|}{ DCA - Dept.o Solos } \\
\hline \multicolumn{2}{|c|}{ HORIZONTES } & \multirow{2}{*}{$\begin{array}{c}\text { Calhóu } \\
>20 \\
\text { mm } \\
\%\end{array}$} & \multirow{2}{*}{$\begin{array}{c}\text { Coscalho } \\
2-20 \\
m m \\
\%\end{array}$} & \multirow{2}{*}{$\begin{array}{c}\text { Terro } \\
\text { fina } \\
<2 \\
\mathbf{m m} \\
\%\end{array}$} & \multicolumn{3}{|c|}{ ANÁLISE } & \multicolumn{2}{|c|}{$M E C A N I C A$} & \multicolumn{2}{|l|}{$\%$} & \multirow{2}{*}{$\begin{array}{c}\text { Argila } \\
\text { Dispersa } \\
\text { em } \\
\text { agua \% }\end{array}$} & \multicolumn{2}{|c|}{ DENSIDADES } & \multirow{2}{*}{$\begin{array}{l}c_{\text {ern }} \\
\%\end{array}$} & \multirow{2}{*}{$\begin{array}{l}\mathrm{N} \\
\%\end{array}$} & \multirow[b]{2}{*}{$\mathrm{C} / \mathrm{N}$} \\
\hline Design. & $\begin{array}{l}\text { Prot. } \\
\text { (cm) }\end{array}$ & & & & $\begin{array}{l}\text { Areia } \\
\text { muito } \\
\text { grossa } \\
2-1\end{array}$ & $\begin{array}{l}\text { Areia } \\
\text { grossa } \\
1-0,5\end{array}$ & $\begin{array}{c}\text { Areia } \\
\text { média } \\
0,5-0,25\end{array}$ & $\begin{array}{c}\text { Areia } \\
\text { fina } \\
0,25-0,10\end{array}$ & $\begin{array}{c}\begin{array}{c}\text { Areia } \\
\text { muito } \\
\text { fino } \\
0,10-0,05\end{array} \\
\end{array}$ & $\begin{array}{l}\text { Limo } \\
0,05 \\
0,002\end{array}$ & $\underset{0,002}{\text { Argila }}$ & & $\begin{array}{l}\text { Aporente } \\
\mathrm{g} / \mathrm{cm}^{3}\end{array}$ & $\begin{array}{c}\text { Real } \\
\mathrm{g} / \mathrm{cm}^{3}\end{array}$ & & & \\
\hline A11 & $0-25$ & & 1,0 & 99,0 & 4,0 & 23,5 & 38.1 & 8,8 & 1,0 & 2,3 & 22,3 & 18,6 & 1,40 & 2,66 & 1,8 & 0,08 & 22 \\
\hline A12 & $25-60$ & & 0,1 & 99,9 & 1,2 & 16,2 & 50,1 & 19,2 & 1,6 & 1,9 & 9,8 & 6,2 & 1,36 & 2,69 & 2,0 & 0,11 & 18 \\
\hline A3 & $60-88$ & & 0.4 & 99,6 & 2,9 . & 17,1 & 32,4 & 13,1 & 3,3 & 4,2 & 27,0 & 22,8 & 1,47 & 2,56 & 0,8 & 0,04 & 20 \\
\hline B21 & $88-120$ & & 1,2 & 98,8 & 3,2 & 17,9 & 32,6 & 16,2 & 1,7 & 2,7 & 25,7 & 2,2 & 1,52 & 2,75 & 0.4 & 0,06 & 6 \\
\hline B22 & $120-172$ & & 3,3 & 96,7 & 1,0 & 13,5 & 36,2 & 13,8 & 1,3 & 3,6 & 30,6 & 0,7 & 1,55 & 2,68 & 0,3 & 0,05 & 6 \\
\hline B3 & $172-260$ & & 1,3 & 98,7 & 3,6 & 13,1 & 25,6 & 19,8 & 2,6 & 7,8 & 27,5 & 0,6 & 1,52 & 2,59 & 0,1 & 0,05 & 2 \\
\hline C & $260-330+$ & & 2,7 & 97,3 & 14,0 & 26,1 & 25,9 & 11,3 & 1,2 & 4,4 & 17,1 & 1,2 & 1,52 & 2,68 & - & 0,12 & \\
\hline
\end{tabular}

\begin{tabular}{|c|c|c|c|c|c|c|c|c|c|c|c|c|c|c|c|}
\hline \multirow{2}{*}{$\begin{array}{c}\text { с T C } \\
\text { emg } \\
\%\end{array}$} & \multicolumn{5}{|c|}{$\begin{array}{c}\text { IONS TROCAVEIS } \\
\text { emg } \%\end{array}$} & \multicolumn{2}{|c|}{$\begin{array}{c}\text { ACIDEZ TROCÁVEL } \\
\text { e m g \% }\end{array}$} & \multirow{2}{*}{$\begin{array}{c}\text { Volor } \\
s\end{array}$} & \multirow{2}{*}{$\begin{array}{l}\text { Volor } \\
\text { v\% }\end{array}$} & \multicolumn{2}{|c|}{ PH $(1: 1)$} & \multicolumn{3}{|c|}{ UMIDADE/TENSÖES } & \multirow{2}{*}{$\begin{array}{l}100 \mathrm{Al} \\
\mathrm{Al}+\mathrm{S}\end{array}$} \\
\hline & $\mathrm{ca}$ & $\mathrm{Mg}$ & K & $\mathrm{No}$ & $\mathrm{PO}_{4}$ & H & AI & & & $\mathrm{H}_{2} \mathrm{O}$ & $\mathrm{KC}(\mathrm{N}$ & $\begin{array}{l}1 / 10 \\
\text { ot } m\end{array}$ & $\begin{array}{l}1 / 3 \\
a+m\end{array}$ & $\begin{array}{c}15 \\
\text { of } m\end{array}$ & \\
\hline 3,61 & 0,13 & 0,03 & 0,04 & 0,05 & 0,02 & & 0,82 & 025 & 7 & 4,2 & 4,0 & & 13.0 & 10.2 & 77 \\
\hline 2,65 & 0,13 & 0,07 & 0,03 & 0,06 & 0,04 & & 0.57 & 0,29 & 8 & 4,0 & 3,6 & & 5.2 & 2.9 & 66 \\
\hline 2,13 & 0.13 & 0,04 & 0,04 & 0,04 & 0,01 & & 0.48 & 0,25 & 12 & 4,2 & 4,0 & & 13.7 & 9.0 & 66 \\
\hline 1,59 & 0,19 & 0,05 & 0,01 & 0,06 & 0,01 & & 0,29 & 0,31 & 19 & 4,2 & 4,0 & & 12.5 & 8.6 & 48 \\
\hline 1.14 & 0,16 & 0,04 & 0,01 & 0,05 & 0,01 & & 0.48 & 0.26 & 23 & 4,1 & 4,1 & & 14.4 & 10.5 & 65 \\
\hline 0.51 & 0,13 & 0.02 & 0,01 & 0,05 & 0,01 & & 0,41 & 0,21 & 41 & 4.0 & 4,0 & & 13.8 & 8.5 & 66 \\
\hline 1,05 & 0,17 & 0.02 & 0,01 & 0,05 & 0,01 & & 0.27 & 0,25 & 26 & 4,1 & 4.1 & & 9.9 & 6.1 & 52 \\
\hline
\end{tabular}


quenas clivagens, comuns; cerosidade (?) ou superfícies de pressão, comuns; carvṍs pequenos, esparsos; limite suave, difuso.

$\mathrm{B}_{22} \quad 122-166 \mathrm{~cm}$; róseo $(7,5 \mathrm{YR} 7 / 4 ; 7 / 6$ úmido); argila arenosa; maciço que se rompe em blo. $\cos$ e microagregados, fraco; duro, muito friável, plástico, muito pegajoso; raízes finas pouco; galerias biológicas pequenas, pouco; macroporos deformados com secções alongadas semelhantes a planos de clivagem irregulares, comuns; cerosidade (?) ou superfícies de pressão, pouco; carvões pequenos pouco; limite suave, difuso

$\mathrm{B}_{3} \quad 166-200 \mathrm{~cm}$; róseo (7,5YR7/4; $7 / 6$ úmido); argi. la; maciço; duro, muito friável, plástico, pe gajoso; raízes muito finas pouco; galerıas biológicas pequenas pouco; macroporos se. melhantes a pequenas fraturas, pouco; limite suave, difuso.

C $\quad 200-265 \mathrm{~cm}$; matriz róseo $(7,5 \mathrm{YR} 7 / 4 ; 7 / 6$ úmido) com $30 \%$ de pontuaçōes reunidas em pe quenas áreas pardo muito pálido (10YR8/4); argila; maciço; duro, muito friável, plástico, muito pegajoso; raizes muito finas pouco; macroporos semelhantes a pequenas fraturas, comuns.

$\mathrm{C}_{2} \quad 265-380+\mathrm{cm}$; róseo $(7,5$ YR8 $/ 4 ; 3 / 6$ úmido $)$; argila; maciço; duro, muito friável, plástico, pegajoso.

OBS.: As amostragens a partir de $200 \mathrm{~cm}$ foram obtidas por tradagem.

Resultados analíticos do Perfil EEST-2

Estes resultados são apresentados no Quadro 3.

PERFIL EEST - 3

\section{Morfologia do Perfil EEST-3}

DATA: 28.07 .1977

CLASSIFICAÇÃO: ORTHOXIC PALEHUMULT PODZÓLICO VERMELHO AMARELO álico, Latossólico, A moderado, textura argilosa.

LOCALIZAÇĀO: Campo $\left(\mathrm{A}_{2}\right)$ de Ensaios com Espécies Florestais; experimento de Fenologia, situado na parte SW da área da Esta. ção Experimental de Silvicultura Tropical, lado esquerdo da BR-174, vertente direita do igarapé Tarumã-açu.

GEOLOGIA: Formação Alter-do-Chão.

MATERIAL DE ORIGEM: Sedimentos argilosos.

RELEVO LOCAL: Suave ondulado a ondulado durto.

RELEVO REGIONAL: Ondulado a suave ondulado.

DRENAGEM: Moderada a boa.

VEGETAÇÃO: Mata argilícola, broqueada sem queima. EROSĀO: Laminar severa.

USO ATUAL: Experimentaçåo com Sumaúma, Belinga, Pau-Balsa, Paricá, Cumaru, Caroba, Maru-

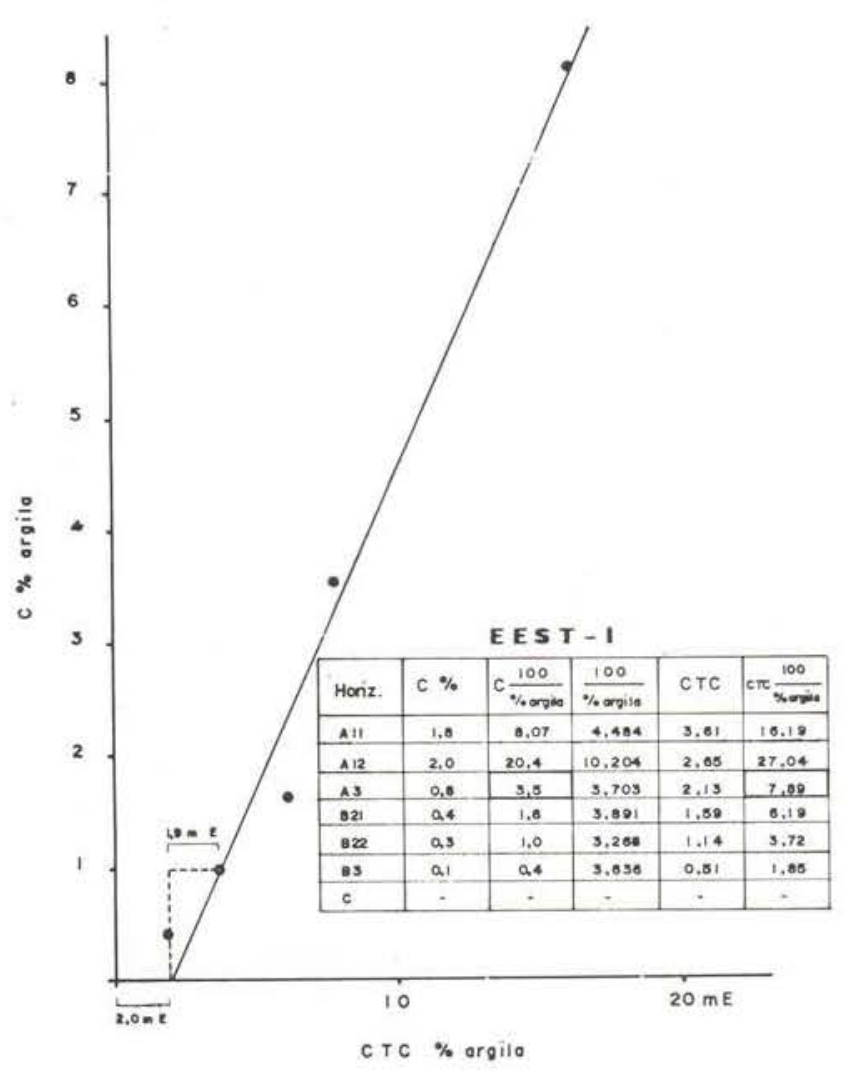

Fig. 8 - Relação C e CTC para $100 \mathrm{~g}$ de argila (segundo Bennema/1966) correspondente ao perfil EEST-1.

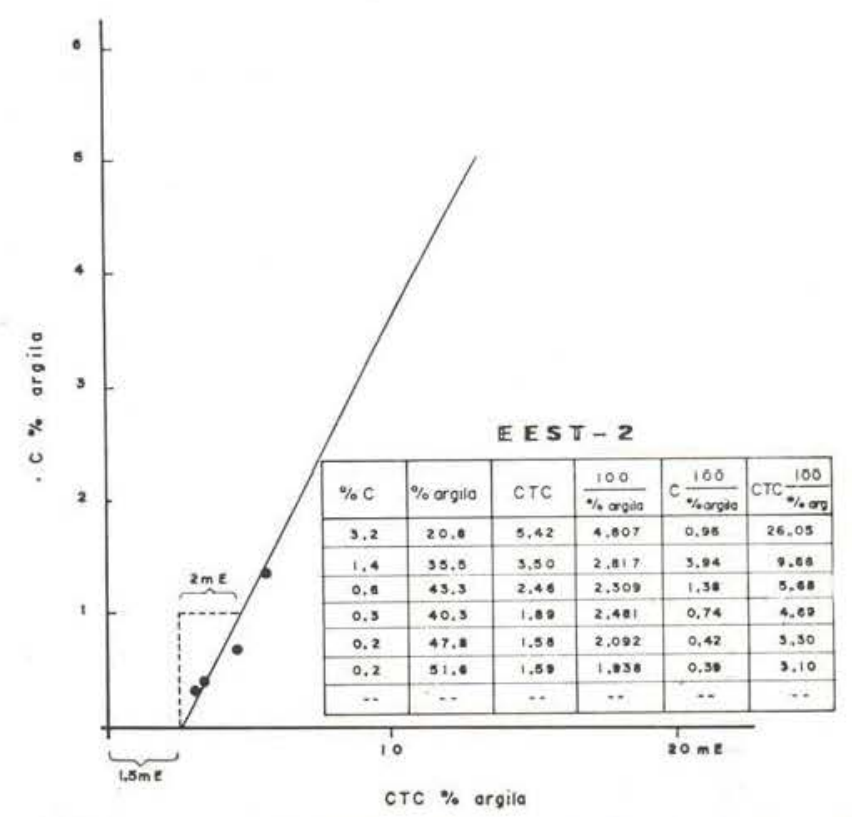

Fig. 9 - Relação C e CTC para $100 \mathrm{~g}$ de argila (segundo Bennema, 1966) correspondente ao perfil EEST-2. 
QUADRO 3

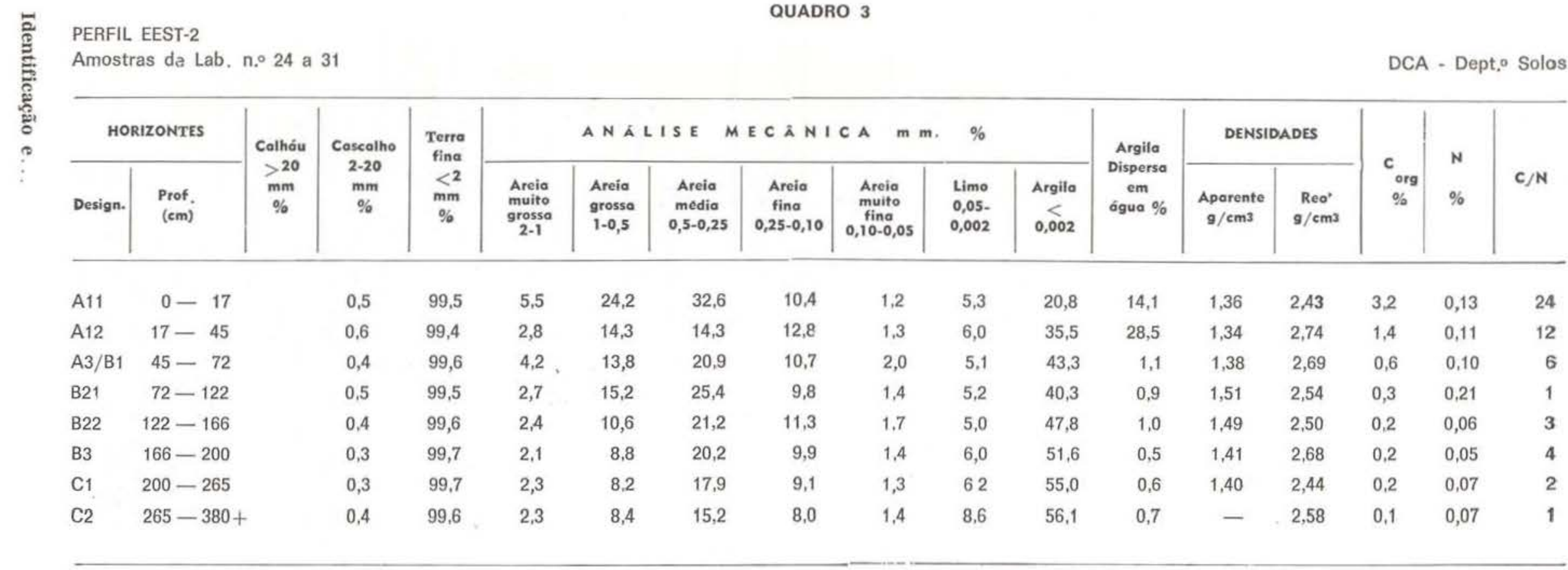

\begin{tabular}{|c|c|c|c|c|c|c|c|c|c|c|c|c|c|c|c|}
\hline \multirow{2}{*}{$\begin{array}{l}\text { c тc } \\
\text { e m g } \\
\%\end{array}$} & \multicolumn{5}{|c|}{$\begin{array}{c}\text { IONS TROCAVEIS } \\
\text { emg \% }\end{array}$} & \multicolumn{2}{|c|}{$\begin{array}{l}\text { ACIDEZ TROĆ́̄VEL } \\
\text { e m g \% } \\
\end{array}$} & \multirow{2}{*}{$\begin{array}{c}\text { Volor } \\
\text { s }\end{array}$} & \multirow{2}{*}{$\begin{array}{l}\text { Valor } \\
\text { v\% }\end{array}$} & \multicolumn{2}{|c|}{ PH $(1: 1)$} & \multicolumn{3}{|c|}{ UMIDADE/TENSÖES } & \multirow{2}{*}{$\begin{array}{l}100 \mathrm{Al} \\
\mathrm{Al}+\mathrm{S}\end{array}$} \\
\hline & $\mathrm{Ca}$ & $\mathrm{Mg}$ & K & $\mathrm{Na}$ & $\mathrm{FO}_{4}$ & H & Al & & & $\mathrm{H}_{2} \mathrm{O}$ & $\mathrm{KC}(\mathrm{N}$ & $\begin{array}{l}1 / 10 \\
\text { ot } m\end{array}$ & $\begin{array}{l}1 / 3 \\
\text { ot } m\end{array}$ & $\begin{array}{c}15 \\
\text { of } m\end{array}$ & \\
\hline 5,42 & 0,13 & 0,09 & 0,07 & 0,07 & 0,04 & & 1,26 & 0,36 & 6 & 4,0 & 3,4 & & 11.6 & 8.1 & 78 \\
\hline 3,50 & 0,12 & 0,04 & 0,02 & 0,04 & 0,02 & & 1,00 & 0,22 & 6 & 4,1 & 4,0 & & 17.9 & 12.9 & 82 \\
\hline 2,46 & 0,12 & 0,03 & 0,01 & 0,06 & 0,02 & & 0,77 & 0,22 & 9 & 4,0 & 3,9 & & 18.5 & 14.7 & 78 \\
\hline 1,89 & 0,19 & 0,03 & 0,02 & 0,07 & 0.02 & & 0,63 & 0,31 & 16 & 3,9 & 3,9 & & 18.7 & 16.0 & 67 \\
\hline 1,58 & 0.10 & 0,02 & - & 0,04 & 0,01 & & 0,65 & 0,16 & 4 & 4,0 & 4,0 & & 20.4 & 14.2 & 40 \\
\hline 1,59 & 0,22 & 0,02 & - & 0,05 & 0,01 & & 0,66 & 0,29 & 18 & 4,0 & 4,0 & & 23.2 & 20.0 & 69 \\
\hline 1,49 & 0,14 & 0,03 & 0,01 & 0.07 & 0,01 & & 0,67 & 0.25 & 17 & 4,1 & 4,1 & & 25.9 & 21.8 & 73 \\
\hline 1,63 & 0,11 & 0,02 & - & 0,06 & 0,01 & & 0,38 & 0,19 & 12 & 4.6 & 4,2 & & 27.5 & 21.9 & 67 \\
\hline
\end{tabular}


pá, Tatajuba, Envira Surucucu, Pau-Rosa, Cedro, Morototó, Framiré.

MORFOLOGIA:

$A_{11} \quad 0-12 \mathrm{~cm}$; matriz pardo muito pálido (10YR7/2; 6/3 úmido), (10YR7/4 amassado) com áreas irregulares pardo pálido (10YR6/3) devidas a acumulaçōes orgânicas e galerias biológicas cheias com deposiçōes pardo (10YR5/3) além de pequenas áreas pardo muito pálido (10YR8/3) distintas, $10 \%$; argila; composta granular pequena e blocos. moderado a forte; duro a muito duro, friável, muito plástico, muito pegajoso; raizes grossas pouco, médias e finas abundantes; galerias biológicas pequenas e médias abundantes; macroporos abundantes; carvões pequenos comuns; limite suave, claro.

$\mathrm{A}_{12} \quad 12-44 \mathrm{~cm}$; matriz pardo muito pálido (10YR8/3; $7 / 4$ úmido e amassado) com pequenas áreas pardo amarelado (10YR5/4) $5 \%$, pouco nítidas; argila; maciço que se rompe em fragmentos angulares pequenos; muito duro, friável, muito plástico, muito pegajoso; raizes grossas pouco, médias e firas comuns; galerias blológicas pouco; macroporos comuns; carvǒes pequenos pouco: limite suave, gradual.

$\mathrm{A}_{3} / \mathrm{B}_{1} \quad 44-60 \mathrm{~cm}$; róseo (10YR7/7; $7 / 6$ úmido); argila; maciço; duro, muito friável, plástico, pegajoso: cerosidade pouco nas paredes de galerias biológicas; raizes médias pouco, finas comuns; galerias biológicas abundantes no terço superior; macroporos comuns; limite suave, gradual.

$\mathrm{B}_{21} \quad 50-115 \mathrm{~cm}$; pardo muito pálido (10YR8/4; 7,5Y7/6 úmido); argila; maciço que se rompe em blocos pequenos e granular pequena, moderado; duro, muito friável, plástico, muito pegajoso; raizes muito finas pouco: galerias biológicas pequenas, pou$\mathrm{co}$; macroporos pouco; grande número de pequeninos planos de clivagem mas amostras secas; limite suave, difuso.

$\mathrm{B}_{2} \quad 115-165 \mathrm{~cm}$; pardo muito pálido (10YR8/4; 7,5/4 úmido): argila, maciço que se rompe em blocos médios, moderado; cerosidade comum; galerias biológicas pequenas pouco: raizes muito finas pouco; macroporos pouco; grande número de pequenos planos de clivagem irregulares; limite suave, difuso.

$\mathrm{B}_{3} / \mathrm{C} 165-250 \mathrm{~cm}$; pardo muito pálido (10YR8/4; 7,5/4 úmido); argila; maciço; ligeiramente duro. muito friável, plástico, muito pegajoso.

OBS.: Abaixo de $250 \mathrm{~cm}$ camada concrecionária não penetrável com o trado.

\section{Resultados analíticos do Perfil EEST-3}

Estes resultados sāo apresentados no Quadro 4.

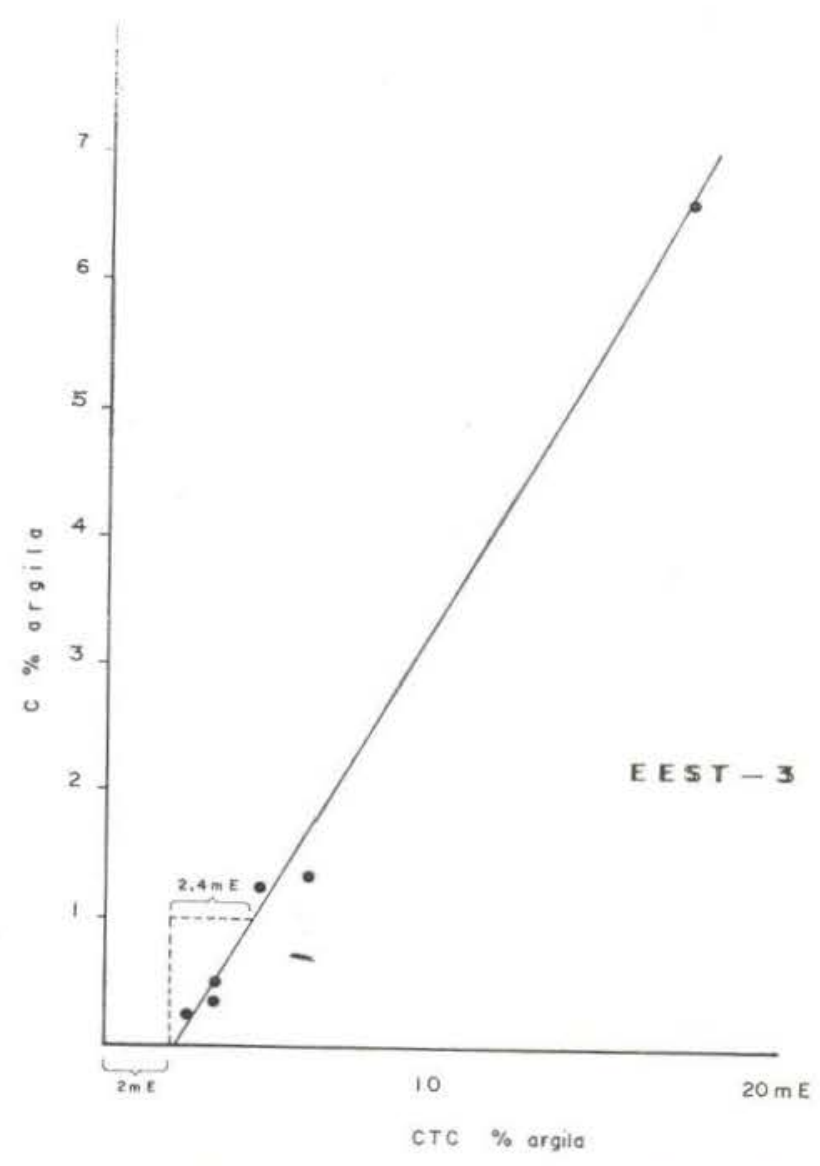

Fig. 10 - Relação C e CTC para $100 \mathrm{~g}$ de argila (segundo Bennema, 1966) do perfil EEST - 3.

PERFIL EEST - 4

\section{Morfologia do Perfil EEST-4}

DATA 21.07 .1977

CLASSIFICAÇĀO: TYPIC PALEUDULT PODZOLICO VERMELHO AMARELO, álico, Latossólico, A moderalo, textura argilosa.

LOCALIZAÇÃO: Campo Experimental n. 4 - Agricultura Ecológica a aproximadamente $3 \mathrm{~km}$ a S da sede, lado esquerdo da BR-174 meia encosta de pequena elevaçăo.

GEOLOGIA: Formação Alter-do-Chão.

MATERIAL DE ORIGEM: Arenitos e argilitos.

RELEVO LOCAL: Ondulado curto com declividade de até $15 \%$,

RELEVO REGIONAL: Suave ondulado a ondulado.

VEGETAÇĀO: Desmatamento com queima, efetuado em agosto de 1977.

DRENAGEM: Moderada a boa.

EROSÃO: Laminar ligeira.

USO ATUAL: Campo experimental com graviola, côco, caju, biribá, pupunha e guaraná. 
QUADRO 4

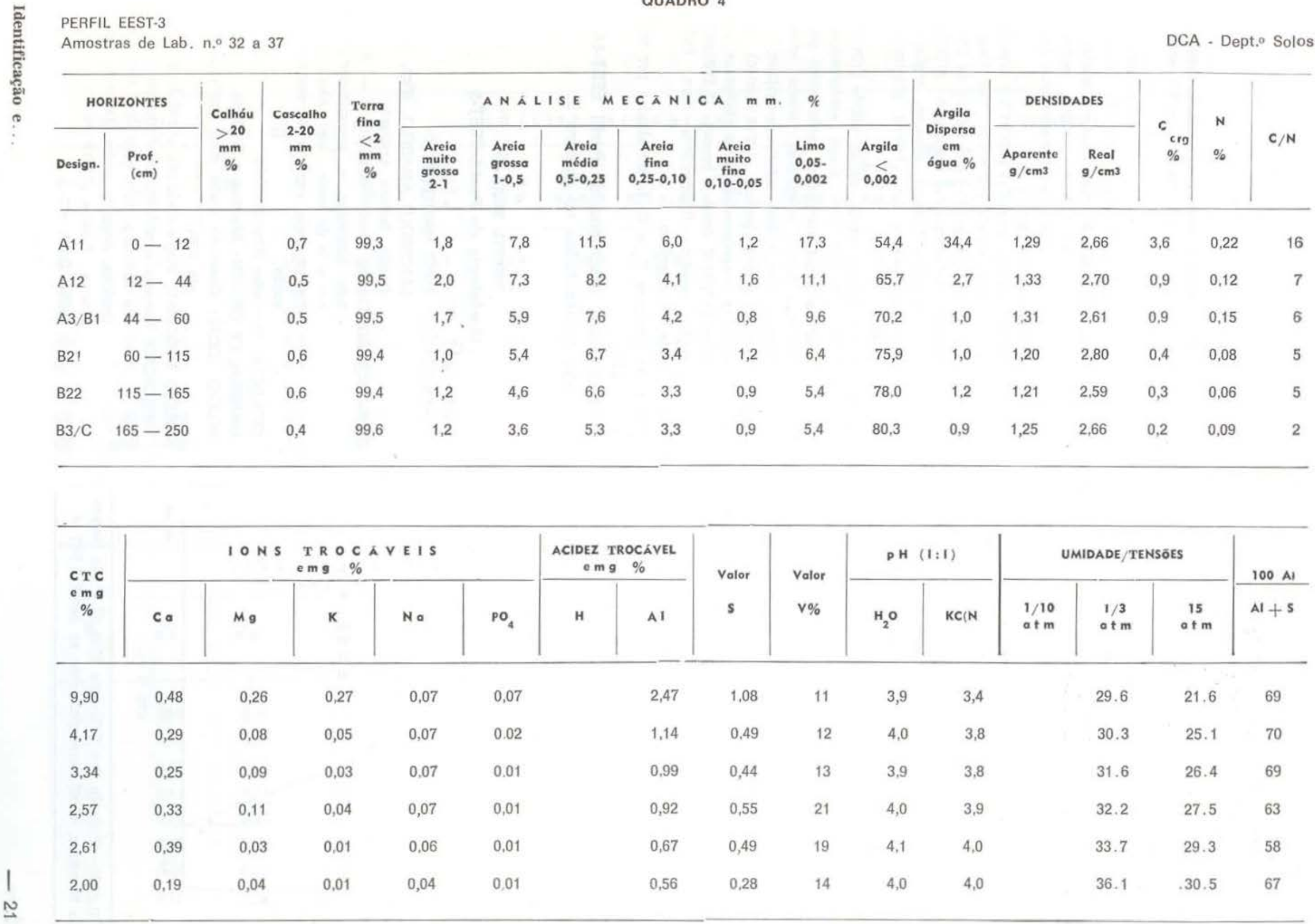


MORFOLOGIA:

A $\quad 0-15 \mathrm{~cm}$; matriz pardo amarelado claro (10YR6/3; 6/4 úmido) com marchetamento devido a acumulaçōes orgânicas pardo amarelado (10YR5/4) pouco nítido, comum; barro argilo arenoso; maciço que se rompe em fragmentos angulares e granular pequena a média. fraco a moderado: duro, friável, plástico, pegajoso: raízes grossas e médias comuns; galerias biológicas pequenas a médias comuns; limite suave, difuso.

$A_{3} 15-40 \mathrm{~cm}$; pardo muito pálido (10YR7/4; 6/4 úmido); argila arenosa: maciço que se rompe em fragmentos irregulares e granular pequena, fraco; muito duro, friável, plástico, pegajoso; raízes grossas muito pouco, médias e finas pouco; galerias biológicas muito pequenas pouco; macroporos pouco; limite suave. gradual.

$\mathrm{B}_{21} 40-68 \mathrm{~cm}$; pardo muito claro (10YR $7 / 4 ; 7,5 \mathrm{YR} 7 / 6$ úmido); argila; maciço que se rompe em blocos sub-angulares, fraco; muito duro, friável, plástico, pegajoso; cerosidade (?) ou superfícies de pressão comuns; raízes muito finas, pouco; galerias biológicas muito pequenas comuns; macroporos comuns; limite suave, difuso.

$\mathrm{B}_{22} 68-120 \mathrm{~cm} ;$ pardo muito pálido (10YR8/4; $7 / 4$ úmido); argila; maciço que se rompe em

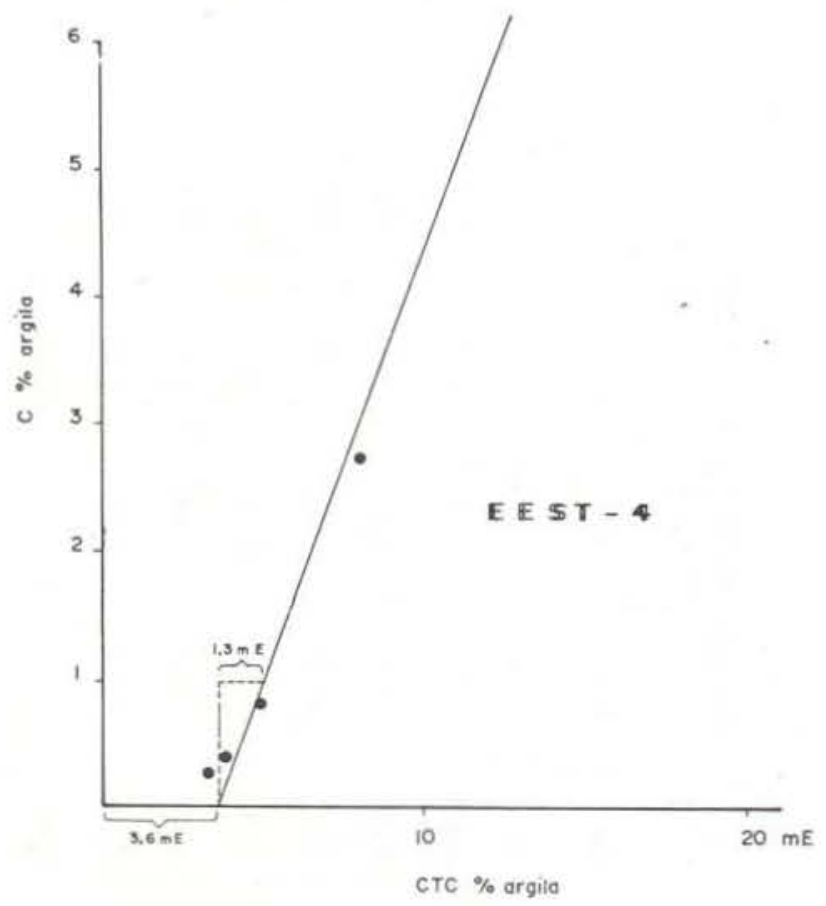

Fig. 11 - Relação C e CTC para $100 \mathrm{~g}$ de argila (segundo Bennema, 1966) correspondente ao perfil EEST - 4 . fragmentos irregulares; cerosidade (?) ou superfícies de pressão comuns; raizes finas e muito finas pouco; galerias biológicas muito pequenas pouco; macroporos pouco; limite suave, difuso.

$\mathrm{B}_{3} 120-160 \mathrm{~cm}$; matriz amarela (10YR8/6 úmido) e pardo muito pálido (10YR8/3 úmido), ocorrendo a partir de $150 \mathrm{~cm}$ esparsos fragmentos de rocha (saprólito) com 0,5 a $1 \mathrm{~cm}$ de diâmetro, irregulares, internamente vermelho (10YR5/6) com pontuações brancas, comuns; argila; maciço; muito duro, friável, plástico, pegajoso; raizes muito finas pouco: macroporos pouco; limite suave, difuso.

$C_{1} 160-200 \mathrm{~cm}$; matriz amarelo (10YR7,5/6 úmido) e pardo muito pálido (10YR8/3) com fragmentos de rocha (saprólito) em menos de $5 \%$ do volume, internamente vermelho (10YR5/6) com pontuções brancas, comuns; argila; maciço: ligeiramente duro, friável, plástico, pegajoso.

$\mathrm{C}_{2} 200-300 \mathrm{~cm}$; matriz pardo muito pálido (10YR8/3; 2,5Y8/4 úmicio) com áreas esbranquiçadas, pouco e áręs alongadas, pardo muito pálido (10YR8/4 úmido) irregulares, pouco nítidas; maciço: duro, friável, plástico, pegajoso.

$\mathrm{C}_{3} 300-400 \mathrm{~cm}$; matriz branco (2,5Y8/úmido) com manchas irregulares as vezes alongadas, amarelas (10YR7/6 úmido) branco $(2,5 \mathrm{Y} 8 / \mathrm{seco})$; argila; maciço; ligeiramente duro, friável, plástico, pegajoso.

OBS.: As amostras $C_{.}$e $C_{3}$ foram obtidas por tradagem.

Resultados analíticos do Perfil EEST-4A

São apresentados no Quadro 5.

PERFIL EEST - 5

\section{Morfologia do Perfil EEST-5}

DATA: 25.07 .1977

CLASSIFICAÇÃO: TYPIC HAPLORTHOX

LATOSSOLO AMARELO, álico, A moderado, textura argilosa.

LOCALIZAÇĀO: Campo Experimental n.० 4 - Agricultura Ecológica, a aproximadamente 3 $\mathrm{Km}$ a $\mathrm{S}$ da sede, lado esquerdo da BR-174, meia encosta de pequena elevação.

GEOLOGIA: Formação Alter-do-Chăo.

MATERIAL DE ORIGEM: Arenitos e argilitos.

RELEVO LOCAL: Ondulado curto com declividade de até $10 \%$.

RELEVO REGIONAL: Suave ondulado a ondulado.

VEGETAÇÃO: Floresta amazônica prediminando o Louro e a Abiurana, com Visgueira, Matá-matá, Cupiúba, Angelim pedra, Leiteiro, Muirapiranga, Ripeira, Maçaranduba. Paracanaúba, Breu, etc. 
QUADRO 5

\begin{tabular}{|c|c|c|c|c|c|c|c|c|c|c|c|c|c|c|c|c|c|}
\hline \multicolumn{15}{|c|}{$\begin{array}{l}\text { PERFIL EEST-4 } \\
\text { Amostras de Lab. n.० } 1 \text { a } 8\end{array}$} & \multicolumn{3}{|c|}{ DCA - Depto, Solos } \\
\hline \multicolumn{2}{|c|}{ HORIZONTES } & \multirow{2}{*}{$\begin{array}{c}\text { Calháu } \\
>20 \\
\text { mm } \\
\%\end{array}$} & \multirow{2}{*}{$\begin{array}{c}\text { Cascalho } \\
2-20 \\
\mathrm{~mm} \\
\%\end{array}$} & \multirow{2}{*}{$\begin{array}{c}\text { Terra } \\
\text { fina } \\
<2 \\
\mathbf{m m} \\
\%\end{array}$} & \multicolumn{3}{|c|}{ ANALLISE } & \multicolumn{2}{|c|}{$M E C A N I C A$} & \multicolumn{2}{|l|}{$\%$} & \multirow{2}{*}{$\begin{array}{c}\text { Argila } \\
\text { Dispersa } \\
\text { em } \\
\text { água } \%\end{array}$} & \multicolumn{2}{|c|}{ DENSIDADES } & \multirow{2}{*}{$\begin{array}{c}c_{\text {org }} \\
\%\end{array}$} & \multirow{2}{*}{$\begin{array}{l}\mathrm{N} \\
\%\end{array}$} & \multirow[b]{2}{*}{$\mathrm{C} / \mathrm{N}$} \\
\hline Design. & $\begin{array}{l}\text { Prof. } \\
\text { (cm) }\end{array}$ & & & & $\begin{array}{l}\text { Areio } \\
\text { muito } \\
\text { grossa } \\
2-1\end{array}$ & $\begin{array}{l}\text { Areia } \\
\text { grosso } \\
1-0,5\end{array}$ & $\begin{array}{c}\text { Areia } \\
\text { media } \\
0,5-0,25\end{array}$ & $\begin{array}{c}\text { Areia } \\
\text { fina } \\
0,25-0,10\end{array}$ & $\begin{array}{c}\text { Areia } \\
\text { muito } \\
\text { fina } \\
0,10-0,05\end{array}$ & $\begin{array}{l}\text { Limo } \\
0,05 \\
0,002\end{array}$ & $\underset{0,002}{\text { Argila }}$ & & $\begin{array}{l}\text { Aporente } \\
\mathrm{g} / \mathrm{cm}^{3}\end{array}$ & $\begin{array}{l}\text { Reo' } \\
\mathbf{g} / \mathrm{em}^{3}\end{array}$ & & & \\
\hline A1 & $0-15$ & & 0,8 & 99,2 & 4,1 & 19,6 & 26,5 & 11,6 & 1,4 & 9,4 & 27,4 & 17,0 & 1,54 & 2,49 & 2,9 & 0.10 & 29 \\
\hline $\mathrm{A} 3$ & $15-40$ & & 0,3 & 99,7 & 3,2 & 11,2 & 17,7 & 9,7 & 1,9 & 8,2 & 48,1 & 19,5 & 1,30 & 2,48 & 1,3 & 0,12 & 10 \\
\hline B21 & $40-68$ & & 0,3 & 99,7 & 1,1 & 7,6 & 12,9 & 7,6 & 1,4 & 9,8 & 59,6 & 0,4 & 1,37 & - & 0,5 & 0,06 & 8 \\
\hline B22 & $68-120$ & & 0,3 & 99,7 & 2,0 & 5,7 & 7,5 & 4,3 & 1,1 & 10,7 & 68,7 & 0,2 & 1,30 & 2,57 & 0,3 & 0,06 & 5 \\
\hline B3 & $120-160$ & & 1,1 & 98,9 & 1,4 & 5,2 & 7,2 & 4,1 & 1,1 & 9,6 & 71,4 & 0,7 & 1,24 & 2,44 & 0,2 & 0,05 & 4 \\
\hline $\mathrm{C} 1$ & $160-200$ & & 0,7 & 99,3 & 2,3 & 9,3 & 12,5 & 4,8 & 0,8 & 12,7 & 57,6 & 1,8 & 1,21 & 2,64 & 0,1 & 0,05 & 2 \\
\hline $\mathrm{C} 2$ & $200-300$ & & 0,5 & 99,5 & 3,6 & 11,3 & 11,8 & 6,8 & 0,6 & 10.3 & 55,6 & 1,6 & 1,20 & - & - & 0,06 & \\
\hline $\mathrm{C} 3$ & $300-400$ & & 0,9 & 99,1 & 3,8 & 12,1 & 17,1 & 10,9 & 1,1 & 8,8 & 46,2 & 1,3 & 1,20 & 2,47 & 0,1 & 0,06 & 1 \\
\hline
\end{tabular}

\begin{tabular}{|c|c|c|c|c|c|c|c|c|c|c|c|c|c|c|c|}
\hline \multirow{2}{*}{$\begin{array}{c}\text { C T C } \\
\text { e m g } \\
\%\end{array}$} & \multicolumn{5}{|c|}{$\begin{array}{c}\text { IONS TROCA TEIS } \\
\text { emg \% } \\
\end{array}$} & \multicolumn{2}{|c|}{$\begin{array}{l}\text { ACIDEZ TROCÁVEL. } \\
\text { e m g \% }\end{array}$} & \multirow{2}{*}{$\begin{array}{c}\text { Volor } \\
\text { S }\end{array}$} & \multirow{2}{*}{$\begin{array}{l}\text { Valor } \\
\text { v\% }\end{array}$} & \multicolumn{2}{|c|}{ pH $(1: 1)$} & \multicolumn{3}{|c|}{ UMIDADE/TENSŌES } & \multirow{2}{*}{$\begin{array}{l}100 \mathrm{Al} \\
\mathrm{Al}+\mathrm{S}\end{array}$} \\
\hline & $\mathrm{Ca}$ & $\mathrm{Mg}$ & K & $\mathrm{Na}$ & $\mathrm{FO}_{4}$ & H & Al & & & $\mathrm{H}_{2} \mathrm{O}$ & $K C(\mathbb{N}$ & $\begin{array}{l}1 / 10 \\
\text { at } m\end{array}$ & $\begin{array}{l}1 / 3 \\
\text { at } m\end{array}$ & $\stackrel{15}{15}$ & \\
\hline 5,30 & 0,39 & 0,16 & 0,14 & 0,19 & 0,05 & & 0,22 & 0.88 & 17 & 4,1 & 3,7 & & 18.5 & 12.1 & 20 \\
\hline 3,83 & 0,23 & 0,07 & 0,08 & 0,05 & 0,02 & & 0,71 & 0.43 & 11 & 4,1 & 3,9 & & 25.5 & 17.8 & 62 \\
\hline 2,86 & 0,28 & 0,08 & 0,09 & 0,07 & 0,01 & & 0,31 & 0.52 & 18 & 3,9 & 3,9 & & 32.2 & 22.4 & 37 \\
\hline 2,66 & 0,44 & 0,14 & 0,07 & 0,03 & 0,01 & & 0,34 & 0,68 & 25 & 4,3 & 4,1 & & 37.5 & 28.3 & 33 \\
\hline 2,41 & 0,25 & 0,05 & 0,02 & 0,03 & 0,01 & & 0,21 & 0.35 & 14 & 4,7 & 4,3 & & 38.2 & 37.8 & 37 \\
\hline 1,60 & 0,22 & 0,03 & 0,04 & 0,07 & 0,01 & & - & 0,36 & 22 & 4,8 & 4,3 & & 30.3 & 21.7 & - \\
\hline 1,24 & 0,19 & 0,03 & 0,03 & 0,07 & 0,02 & & - & 0,32 & 27 & 4,8 & 4,3 & & 27.8 & 19.9 & - \\
\hline 1,54 & 0,15 & 0,03 & 0,03 & 0,05 & 0,02 & & - & 0.26 & 17 & 4,5 & 4,1 & & 23.3 & 16.4 & - \\
\hline
\end{tabular}




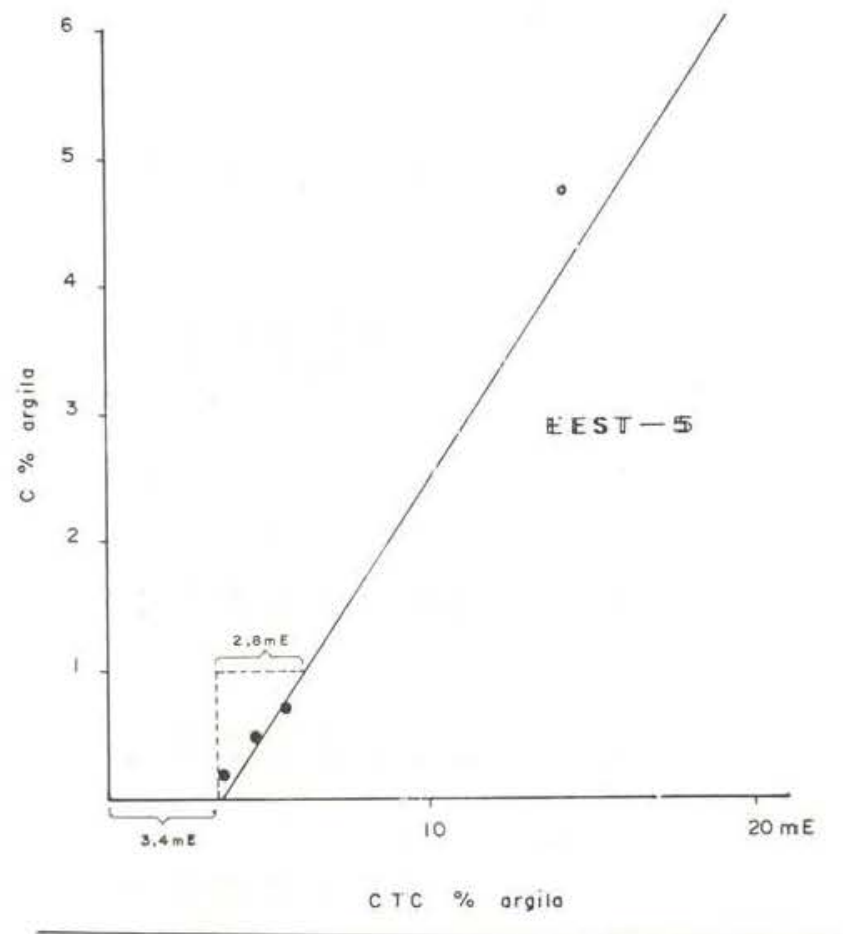

Fig. 12 - Relação C e CTC para $100 \mathrm{~g}$ de argila (segundo Bennema, 1966) correspondente ao perfil EEST - 5.

DRENAGEM: Boa a moderada.

EROSÃO: Laminar ligeira.

MORFOLOGIA:

A $\quad 0-17 \mathrm{~cm}$; matriz pardo amarelado claro (10YR7/2; $6 / 4$ úmido) com áreas irregulares (10YR7/3) e de material orgânico N2/ pequenas, pouco nítidas, comuns; barro argilo arenoso; composta blocos irregulares médios e granular pequena, fraco; duro, muito friável, plástico, pegajoso; galerias biológicas $(1-1,5 \mathrm{~cm})$ pouco; macroporos comuns; raizes grossas pouco, médias e finas comuns; esparso esqueleto de quartzo e de canga; limite suave. difuso.

$\mathrm{A}_{3} \quad 17-48 \mathrm{~cm}$; matriz amarelo pálido $(2,5 \mathrm{Y} 8 / 4 ; 2,5 \mathrm{Y} 7 / 3$ úmido) com pequenas áreas irregu'ares pardo amarelado (10YR5/4 úmido) pouco distintas, pouco; argila arenosa; maciço que se rompe em fragmentos irregulares pequenos a médios e granular pequena, fraco; duro, muito friável, plástico, pegajoso; galerias biológicas pouco; porosidade irregular, comum; raizes médias e finas comuns; limite suave, gradual.

$\mathrm{B}_{21} \quad 48-62 \mathrm{~cm}$; matriz pardo muito pálido (10YR8/4; $7 / 4$ úmido), com pontuaçôes mais escuras, pouco; argila; duro, friável, muito plástico, muito pegajoso; fragmentos de quartzo pequenos, angulosos e de canga laterítica comuns; cerosidade (?) ou superfícies de pres- são comuns; maciço que se rompe em blo$\cos$ pequenos e granular pequena, fraco; raizes muito finas comuns; galerias biológicas pouco; limite suave, gradual.

$B_{22} \quad 62-95 \mathrm{~cm}$; amarelo avermelhado (7,5YR8/4; $8 / 6$ úmido); argila; maciço que se rompe em fragmentos irregulares pequenos a médios, fraco; duro, friável, muito plástico, muito pegajoso; galerias biológicas com paredes cerozas pouco; porosidade muito pouco; raízes muito finas pouco; limite suave, difuso.

$\mathrm{B}_{3} \quad 95-126 \mathrm{~cm}$; matriz róseo $(7,5 Y R 8 / 4 ; 8 / 4$ úmido $)$ com pequenas áreas vermelho $(2,5 \mathrm{VR} 5 / 8$ úmido) esparsas e branco $(2,5 Y 8 / 2)$ pouco; argila, duro, friável, muito plástico, muito pegajoso; raízes finas pouco; cerosidade (?) ou superfícies de pressão comuns; galerıas biológicas pequenas pouco; limite suave, difuso.

$\mathrm{C}_{1} \quad 126-200 \mathrm{~cm}$; matriz róseo (7,5YR8/2; $8 / 4$ úmido) com áreas interligadas branco $(7,5 Y \mathrm{Y} 8 /) \mathrm{co}$ muns; argila; maciço; duro, friável, muito pegajoso.

$C_{2} 200-300 \mathrm{~cm}$; branco rosado $(7,6 \mathrm{YR} 8 / 2$ seco); barro argilo arenoso, maciço; duro, friável, II geiramente plástico, pegajoso.

$\mathrm{C}_{3} 300-400 \mathrm{~cm}$; branco (N8/); barro argilo arenoso. maciço; macio, muito friável, năo plástico, não pegajoso.

OES.: As amostras a partir de $200 \mathrm{~cm}$ foram obtidas por tradagem.

\section{Resultados analíticos do Perfil EEST-5} São apresentados no Quadro 6.

DATA: 02.08.1977

$$
\text { PERFIL EEST - } 6
$$

\section{Morfologia do Perfil EEST-6}

CLASSIFICAÇÃO: ORTHOXIC PALEHUMULT PODZÓLICO VERMELHO AMARELO, álico, Latossólico, A moderado, textura média.

LOCALIZAÇÃO: Mata a $170 \mathrm{~m}$ esquerda da BR-174 a $4,1 \mathrm{Km}$ da divisa $\mathrm{S}$ das terras da Estação Experimental de Silvicuitura Tropical. $A_{3}$ Espécies florestais; plantio em campinarana. Desmatamento a ser efetuado.

GEOLOGIA: Capeamentos arenosos da Formação Alter-do-Chão.

MATERIAL DE ORIGEM: Sedimentos arenosos e argilosos.

RELEVO LOCAL:

RELEVO REGIONAL:

VEGETAÇÃO ORIGINAL: Mata arenicola predomınando Envira, Papaterra, Lacre.

DRENAGEM: Boa 
QUADRO 6

\begin{tabular}{|c|c|c|c|c|c|c|c|c|c|c|c|c|c|c|c|c|c|}
\hline \multicolumn{15}{|c|}{$\begin{array}{l}\text { PERFIL EEST-5 } \\
\text { Amostras de Lab. n. } 9 \text { a } 16\end{array}$} & \multicolumn{3}{|c|}{ DCA - Depto. Solos } \\
\hline \multicolumn{2}{|c|}{ HORIZONTES } & \multirow{2}{*}{$\begin{array}{c}\text { Colháu } \\
>20 \\
\text { mm } \\
\%\end{array}$} & \multirow{2}{*}{$\begin{array}{c}\text { Cascalho } \\
2-20 \\
\text { mm } \\
\%\end{array}$} & \multirow{2}{*}{$\begin{array}{c}\text { Terra } \\
\text { fina } \\
<2 \\
<^{2} \\
\%\end{array}$} & \multicolumn{3}{|c|}{ ANALLISE } & \multicolumn{2}{|c|}{$M E C A N I C A$} & \multicolumn{2}{|l|}{$\%$} & \multirow{2}{*}{$\begin{array}{c}\text { Argila } \\
\text { Disperso } \\
\mathrm{em} \\
\text { ogua \% }\end{array}$} & \multicolumn{2}{|c|}{ DENSIDADES } & \multirow{2}{*}{$\begin{array}{l}\mathbf{c}_{\text {org }} \\
\%\end{array}$} & \multirow{2}{*}{$\begin{array}{l}\mathrm{N} \\
\%\end{array}$} & \multirow{2}{*}{$C / N$} \\
\hline Design. & $\begin{array}{l}\text { Prof, } \\
\text { (cm) }\end{array}$ & & & & $\begin{array}{l}\text { Areio } \\
\text { muito } \\
\text { grosso } \\
2-1\end{array}$ & $\begin{array}{l}\text { Areia } \\
\text { grossa } \\
1-0,5\end{array}$ & $\begin{array}{l}\text { Areia } \\
\text { media } \\
0,5-0,25\end{array}$ & $\begin{array}{c}\text { Areia } \\
\text { fina } \\
0,25-0,10\end{array}$ & $\begin{array}{c}\text { Areia } \\
\text { muito } \\
\text { fina } \\
0,10-0,05\end{array}$ & $\begin{array}{l}\text { Limo } \\
0,05 . \\
0,002\end{array}$ & $\begin{array}{c}\text { Argila } \\
\underset{0,002}{<}\end{array}$ & & $\begin{array}{l}\text { Aparente } \\
\mathrm{g} / \mathrm{cm}^{3}\end{array}$ & $\begin{array}{l}\text { Real } \\
\mathrm{g} / \mathrm{cm}^{3}\end{array}$ & & & \\
\hline A1 & $0-17$ & & 1,8 & 98,2 & 3,1 & 17,9 & 31,0 & 12,2 & 1,3 & 8,2 & 26,3 & 19,6 & 1,50 & 2,55 & 3,0 & 0,15 & 20 \\
\hline A3 & $17-48$ & & 0,9 & 99,1 & 4,5 & 13,6 & 18,2 & 8,9 & 1,7 & 6,8 & 47,3 & 2,3 & 1,30 & 2,53 & 1,0 & 0,07 & 14 \\
\hline B21 & $48-62$ & & 8,0 & 92,0 & 2,8 . & 9,4 & 14,9 & 7,6 & 1,2 & 1,4 & 62,7 & 0,7 & 1,38 & 2,50 & 0,6 & 0,05 & 12 \\
\hline B22 & $62-95$ & & 1,5 & 98,5 & 3,5 & 8,4 & 10,6 & 5,4 & 1,0 & 9,0 & 62,1 & 0,4 & 1,30 & 2,40 & 0,3 & 0,07 & 4 \\
\hline B3 & $95-126$ & & 0,4 & 99,6 & $3 ; 5$ & 11,6 & 9,2 & 3,3 & 0,6 & 12,7 & 59,1 & 0,8 & 1,24 & 2,42 & 0,1 & 0,07 & 1 \\
\hline $\mathrm{C} 1$ & $126-200$ & & 0,4 & 99,6 & 2,5 & 10,8 & 11,2 & 3,7 & 0,7 & 10,0 & 61,1 & 7,6 & 1,21 & 2,43 & 0,1 & 0,07 & 1 \\
\hline $\mathrm{C} 2$ & $200-300$ & & - & - & 6,8 & 20,7 & 21,6 & 8,2 & 1.2 & 8.5 & 33,0 & 0,5 & 1,21 & 2,51 & - & 0,02 & 1 \\
\hline C3 & $300-400$ & & 1,5 & 98,5 & 8,7 & 34,5 & 24,1 & 5,5 & 05 & 6,1 & 20,6 & 0,3 & 1,20 & 2,41 & - & 0,03 & 33 \\
\hline
\end{tabular}

\begin{tabular}{|c|c|c|c|c|c|c|c|c|c|c|c|c|c|c|c|}
\hline \multirow{2}{*}{$\begin{array}{l}\text { c Tc } \\
\text { e mg } \\
\%\end{array}$} & \multicolumn{5}{|c|}{$\begin{array}{c}\text { IONS TOCAVEIS } \\
\text { emg } \% \\
\end{array}$} & \multicolumn{2}{|c|}{$\begin{array}{c}\text { ACIDEZ TROCÁVEL } \\
\text { e m g \% }\end{array}$} & \multirow{2}{*}{$\begin{array}{c}\text { Volor } \\
\text { S }\end{array}$} & \multirow{2}{*}{$\begin{array}{l}\text { Valor } \\
\text { v\% }\end{array}$} & \multicolumn{2}{|c|}{ PH $(1: 1)$} & \multicolumn{3}{|c|}{ UMIDADE/TENSÖES } & \multirow{2}{*}{$\begin{array}{l}100 \mathrm{Al} \\
\mathrm{AI}+\mathrm{S}\end{array}$} \\
\hline & $\mathrm{Co}$ & $\mathrm{Mg}$ & K & $\mathrm{Na}$ & $\mathrm{FO}_{4}$ & H & Al & & & $\mathrm{H}_{2} \mathrm{O}$ & $\mathrm{KC}(\mathrm{N}$ & $\begin{array}{l}1 / 10 . \\
\text { at } m\end{array}$ & $\begin{array}{l}1 / 3 \\
0+m\end{array}$ & $\begin{array}{c}15 \\
0+m\end{array}$ & \\
\hline 4,95 & 0,24 & 0,21 & 0,15 & 0,07 & 0,03 & & 0.78 & 0,67 & 13 & 4,2 & 3,7 & & 15.6 & 10.5 & 54 \\
\hline 3,96 & 0,18 & 0,08 & 0,13 & 0,09 & 0,01 & & 0,60 & 0,48 & 12 & 4.1 & 3,9 & & 25.1 & 18.2 & 55 \\
\hline 2,37 & 0,14 & 0,05 & 0,04 & 0,06 & 0,01 & & 0,15 & 0.29 & 12 & 4,1 & 3,9 & & 27.2 & 21.4 & 34 \\
\hline 2,09 & 0,19 & 0,05 & 0,03 & 0,06 & 0,01 & & 0.65 & 0,33 & 16 & 4,2 & 4,0 & & 29.1 & 23.4 & 66 \\
\hline 1,93 & 0.16 & 0,03 & 0,03 & 0,07 & 0,01 & & 0,56 & 0,29 & 15 & 4,1 & 4,0 & & 25.6 & 23.1 & 66 \\
\hline 1,44 & 0,13 & 0,04 & 0,02 & 0,07 & 0,01 & & 0,59 & 0,26 & 18 & 4,3 & 4,3 & & 25.6 & 23.0 & 69 \\
\hline 0,83 & 0.13 & 0,03 & 0,02 & 0,05 & 0,01 & & 0,44 & 0.23 & 28 & 4,3 & 4,0 & & 17.9 & 12.6 & 66 \\
\hline 0,50 & 0.18 & 0,03 & 0,03 & 0,06 & 0,01 & & 0,26 & 0,30 & 60 & 4,3 & 4,0 & & 13.6 & 7.8 & 46 \\
\hline
\end{tabular}




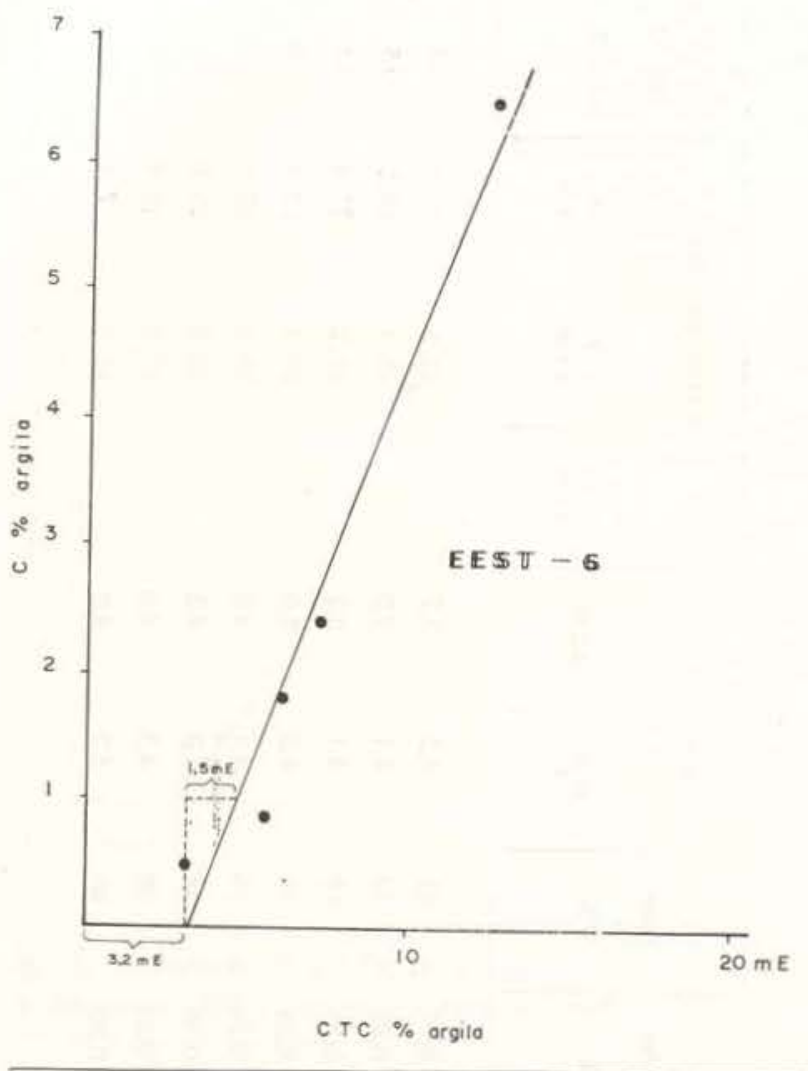

Fig. 13 - Relação C e CTC para $100 \mathrm{~g}$ de argila (segundo Bennema, 1966) correspondente ao perfil EEST - 6.

EROSĀO: Ausente.

USO ATUAL: Área a ser desmatada com queima para experimentação.

MORFOLOGIA:

O 2-0 $0 \mathrm{~cm}$; sarrapilheira constituída de deposições vegetais sobre emaranhado de raizes finas e médias semelhante a turfa.

$\mathrm{A}_{11} \quad 0-12 \mathrm{~cm}$; matriz pardo amarelado claro (10YR6/4; $4 / 4$ úmido) com $10 \%$ dé acumulaçōes orgânicas (N2/) pequenas, distinto e galerias de termitas pardo acinzentado escuro (10YR4/2; $3 / 2$ úmido) médias, $30 \%$, distinto; pardo (10YR4/3 amassado); areia barrenta; grăos simples; macio, muito friável, não plástico, não pegajoso; raizes grossas pouco, médias comuns e finas abundantes; macroporos comuns; carvōes pequenos comuns; limite suave, claro.

$\mathrm{A}_{12} \quad 12-31 \mathrm{~cm} ;$ matriz pardo acinzentado (10YR5/2; $3 / 2$ úmido) com $10 \%$ de galerias (termitas) pardo acinzentado escuro (10YR4/2: $3 / 2$ úmido) distinto, $5 \%$ de acumulaçōes orgânicas pequenas (N2/) e $5 \%$ de áreas irregulares pardo muito pálido (10YR7/4), distinto, pardo (10YR5/3 amassado); barro arenoso; maciço; ligeiramente duro muito friável, ligeiramente plástico, ligeiramente pegajoso: raízes grossas e médias pouco, finas comuns; galerias biológicas (termitas) comuns; carvōes pequenos pouco; limite suave, difuso.

$\mathrm{A}_{13} \quad 31-66 \mathrm{~cm}$; pardo amarelado claro (10YR6/4; 4/4 úmido); barro argilo arenoso; maciço que se rompe em granular média fraco; ligeiramente duro, muito friável, ligeriamente plástico, ligeiramente pegajoso; raizes muito finas comuns; galerias biológicas pequenas pouco; carvōes pequenos e médios comuns; limite suave, gradual.

$\mathrm{A}_{3} / \mathrm{B}_{1} \quad 66-95 \mathrm{~cm}$; matriz pardo amarelado claro (10YR6/4; 5/4 úmido), com fragmentos mais argilosos médios, $15 \%$ pardo muito pálido (10YR8/4; $7 / 6$ úmido), distinto; barro argilo arenoso; maciço; ligeiramente duro, muito friável, ligeiramente plástico, pegajoso; raizes muito finas comuns; galerias biológicas pequenas pouco; limite suave, gradual.

$\mathrm{B}_{21} \quad 95-136 \mathrm{~cm}$; amarelo avermelhado (10YR7/8; 7,5YR6/8 úmido); barro argilo arenoso; maciço; ligeiramente duro. muitc friável. ligeiramente plástico, pegajoso: raizes grossas pouco, finas comuns; galerias biológicas pequenas comuns; algumas concreçōes ferruginosas em linhas descontinuas; carvōes pequenos pouco; limite suave, difuso.

$\mathrm{B}_{22} \quad 136-220 \mathrm{~cm}$; amarelo avermelhado (7,5YR7/6; 5YR7/8 úmido); barro argilo arenoso: maciço; ligeiramente duro, muito friável, ligeiramente plástico, pegajoso; concreçōes ferruginosas muito pequenas, pouco; pequeninas pontuações negras comuns.

$\mathrm{B}_{3} / \mathrm{C} 220-315 \mathrm{~cm}$; róseo (5YR8/4; 7,5YR8/6 úmído); argila arenosa; maciço; ligeiramente duro, muito friável, ligeiramente plástico, pegajoso: pequenas pontuações negras comuns; concreções ferruginosas pequenas pouco.

OBS.: A partir de $200 \mathrm{~cm}$ as amostras foram obtidas por tradagem.

Resultados analíticos do Perfil EEST-6 São apresentados no Quadro 7.

\section{PERFIL EEST - 7 \\ Morfologia do Perfil EEST-7}

DATA: 05.08 .1977

CLASSIFICAÇĀO: TYPIC PALEUDULT

PODZOLICO VERMELHO AMARELO, álico, Latossólico, A moderadc, textura argilosa.

LOCALIZAÇÃO: Próximo a divisa $S$ da área da Estação Experimental de Silvicultura Tropical, lado esquerdo da BR-174, penetrando $\pm 1,6 \mathrm{Km}$ 


\begin{tabular}{|c|c|c|c|c|c|c|c|c|c|c|c|c|c|c|c|c|c|}
\hline \multicolumn{15}{|c|}{$\begin{array}{l}\text { PERFIL EEST-6 } \\
\text { Amostras de Lab, n, } 038 \text { a } 44\end{array}$} & \multicolumn{3}{|c|}{ DCA - Dept.o Solos } \\
\hline \multicolumn{2}{|c|}{ HORIZONTES } & \multirow{2}{*}{$\begin{array}{c}\text { Calhóu } \\
>20 \\
\mathrm{~mm} \\
\%\end{array}$} & \multirow{2}{*}{$\begin{array}{c}\text { Cascalho } \\
2-20 \\
\mathrm{~mm} \\
\%\end{array}$} & \multirow{2}{*}{$\begin{array}{c}\text { Terra } \\
\text { fina } \\
<\mathbf{2} \\
\mathbf{m m} \\
\%\end{array}$} & \multicolumn{3}{|c|}{ ANALISE } & \multicolumn{2}{|c|}{$M E C A N I C A$} & \multicolumn{2}{|l|}{$\%$} & \multirow{2}{*}{$\begin{array}{c}\text { Argila } \\
\text { Dispersa } \\
\text { em } \\
\text { agua \% }\end{array}$} & \multicolumn{2}{|c|}{ DENSIDADES } & \multirow{2}{*}{$\mathrm{c}_{\text {org }}$} & \multirow{2}{*}{$\begin{array}{l}\mathrm{N} \\
\%\end{array}$} & \multirow[b]{2}{*}{$\mathrm{C} / \mathrm{N}$} \\
\hline Design. & $\begin{array}{l}\text { Prot, } \\
\text { (cm) }\end{array}$ & & & & $\begin{array}{l}\text { Areio } \\
\text { muito } \\
\text { grosso } \\
2-1\end{array}$ & $\begin{array}{l}\text { Areia } \\
\text { grossa } \\
1-0,5\end{array}$ & $\begin{array}{l}\text { Areia } \\
\text { média } \\
0,5-0,25\end{array}$ & $\begin{array}{l}\text { Areia } \\
\text { fina } \\
0,25-0,10\end{array}$ & $\begin{array}{c}\text { Areia } \\
\text { muito } \\
\text { fino } \\
0,10-0,05\end{array}$ & $\begin{array}{l}\text { Limo } \\
0,05 \\
0,002\end{array}$ & $\begin{array}{l}\text { Argilo } \\
0,002\end{array}$ & & $\begin{array}{l}\text { Aporente } \\
9 / \mathrm{cm}^{3}\end{array}$ & $\begin{array}{c}\text { Real } \\
\mathrm{g} / \mathrm{cm}^{3}\end{array}$ & & & \\
\hline 0 & $2-0$ & & - & - & - & - & - & - & - & - & - & - & - & - & - & - & - \\
\hline A11 & $0-12$ & & 0,4 & 99,6 & 2,3 & 20,0 & 42,0 & 16,7 & 3,7 & 5,2 & 10,1 & 7,5 & 1,40 & 2,56 & 1.1 & 0.12 & 9 \\
\hline A12 & $12-31$ & & 0,2 & 99,8 & 1,6 . & 21,5 & 43,8 & 12,6 & 1,5 & 3,8 & 15,2 & 12,0 & 1,40 & 2,46 & 2.6 & 0,21 & 12 \\
\hline A13 & $31-66$ & & 0,3 & 99,7 & 1,8 & 18,0 & 36,3 & 14,8 & 2,4 & 4.7 & 22,0 & 20,1 & 1,41 & 2,54 & 1,2 & 0,08 & 15 \\
\hline $\mathrm{A} 3 / \mathrm{B} 1$ & $66-95$ & & 0,2 & 99,8 & 2,8 & 15,9 & 36.7 & 14,1 & 2,1 & 4,0 & 24,4 & 5,6 & 1,42 & 2,53 & 0,6 & 0,07 & 8 \\
\hline B21 & $95-136$ & & 0,7 & 99,3 & 3,9 & 21,0 & 35,6 & 11,4 & 1,4 & 4,1 & 22,6 & 1,2 & 1,41 & 2,57 & 0,4 & 0,08 & 5 \\
\hline B22 & $136-220$ & & 0,5 & 99,5 & 2,8 & 13,3 & 29,1 & 15,6 & 2,0 & 5,7 & 31,5 & 0,9 & 1,50 & 2,54 & 0,3 & 0,07 & 4 \\
\hline B3/C & $220-315$ & & - & - & 2,3 & 11,6 & 21,1 & 15,2 & 2,3 & 6.7 & 40,8 & 0.5 & 1,50 & 2,56 & 0,2 & 0,06 & 3 \\
\hline
\end{tabular}

\begin{tabular}{|c|c|c|c|c|c|c|c|c|c|c|c|c|c|c|c|}
\hline \multirow{2}{*}{$\begin{array}{c}\text { с T C } \\
\text { e m g } \\
\%\end{array}$} & \multicolumn{5}{|c|}{$\begin{array}{c}\text { IONS TROCAVEIS } \\
\text { emg \% }\end{array}$} & \multicolumn{2}{|c|}{$\begin{array}{l}\text { ACIDEZ TROCAVEL } \\
\text { e m g \% } \\
\end{array}$} & \multirow{2}{*}{$\begin{array}{c}\text { Volor } \\
\text { S }\end{array}$} & \multirow{2}{*}{$\begin{array}{l}\text { Volor } \\
\text { v\% }\end{array}$} & \multicolumn{2}{|c|}{ PH $(1: 1)$} & \multicolumn{3}{|c|}{ UMIDADE/TENSÖES } & \multirow{2}{*}{$\begin{array}{l}100 \mathrm{Al} \\
\mathrm{Al}+\mathrm{S}\end{array}$} \\
\hline & $\mathrm{Co}$ & $\mathrm{Mg}$ & 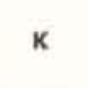 & $\mathrm{No}$ & $\mathrm{PO}_{4}$ & H & AI & & & $\mathrm{H}_{2} \mathrm{O}$ & $\mathrm{KC}(\mathrm{N}$ & $\begin{array}{l}1 / 10 \\
o+m\end{array}$ & $\begin{array}{l}1 / 3 \\
o+m\end{array}$ & $\begin{array}{c}15 \\
\text { of } m\end{array}$ & \\
\hline 4,58 & 0,13 & 0.07 & 0,06 & 0,04 & 0,03 & & 0,93 & 0,30 & 6 & 4,4 & 3,6 & & 7.4 & 6.2 & 76 \\
\hline 3,88 & 0,14 & 0,05 & 0,04 & 0,05 & 0,04 & & 0,80 & 0.28 & 7 & 4,7 & 4,1 & & 10.7 & 8.6 & 74 \\
\hline 2,70 & 0.12 & 0,03 & 0,02 & 0,05 & 0,01 & & 0,67 & 0,22 & 8 & 4,4 & 4,1 & & 12.3 & 10.9 & 75 \\
\hline 1,72 & 0,13 & 0,03 & - & 0,03 & 0,01 & & 0,39 & 0.19 & 11 & 4,4 & 4,2 & & 12.6 & 10.0 & 67 \\
\hline 1,35 & 0,14 & 0,03 & 0,01 & 0,05 & 0,01 & & 0,28 & 0,23 & 17 & 4,4 & 4,2 & & 12.4 & 10.7 & 55 \\
\hline 1,76 & 0,17 & 0,04 & - & 0.05 & 0,03 & & 0,31 & 0,26 & 15 & 4,5 & 4.2 & & 14.4 & 12.0 & 54 \\
\hline 1,26 & 0,14 & 0,03 & - & 0,05 & 0,02 & & 0,21 & 0,22 & 27 & 4,5 & 4,3 & & 20.2 & 16.8 & 49 \\
\hline
\end{tabular}


GEOLOGIA: Formação Alter-do-Chão.

MATERIAL DE ORIGEM: Sedimentos argilosos.

RELEVO LOCAL: Plano.

RELEVO REGIONAL: Plano a suave ondulado.

VEGETAÇĀO: Floresta Amazônica: Angelim, Louro, Murapiranga.

DRENAGEM: Moderada.

EROSĀO: Ausente.

USO ATUAL: Mata broqueada - A6 - Ensaio com espécies florestais.

\section{MORFOLOGIA}

$A_{11} \quad 0-18 \mathrm{~cm}$; matriz amarelo pálido $(2,5 Y 7 / 4 ; 6 / 6$ úmido) com áreas pardo oliva claro $(2,5 \mathrm{Y} 5 / 4)$ médias, irregulares, pouco nítidas, comuns; argila; blocos angulares pequenos e granular pequena, fraco a moderado; muito duro, friável, muito plástico, muito pegajoso; raízes grossas pouco, médias e finas abundantes; galerias biológicas pequenas e médias comuns; macroporos abundantes; acumulações orgânicas médias, comuns; limite suave, gradual.

$\mathrm{A}_{12} \quad 18-47 \mathrm{~cm}$; amarelo pálido $(2,5 \mathrm{Y} 8 / 4 ; 10 \mathrm{YR} 7 / 6$ úmido); argila; maciço que se rompe em blocos e micro-agregados, moderado a fraco; duro, friável, plástico, muito pegajoso; raizes grossas pouco, finas comuns; galerias biológicas pequenas e médias comuns; macroporos abundantes: limite suave, difuso.

$\mathrm{B}_{21} \quad 47-91 \mathrm{~cm}$; amarelo (10YR $/ 6 ; 6 / 8$ úmido); argila; maciço que se rompe em blocos pequenos e

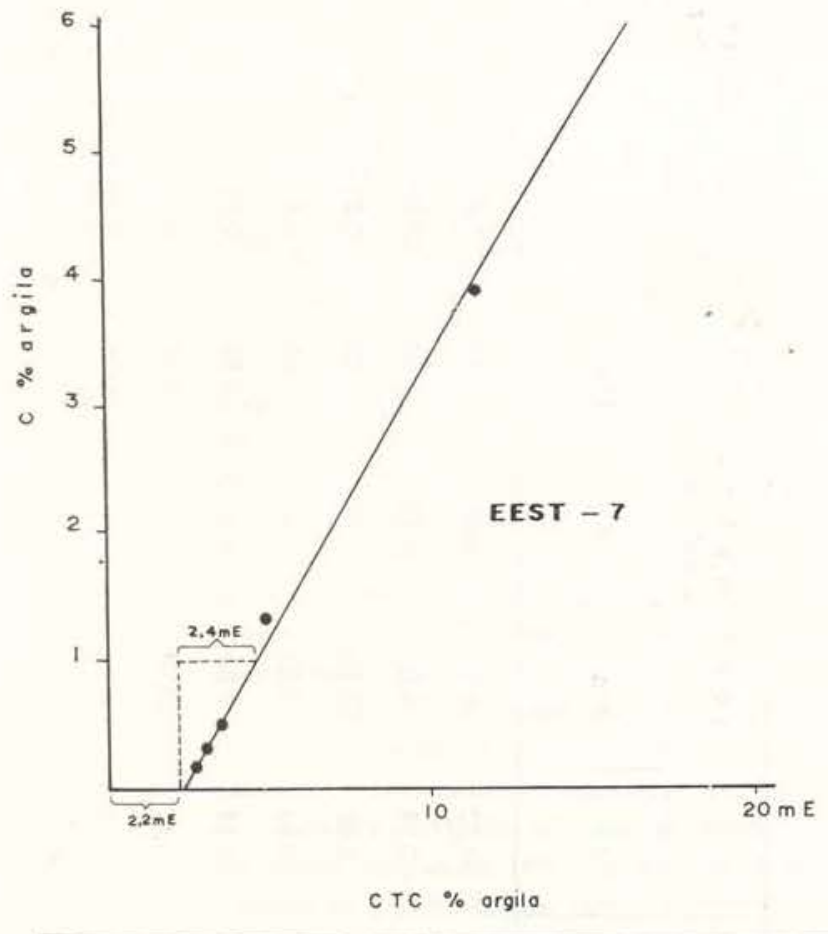

Fig. 14 - Relação C e CTC para $100 \mathrm{~g}$ de argila (segundo Bennema, 1966) correspondente ao perfil EEST-7. micro-agregados, moderado; duro, friável, plástico, muito pegajoso; cerosidade fraca nas paredes de galerias biológicas; raízes finas comuns; galerias biológicas pequenas comuns; macıoporos comuns; limite suave, difuso.

$\mathrm{B}_{22} 91-133 \mathrm{~cm}$; pardo muito pálido (10YR8/4; $7 / 8$ úmido); argila; maciço que se rompe em blocos pequenos, moderado; duro, friável, plástico, muito pegajoso; cerosidade bem evidenciada, comum; raízes muito finas comuns; galerias biológicas pequenas pouco; limite suave, difuso.

$\mathrm{B}_{23} 133-174 \mathrm{~cm}$; amarelo (10YR8/6; $7 / 8$ úmido); argila; maciço; ligeiramente duro a duro, friável, plástico, muito pegajoso; cerosidade comum; raízes finas pouco; galerias biológicas pequenas, pouco; macroporos pouco; limite suave, difuso.

$\mathrm{B}_{3} 174-273 \mathrm{~cm}$; amarelo (10YR8/6; 7,5YR úmido); argila; maciço; duro, muito friável, plástico, muito pegajoso; cerosidade abundante semeIhante a superfícies de pressăo; planos de clivagem pequenos, irregulares, abundantes; raízes muito finas pouco, no terço superior.

C $273-365+\mathrm{cm}$; branco (N8/; 10YR8/6 úmido); argila; maciço; extremamente duro, muito friável, muito plástico, muito pegajoso.

OBS.: As amostras a partir de $200 \mathrm{~cm}$ de profundidade foram obtidas com auxilio de tradagem.

Resultados analíticos do Perfil EEST-7 São apresentados no Quadro 8.

PERFIL EEST - 8

\section{Morfologia do Perfil EEST-8}

DATA: $09.08-1977$

CLASSIFICAÇÃO: TYPIC ACRORTHOX

LATOSSOLO AMARELO, álico, A moderado, textura argilosa.

LOCALIZAC̄ĂO: Na parte $S$ próximo à divisa, lado esquerdo da BR-174, penetração de $\pm 1000 \mathrm{~m}$ por antiga estrada, sobre extenso platô.

GEOLOGIA: Formaçäo Alter-do-Chão.

MATERIAL DE ORIGEM: Sedimentos argiloso.

RELEVO LOCAL: Plano.

RELEVO REGIONAL: Plano a suave ondulado.

VEGETAÇĀO: Mata argilícola: Cumaru, Matá-matá, Louro, Canjarana, Angelim, Quariquara branca (quina), Envira.

DRENAGEM: Moderada a boa.

EROSĀO: Ausente.

USO ATUAL: Área destinada a cultivos sombreados. MORFOLOGIA:

$\mathrm{A}_{11} \quad 0-14 \mathrm{~cm}$; matriz amarelo pálido $(2,5 Y 7 / 4 ; 6 / 6$ úmido) com pequenas áreas pardo oliva claro $(2,5 Y 5 / 4)$ de acumulações orgânicas 
QUADRO 8

\begin{tabular}{|c|c|c|c|c|c|c|c|c|c|c|c|c|c|c|c|c|c|}
\hline \multicolumn{15}{|c|}{$\begin{array}{l}\text { PERFIL EEST-7 } \\
\text { Amostras de Lab. n. } 45 \text { a } 51\end{array}$} & \multicolumn{3}{|c|}{ DCA - Dept. Solos } \\
\hline \multicolumn{2}{|c|}{ HORIZONTES } & \multirow{2}{*}{$\begin{array}{c}\text { Colhóu } \\
>20 \\
\mathrm{~mm} \\
\%\end{array}$} & \multirow{2}{*}{$\begin{array}{c}\text { Cascalho } \\
2-20 \\
\mathrm{~mm} \\
\%\end{array}$} & \multirow{2}{*}{$\begin{array}{l}\text { Terra } \\
\text { fina } \\
<2 \\
m m \\
\%\end{array}$} & \multicolumn{3}{|c|}{$A N A L L I S E$} & \multicolumn{2}{|c|}{$M E C A N I C A$} & \multicolumn{2}{|l|}{$\%$} & \multirow{2}{*}{$\begin{array}{c}\text { Argila } \\
\text { Dispersa } \\
\text { em } \\
\text { aguo \% }\end{array}$} & \multicolumn{2}{|c|}{ DENSIDADES } & \multirow{2}{*}{$c_{\text {cro }}$} & \multirow{2}{*}{$\begin{array}{l}\mathrm{N} \\
\%\end{array}$} & \multirow[b]{2}{*}{$\mathrm{C} / \mathrm{N}$} \\
\hline Design. & $\begin{array}{l}\text { Prot, } \\
\text { (cm) }\end{array}$ & & & & $\begin{array}{c}\text { Areio } \\
\text { muito } \\
\text { grosso } \\
2-1\end{array}$ & $\begin{array}{l}\text { Areia } \\
\text { grossa } \\
1-0,5\end{array}$ & $\begin{array}{c}\text { Areia } \\
\text { média } \\
0,5-0,25\end{array}$ & $\begin{array}{c}\text { Areia } \\
\text { fina } \\
0,25-0,10\end{array}$ & $\begin{array}{c}\text { Areio } \\
\text { muito } \\
\text { fina } \\
0,10-0,05\end{array}$ & $\begin{array}{l}\text { Limo } \\
0,05- \\
0,002\end{array}$ & $\begin{array}{l}\text { Argila } \\
0,002\end{array}$ & & $\begin{array}{l}\text { Aparente } \\
9 / \mathrm{cm}^{3}\end{array}$ & $\begin{array}{l}\text { Real } \\
9 / \mathrm{cm}^{3}\end{array}$ & & & \\
\hline A11 & $0-18$ & & & & 0,3 & 3,6 & 9,2 & 3,9 & 0,5 & 18,5 & 64,0 & 0,7 & 1,20 & 2,50 & 2,5 & 0,20 & 12 \\
\hline A12 & $18-47$ & & & & 0,2 & 1,7 & 4,8 & 2,4 & 0,4 & 9,9 & 80,6 & 0,1 & 1,20 & 2.63 & 1,1 & 0,13 & 8 \\
\hline B21 & $47-97$ & & & & 0,2 & 1,5 & 3,8 & 1,7 & 0,3 & 6,9 & 85,6 & 0,8 & 1,07 & 2,63 & 0,4 & 0,10 & 4 \\
\hline B22 & $91-133$ & & 0,4 & 99,6 & 0,3 & 1,7 & 3,4 & 1,6 & 0,3 & 8,2 & 84,5 & 0,1 & 1,12 & 2,52 & 0,3 & 0,08 & 4 \\
\hline B23 & $133-174$ & & & & 0,5 & 1,4 & 2,8 & 1,6 & 0,4 & 8,4 & 84,9 & 0,4 & 1,16 & 2,43 & 0,2 & 0,14 & 1 \\
\hline B3 & $174-273$ & & & & 0,2 & 0.7 & 2,2 & 1,6 & 0,5 & 8,9 & 85,9 & 1,1 & 1,28 & 2,50 & 0,1 & 0,08 & 1 \\
\hline C & $273-365+$ & & & & 0,2 & 1,2 & 1,6 & 1,0 & 0,4 & 11,6 & 84,0 & 0,7 & 1,28 & 2,54 & 0,2 & 0,07 & 3 \\
\hline
\end{tabular}

\begin{tabular}{|c|c|c|c|c|c|c|c|c|c|c|c|c|c|c|c|}
\hline \multirow{2}{*}{$\begin{array}{l}\text { C T C } \\
\text { e mg } \\
\%\end{array}$} & \multicolumn{5}{|c|}{$\begin{array}{c}\text { IONS TROCÁVEIS } \\
\text { emg \% }\end{array}$} & \multicolumn{2}{|c|}{$\begin{array}{l}\text { ACIDEZ TROCÁVEL } \\
\text { e m g \% }\end{array}$} & \multirow{2}{*}{$\begin{array}{c}\text { Valor } \\
\text { S }\end{array}$} & \multirow{2}{*}{$\begin{array}{l}\text { Volor } \\
\text { v\% }\end{array}$} & \multicolumn{2}{|c|}{ p $H(1: 1)$} & \multicolumn{3}{|c|}{ UMIDADE/TENSŌES } & \multirow{2}{*}{$\begin{array}{l}100 \mathrm{~A} \\
\mathrm{Al}+\mathrm{s}\end{array}$} \\
\hline & $\mathrm{co}$ & $\mathrm{Mg}$ & $\kappa$ & $\mathrm{No}$ & $\mathrm{PO}_{4}$ & H & $A I$ & & & $\mathrm{H}_{2} \mathrm{O}$ & $\mathrm{KC}(\mathrm{N}$ & $\begin{array}{l}1 / 10 \\
\text { of } m\end{array}$ & $\begin{array}{l}1 / 3 \\
0+m\end{array}$ & $\begin{array}{c}15 \\
\text { at } m\end{array}$ & \\
\hline 7,38 & 0,14 & 0,12 & 0,12 & 0,10 & 0,02 & & 1,80 & 0,48 & 6 & 4,1 & 3,7 & & 35.4 & 28.2 & 79 \\
\hline 4,42 & 0.14 & 0,08 & 0,02 & 0.10 & 0,01 & & 1,14 & 0,34 & 7 & 4.2 & 3,9 & & 30.1 & 27.8 & 77 \\
\hline 3.14 & 0,12 & 0,03 & - & 0,05 & 0,01 & & 3,83 & 0.20 & 6 & 4,4 & 4,0 & & 40.3 & 32.5 & 80 \\
\hline 3,08 & 0,12 & 0,03 & - & 0,05 & 0.01 & & 0,81 & 0,20 & 6 & 4,4 & 4,1 & & 40.8 & 35.0 & 80 \\
\hline 2,76 & 0,13 & 0,02 & - & 0,05 & 0,01 & & 0,41 & 0,20 & 7 & 4,6 & 4,2 & & 41.4 & 36.3 & 67 \\
\hline 2,41 & 0,12 & 0,02 & - & 0,05 & 0,01 & & 0,23 & 0,19 & 8 & 4,6 & 4,3 & & 44.0 & 37.2 & 55 \\
\hline 2,35 & 0,17 & 0,03 & - & 0,05 & 0,01 & & - & 0,25 & 11 & 5,0 & 4,5 & & 48.7 & 38.4 & - \\
\hline
\end{tabular}


pouco nítidas comuns; argila; maciço que se desfaz em blocos pequenos a médios moderado; muito duro, friável, plástico, muito pegajoso; raízes grossas pouco, médias e finas abundantes; galerias biológicas pequeras a médias comuns; macroporos comuns; carvões pequenos, pouco; limite suave, claro.

$\mathrm{A}_{12} \quad 14-44 \mathrm{~cm}$; amarelo $(2,5 Y 7,5 / 6 ; 10 \mathrm{YR} 7 / 6$ úmido); argila; maciço que se desfaz em blocos pequenos e granular pequena, fraco: duro, muito friável, plástico, muito pegajoso; raízes muito finas comuns; galerias biológicas pequenas comuns; macroporos comuns; limite suave, gradual.

$\mathrm{A}_{3} / \mathrm{B}_{1} \quad 44-85 \mathrm{~cm}$; amarelo (10YR8/8; $7 / 8$ úmido); argila; maciço que se desfaz em blocos pequenos, moderado; cerosidade comum; raízes médias pouco, finas comuns; macroporos pouco; limite suave, difuso.

$\mathrm{B}_{21} \quad 85-147 \mathrm{~cm}$; pardo muito pálido (10YR8/4; $7 / 8$ úmido): argila; maciço que se desfaz em blocos sub-angulares pequenos a médios, moderado; duro muito friável, plástico, muito pegajoso: cerosidade ou superfíceis de pressão, abundante; raizes finas pou-

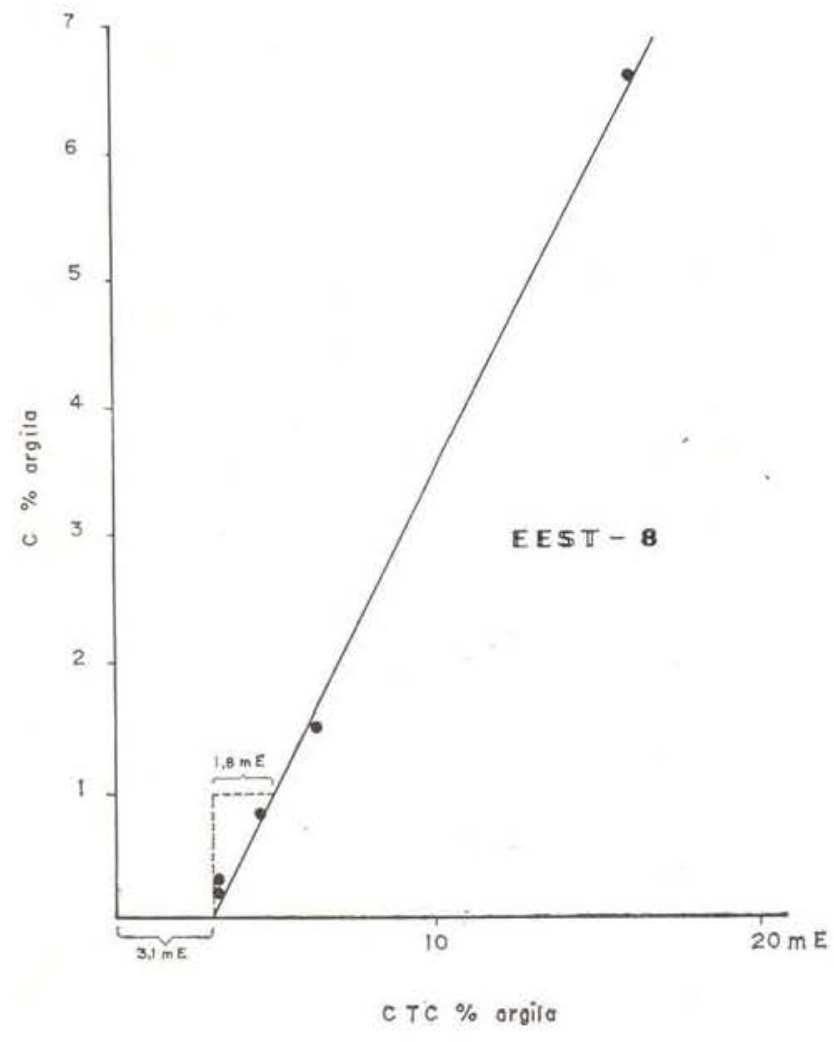

Fig. 15 - Relação C e CTC para $100 \mathrm{~g}$ de argila (segundo Bennema, 1966) correspondente ao perfil EEST - 8 . co; galerias biológicas pequenas, pouco; macroporos pouco; limite suave, difuso.

$\mathrm{B}_{22} \quad 147-210 \mathrm{~cm}$; pardo muito pálido (10YR8/3; 7/8 úmido); argila; maciço; duro, muito friável, plástico, muito pegajoso; cerosidade ou superfícies de pressãc pouco; raízes finas pouco; galerias biológicas pequenas pouco; limite suave, difuso.

$\mathrm{B}_{3} / \mathrm{C} 210-300+\mathrm{cm}$; pardo muito pálido (10YR8/4; 7/8 úmido); argila; maciço; duro, muito friável, plástico, muito pegajoso.

OBS.: A partir de $210 \mathrm{~cm}$, amostrado por tradagens.

Resultados analíticos do Perfil EEST-8

São apresentados no Quadro 9.

PERFIL EEST - 9

\section{Morfologia do Perfil EEST-9}

DATA: 11.08 .1977

CLASSIFICAÇÃO: TYPIC HAPLORTHOX

LATOSSOLO AMARELO, álico, A moderado, textura argilosa.

LOCALIZAÇÃO: Extremo $\mathrm{N}$ da área da Reserva de Campina, $a \pm 3000 \mathrm{~m}$ à direita da BR-174, ponto mais elevado da área.

GEOLOGIA: Formação Alter-do-Chão.

MATERIAL DE ORIGEM: Sedimentos argilosos.

RELEVO LOCAL: Plano.

RELEVO REGIONAL: Ondulado.

VEGETAÇÃO: Floresta Amazônica; Cumaru, Itaúba, Envira, Pau Mulato, Matá-matá, Caxí, Maçaranduba, Breu branco, Seringueira, Louro, Biorana.

DRENAGEM: Moderada a boa.

EROSÃO: Ausente.

USO ATUAL: -

MORFOLOGIA:

$\mathrm{A}_{11} \quad 0-12 \mathrm{~cm}$; matriz pardo muito pálido (10YR8/3; $7 / 4$ úmido), (10YR7/4 amassado) com $30 \%$ de áreas (10YR7/3) nítidas, comuns; argila; maciço que se desfaz em granular pequena, moderado; duro, muito friável, plástico, muito pegajoso; raizes grossas pou$\mathrm{co}$, finas comuns; galerias biológicas pequenas abundantes; macroporos comuns; limite suave, gradual.

$\mathrm{A}_{12} \quad 12-39 \mathrm{~cm}$; pardo muito pálido (10YR8/4; 7/6 úmido); argila; maciço que se rompe em micro-agregados, especialmente quando úmido; duro muito friável, plástico, muito pegajoso; raízes grossas pouco, finas comuns; galerias biológicas pequenas abundantes; macroporos em geral estrangulados, pouco; limite suave, gradual.

$\mathrm{A}_{3} / \mathrm{B}_{1} \quad 39-72 \mathrm{~cm} ;$ pardo muito pálido (10YR8/4; $7 / 8$ úmido); argila; maciço que se rompe em micro-agregados, moderado; duro, muito friável, plástico, muito pegajoso; áreas com 


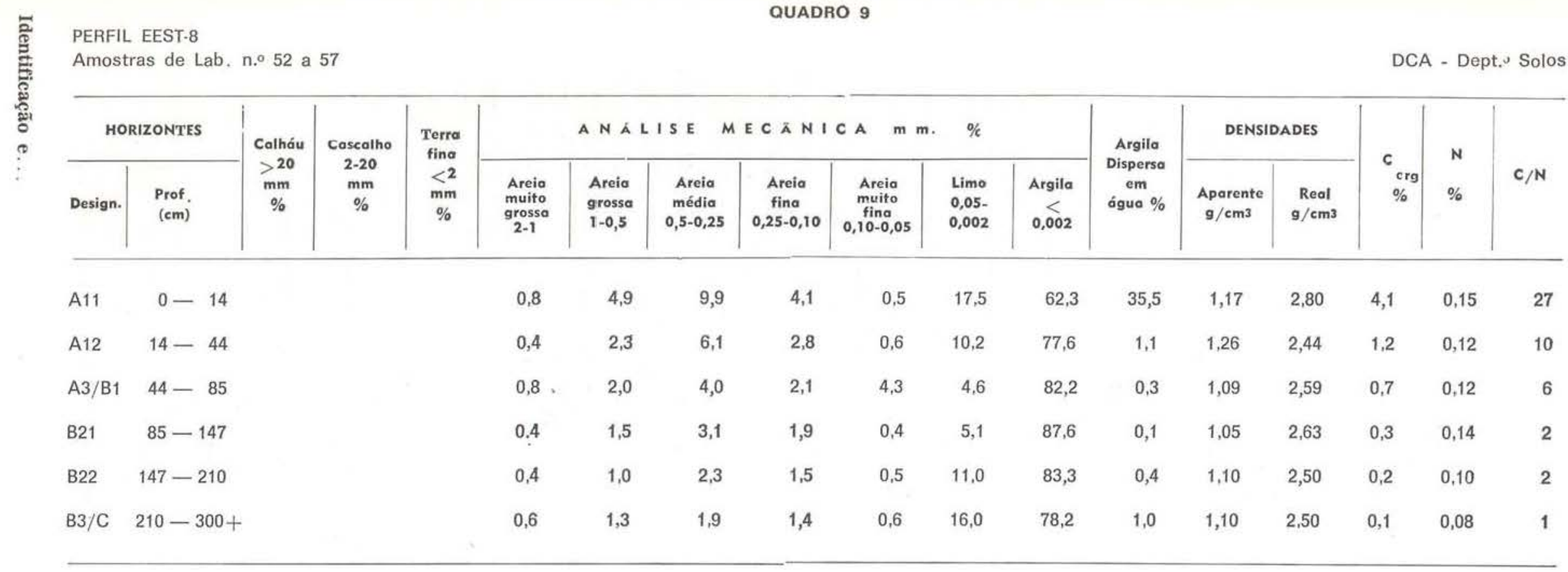

\begin{tabular}{|c|c|c|c|c|c|c|c|c|c|c|c|c|c|c|c|}
\hline \multirow{2}{*}{$\begin{array}{c}\text { СтC } \\
\text { e m g } \\
\%\end{array}$} & \multicolumn{5}{|c|}{$\begin{array}{c}\text { IONS TROCAVEIS } \\
\text { emg \% }\end{array}$} & \multicolumn{2}{|c|}{$\begin{array}{c}\text { ACIDEZ TROCÁVEL } \\
\text { e m g \% }\end{array}$} & \multirow{2}{*}{$\begin{array}{c}\text { Volor } \\
\text { S }\end{array}$} & \multirow{2}{*}{$\begin{array}{l}\text { Volor } \\
\text { V\% }\end{array}$} & \multicolumn{2}{|c|}{ pH $(1: 1)$} & \multicolumn{3}{|c|}{ UMIDADE/TENSŌES } & \multirow{2}{*}{$\begin{array}{l}100 \mathrm{Al} \\
\mathrm{Al}+\mathrm{S}\end{array}$} \\
\hline & $\mathrm{Ca}$ & $\mathrm{Mg}$ & $\mathbf{K}$ & $\mathrm{Na}$ & $\mathrm{PO}_{4}$ & $\mathrm{H}$ & Al & & & $\mathrm{H}_{2} \mathrm{O}$ & $\mathrm{KC}(\mathrm{N}$ & $\begin{array}{l}1 / 10 \\
\text { a t } m\end{array}$ & $\begin{array}{l}1 / 3 \\
\text { at m }\end{array}$ & $\begin{array}{l}15 \\
\text { of } m\end{array}$ & \\
\hline 10,02 & 0,24 & 0,18 & 0,21 & 0,13 & 0,02 & & 1,84 & 0,76 & 8 & 3,9 & 3,7 & & 34.8 & 29.2 & 71 \\
\hline 4,88 & 0,18 & 0,08 & 0,03 & 0,07 & 0,01 & & 1,09 & 0,36 & 7 & 4,1 & 3,9 & & 37.1 & 31.8 & 75 \\
\hline 3,85 & 0,14 & 0,04 & 0,01 & 0,06 & 0,01 & & 0,87 & 0,25 & 6 & 4,2 & 4,0 & & 39.0 & 32.8 & 78 \\
\hline 2,89 & 0,13 & 0,03 & - & 0,05 & 0,01 & & - & 0,21 & 7 & 4,4 & 4,4 & & 41.9 & 35.0 & - \\
\hline 2,61 & 0,13 & 0,04 & - & 0,06 & 0,01 & & - & 0,23 & 9 & 4,8 & 4,7 & & 43.1 & 36.9 & - \\
\hline 2,13 & 0,14 & 0,03 & - & 0,06 & 0,01 & & - & 0,23 & 11 & 5,0 & 4,8 & & 46.2 & 39.0 & - \\
\hline
\end{tabular}


micro-agregados entre formações maciças cerosas, comuns; raízes grossas rasas, finas pouco; galerias biológicas pequenas abundantes; macroporos deformados, comuns; limite suave, difuso.

$\mathrm{B}_{21} \quad 72-115 \mathrm{~cm}$; pardo muito pálido (10YR8/4; 7/8 úmido); argila; maciço que se rompe em micro-agregados, moderado; duro, muito friável, plástico, muito pegajoso; cerosidade comum intercalando áreas de acumulação de micro-agregados; raizes finas pouco; galerias biológicas pequenas, comuns; macroporos deformados, pouco; limite suave, difuso.

$\mathrm{B}_{22} \quad 115-158 \mathrm{~cm} ;$ pardo muito pálido (10YR8/4; 7,5YR7/6 úmido); argila; maciço que se rompe em micro-agregados; duro, muito friável, plástico, muito pegajoso; cerosidade intercalando áreas de micro-agregados, comum; raízes médias e finas, pouco; galerias biclógicas pequenas comuns; macroporos deformados, pouco; limite suave, difuso.

$\mathrm{B}_{3} / \mathrm{C} \quad 158-300+\mathrm{cm}$; pardo muito pálido (10YR8/4; 8/6 úmido); argila; maciço; áreas semelhantes a cerosidade comuns; duro, muito friável, plástico, muito pegajoso; raizes finas no terço superior.

OBS.: A partir de $200 \mathrm{~cm}$, amostras por tradagens.

Resultados analíticos do Perfil EEST-9 São apresentados no Quadro 10 .

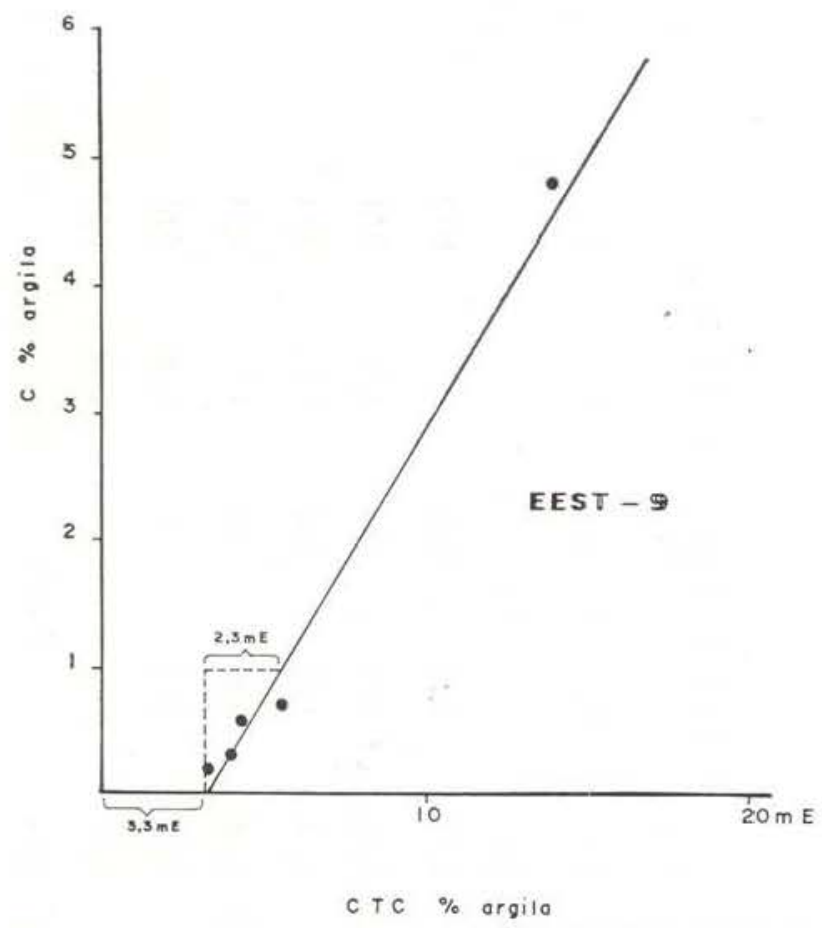

Fig. 16 - Relação C e CTC para $100 \mathrm{~g}$ de argila (segundo Bennema, 1966) correspondente ao perfil EEST - 9.
Classificação DOS SOLOS

CLASSIFICAÇÃO DO PERFIL EEST-1

O $A_{11}$ e $A_{12}$ caracterizam um epipedon ócrico.

Observa-se a partir do $B_{2 \uparrow}$ a presença de horizontes $B_{22}, B_{3}$ e $C$ com $\triangle p H=O$. A vista disto, foi primeiramente verificado se os horizontes de sub-superfície correspondiam a um óxico.

As exigências em espessura, textura, li. mites e ausência de estruturas rochosas são satisfeitas. A ocorrência do valor $(S+A I) \%$ argila apresentou os seguintes resultados, a partir do $A_{3}$ :

horizonte $B_{21} \ldots \ldots \ldots \ldots \ldots, 12,3 \%$

horizonte $B_{22} \ldots \ldots \ldots \ldots \ldots 16,7 \%$

horizonte $B_{3} \quad \ldots \ldots \ldots \ldots \ldots \ldots 15,7 \%$

horizonte C ............ 17,5\% donde se verifica que não satisfaz para óxico.

Para caracterizar um sub-horizonte argilico, há a presença dum forte gradiente textural entre os horizontes $A_{12}$ e $A_{3}$.

A ausência de línguas de materiais álbicos e de fragipan e ausência de plintita nos primeiros $30 \mathrm{~cm}$ tendem a caracterizar um Ultissol, tratando-se da subordem Humult em virtude de ocorrer 19,7 Kg de Carbono orgânico/ $\mathrm{m}^{2} / \mathrm{m}$ profundidade. A CTC $\%$ argila é :

horizonte $A_{3} \ldots 7,0$ emg $/ 100 \mathrm{~g}$ argila

horizonte $B_{21} \ldots 6,6$ emg $/ 100 \mathrm{~g}$ argila

horizonte $B_{22} \ldots 3,7 \mathrm{emg} / 100 \mathrm{~g}$ argila

horizonte $B_{3} \ldots 1,8 \mathrm{emg} / 100 \mathrm{~g}$ argila

horizonte C ...6.6, emg/100g argila

Como se observa, a CTC é inferior a 24 emg/100 de argila o que tende a situar este solo no grande grupo Palehumult, subgrupo Orthoxic Palehumult, que corresponde ao Podzólico Vermelho Amarelo, álico, Latossólico. A moderado, textura média.

\section{CLASSIFICAÇÃO DO PERFIL EEST-2}

Os horizontes $A_{11}$ e $A_{12}$ caracterizam um epipedon ócrico.

A partir do horizonte $B_{21}$ ocorre um $\Delta \mathrm{pH}=\mathrm{O}$ em profundidade até $\mathrm{o}_{2}$. Preliminarmente se considerou a presença de um horizonte óxico a partir do horizonte $A_{3} / B_{1}$ : 


\begin{tabular}{|c|c|c|c|c|c|c|c|c|c|c|c|c|c|c|c|c|c|}
\hline \multicolumn{15}{|c|}{$\begin{array}{l}\text { PERFIL EEST-9 } \\
\text { Amostras de Lab. n. } 58 \text { a } 63\end{array}$} & \multicolumn{3}{|c|}{ DCA - Dept. ${ }^{\circ}$ Solos } \\
\hline \multicolumn{2}{|c|}{ HORIZONTES } & \multirow{2}{*}{$\begin{array}{c}\text { Colhóu } \\
>20 \\
\text { mm } \\
\%\end{array}$} & \multirow{2}{*}{$\begin{array}{c}\text { Cosealho } \\
2-20 \\
m m \\
\%\end{array}$} & \multirow{2}{*}{$\begin{array}{c}\text { Terra } \\
\text { fina } \\
<2 \\
\mathbf{m m} \\
\%\end{array}$} & \multicolumn{3}{|c|}{ ANALISE } & \multicolumn{2}{|c|}{ MECÃNICA } & \multicolumn{2}{|l|}{$\%$} & \multirow{2}{*}{$\begin{array}{c}\text { Argile } \\
\text { Dispersa } \\
\text { em } \\
\text { ogua \% }\end{array}$} & \multicolumn{2}{|c|}{ DENSIDADES } & \multirow{2}{*}{$\begin{array}{l}c_{\text {org }} \\
\%\end{array}$} & \multirow{2}{*}{$\begin{array}{l}\mathrm{N} \\
\%\end{array}$} & \multirow[b]{2}{*}{$\mathrm{C} / \mathrm{N}$} \\
\hline Design. & $\begin{array}{l}\text { Prof. } \\
(\mathrm{cm})\end{array}$ & & & & $\begin{array}{c}\text { Areia } \\
\text { maito } \\
\text { grosso } \\
2-1\end{array}$ & $\begin{array}{l}\text { Areia } \\
\text { grossa } \\
1-0,5\end{array}$ & $\begin{array}{c}\text { Areia } \\
\text { média } \\
0,5-0,25\end{array}$ & \begin{tabular}{|c} 
Areia \\
fina \\
$0,25-0,10$
\end{tabular} & $\begin{array}{c}\text { Areeia } \\
\text { muito } \\
\text { fina } \\
0,10-0,05\end{array}$ & $\begin{array}{l}\text { Limo } \\
0,05- \\
0,002\end{array}$ & $\begin{array}{l}\text { Argila } \\
< \\
0,002\end{array}$ & & $\begin{array}{l}\text { Aparente } \\
\mathrm{g} / \mathrm{cm}^{3}\end{array}$ & $\begin{array}{c}\text { Real } \\
\mathrm{g} / \mathrm{cm}^{3}\end{array}$ & & & \\
\hline A11 & $0-12$ & & & & 0,5 & 2,3 & 4,9 & 2,3 & 0,3 & 19,7 & 70,0 & 435 & 1,16 & 2,48 & 3,4 & 0.23 & 15 \\
\hline $\mathrm{A} 12$ & $12-39$ & & & & 0,2 & 1,2 & 2,7 & 1,1 & 0,7 & 8.3 & 85,8 & 0,6 & 122 & 254 & 0.6 & 0.12 & 5 \\
\hline A3/B1 & $39-72$ & & & & 0,5 . & 1,6 & 2,3 & 1,2 & 0,3 & 5,5 & 88,6 & 0.4 & 1,17 & 2,62 & 0,5 & 0,11 & 4 \\
\hline B21 & $72-115$ & & & & 0,2 & 12 & 2.0 & 10 & 0,3 & 8.7 & 86,6 & 1.2 & 1,45 & 2,48 & 0.3 & 0,08 & 4 \\
\hline B22 & $115-158$ & & & & 0,2 & 0,9 & 1,7 & 1,1 & 0,3 & 7,0 & 88,8 & 0,8 & 1,16 & 2,53 & 0,2 & 0,08 & 2 \\
\hline $\mathrm{B} 3 / \mathrm{C}$ & $158-300+$ & & & & 0,2 & 0,7 & 1,2 & 0,7 & 0,2 & 11,0 & 86,0 & 0.7 & 1,21 & 2,40 & 0.2 & 0,09 & 2 \\
\hline
\end{tabular}

\begin{tabular}{|c|c|c|c|c|c|c|c|c|c|c|c|c|c|c|c|}
\hline \multirow{2}{*}{$\begin{array}{c}\text { стс } \\
\text { e m g } \\
\%\end{array}$} & \multicolumn{5}{|c|}{ 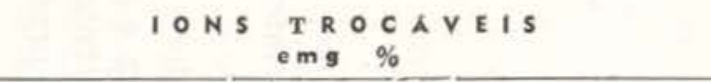 } & \multicolumn{2}{|c|}{$\begin{array}{l}\text { ACIDEZ TROCÁVEL } \\
\text { e } \mathrm{mg} \%\end{array}$} & \multirow{2}{*}{$\begin{array}{l}\text { Valor } \\
\text { s }\end{array}$} & \multirow{2}{*}{$\begin{array}{l}\text { Votor } \\
\text { v\% }\end{array}$} & \multicolumn{2}{|c|}{$P H(1: 1)$} & \multicolumn{3}{|c|}{ UMIDADE/TENSÖES } & \multirow{2}{*}{$\begin{array}{l}100 \mathrm{Al} \\
\mathrm{Al}+\mathrm{S}\end{array}$} \\
\hline & ca & $\mathrm{Mg}$ & к & $\mathrm{No}$ & $\mathrm{PO}_{4}$ & H & AI & & & $\mathrm{H}_{2} \mathrm{O}$ & $\mathrm{Kc}(\mathrm{N}$ & $\begin{array}{l}1 / 10 \\
a+m\end{array}$ & $\begin{array}{l}1 / 3 \\
a+m\end{array}$ & $\begin{array}{l}15 \\
0+m\end{array}$ & \\
\hline 9,91 & 0.19 & 0.19 & 0,34 & 0,15 & 0,03 & & 1,68 & 0,87 & 9 & 3,9 & 3,6 & & 38.4 & 33.0 & 66 \\
\hline 4,97 & 0,12 & 0,07 & 0,03 & 0,07 & 0,01 & & 0,92 & 0.29 & 6 & 4,2 & 4,0 & & 35.9 & 32.2 & 76 \\
\hline 3.96 & 0,14 & 0,05 & 0,01 & 0.06 & 0.01 & & 0.81 & 0.26 & 6 & 4,2 & 4,0 & & 36.6 & 32.7 & 76 \\
\hline 3,46 & 0,12 & 0,02 & - & 0,04 & 0,01 & & 0.81 & 0,18 & 5 & 4,3 & 4.0 & & 37.1 & 33.8 & 82 \\
\hline 3,08 & 0,12 & 0,02 & - & 0.06 & 0,01 & & 0,70 & 0,20 & 6 & 4,5 & 4,1 & & 44.3 & 34.6 & 78 \\
\hline 2,71 & 0,13 & 0.02 & 0,02 & 0,06 & 0,01 & & 0.45 & 0,23 & 8 & 4,7 & 4,2 & & 41.5 & 36.0 & 66 \\
\hline
\end{tabular}


como se observa, as condições de espessura, de ausência de minerais intémperizáveis, textura, limites e de ausência de estruturas rochosas são satisfeitas.

Quanto ao valor $\frac{\mathrm{S}+\mathrm{Al}}{\% \text { argila }} \times 100<10 \mathrm{emg}$ :

horizonte $A_{3} / B_{1} \ldots 18,3 \mathrm{emg} / 100 \mathrm{~g}$ de argila horizonte $B_{21} \ldots 16,3 \mathrm{emg} / 100 \mathrm{~g}$ de argila horizonte $B_{22} \ldots 13,9 \mathrm{emg} / 100 \mathrm{~g}$ de argila horizonte $B_{3} \ldots \ldots 13,2 \mathrm{emg} / 100 \mathrm{~g}$ de argila horizonte $C_{1} \ldots 17,7 \mathrm{emg} / 100 \mathrm{~g}$ de argila horizonte $\mathrm{C}_{2} \ldots \ldots \quad 7,2 \mathrm{emg} / 100 \mathrm{~g}$ de argila donde, apenas 0 horizonte $\mathrm{C}_{2}$ satisfaria para caracterizar um horizonte óxico.

Observa-se a presença de um gradiente textural entre os horizontes $A_{12}$ e $A_{3} / B_{1}$, a presença de cerosidade (?) ou superfícies de pressão nos horizontes $A_{3} / B_{1}, B_{21}$ e $B_{22}$, a presença de poros com secções transversais deformadas, o que tenderia a caracterizar a presença de um horizonte argilico a partir de $45 \mathrm{~cm}$ de profundidade, donde a presença de um ULTISSOL.

$O$ regime de umidade e a presença de $15,8 \mathrm{Kg}$ de carbono orgânico por $\mathrm{m}^{2}$, por metro de profundidade, contudo com menos de $0,9 \% \mathrm{C}$ nos primeiros $15 \mathrm{~cm}$ do horizonte argilico, caracterizam a sub-ordem UDULT, grande grupo PALEUDULT e subgrupo TYPIC PALEUDULT, que corresponde ao PODZÓLICO VERMELHO AMARELO, álico, A moderado, textura argilosa.

\section{CLASSIFICAÇÃO DO PERFIL EEST-3}

Os horizontes $A_{11}$ e $A_{12}$ caracterizam um epipedon ócrico.

Para caracterizar um horizonte óxico, o valor (S + Al) \% argila ₹10 emg somente é apresentado pelos horizontes $\mathrm{B}_{2}$ e $\mathrm{B}_{3} / \mathrm{C}$.

A possibilidade de ocorrência dum horizonte argilico com $71 \mathrm{~cm}$ de espessura a partir do horizonte $A_{12}$ é sugerida pelo gradiente textural entre o $A_{11}$ e $\circ A_{12}$ e assim, a presença de um ULTISSOL.

C conteúdo de carbono orgânico de $0,9 \%$ no topo do horizonte argílico e mais de $12 \mathrm{Kg}$ de carbono orgânico por $\mathrm{m}^{2} \mathrm{e}$ por metro de profundidade, sugerem a presença da subordem HUMULT. Não havendo diminuição de $20 \%$ do máximo de argila até $150 \mathrm{~cm}$ de profundidade. fica caracterizado o grande grupo PALEHUMULT. A CTC $\%$ argila do horizonte argílico é :

$A_{12} \ldots \ldots \ldots \ldots 6,3 \mathrm{emg} / 100 \mathrm{~g}$ argiia

$A_{3} / B_{1} \ldots \ldots \ldots 4,7 \mathrm{emg} / 100 \mathrm{~g}$ argila

$B_{21} \ldots \ldots \ldots . \ldots 3,4 \mathrm{emg} / 100 \mathrm{~g}$ argila

donde é inferior a $24 \mathrm{emg} / 100 \mathrm{~g}$ argila, tratando-se do sub-grupo ORTHOXIC PALEHUMULT por apresentar argila de baixa atividade. Corresponde ao PODZÓLICO VERMELHO AMARE. LO, álico, Latossólico, A moderado, textura argilosa.

\section{CL.ASSIFICAÇÃO DO PERFIL EEST-4}

Os horizontes $A_{1}$ e $A_{3}$ caracterizam um epipedon ócrico.

Tendendo caracterizar a presença de um horizonte argílico, a partir de $40 \mathrm{~cm}$ de profundidade, há a ocorrência de forte gradiente textural entre os horizontes $A_{3}$ e $B_{21}$, a presença de cerosidade (?) ou de superfícies de pressão (?) nos horizontes $B_{21}$ e $B_{22}$, tendendo pois sugerir a presença de um ULTISSOL

Os primeiros $15 \mathrm{~cm}$ do horizonte argílico (no horizonte $\mathrm{B}_{21}$ ) apresentam menos de 0,9\% de carbono orgânico e o perfil apresenta 9,4 $\mathrm{Kg}$ de carbono orgânico por $\mathrm{m}^{2}$ e por metro de profundidade. Estes fatos situam o solo na subordem UDULT porquanto o regime de umidade é údico.

Como o teor de argila no horizonte argílico não decresce mais de $20 \%$ do seu máximo até $150 \mathrm{~cm}$ da superfície do solo, é caracterizado - grande grupo PALEUDULT. As características apresentadas definem o subgrupo TYPIC PALEUDULT, que corresponde ao PODZÓLICO VERMELHO AMARELO, álico, A moderado, textura argilosa.

\section{CLASSIFICAÇÃo DO PERFIL EEST-5}

Os horizontes $A_{1}$ e $A_{3}$ caracterizam um epipedon ócrico.

Ocorre um $\triangle \mathrm{pH}=0$ no horizonte $\mathrm{C}$ : e a partir deste para cima ou para baixo ele tende a crescer. 
São satisfeitos os atributos de um horizonte óxico inclusive o valor (S + Al) \% argila inferior a $10 \mathrm{emg}$, como se depreende de:

$B_{21} \ldots \ldots \ldots, 2,9 \mathrm{emg} / 100 \mathrm{~g}$ argila

$\mathrm{B}_{22} \ldots \ldots \ldots 10,0 \mathrm{emg} / 100 \mathrm{~g}$ argila

$B_{3} \quad \ldots \ldots \ldots .99,0 \mathrm{emg} / 100 \mathrm{~g}$ argila. Logo está caracterizada a ordem OXISSOL.

O regime de temperatura isohipertérmico e o regime de umidade údico caracterizam a subordem ORTHOX.

A textura, saturação em bases, valor (S + Al) \% argila e conteúdo de carbono urgânico até $75 \mathrm{~cm}$ de profundidade situam este solo no grande grupo HAPLORTHOX. As características presentes neste solo o situam no subgrupo TYPIC HAPLORTHOX, que corresponde ao LATOSSOLO AMARELO, álico, A moderado, textura argilosa.

\section{CLASSIFICAÇÃO DO PERFIL EEST-6}

Os horizontes $A_{11}, A_{21}$ e $A_{13}$ satisfazem a definição de um epipedon úmbrico.

A presença de um gradiente textural entre os horizontes $A_{12}$ e $A_{13}$ tende a sugerir a ocorrência de um horizonte argílico, a partir de $31 \mathrm{~cm}$ até $220 \mathrm{~cm}$ de profundidade, o que viria enquadrar o solo na ordem ULTISSOL. A presença de $1,2 \%$ de carbono orgânico nos piimeiros $15 \mathrm{~cm}$ do horizonte argílico e $17,3 \mathrm{Kg}$ de carbono orgânico por $\mathrm{m}^{2} \mathrm{e}$ por metro de profundidade no perfil do solo, caracterizam a subordem HUMULT.

O fato de o teor de argila não decrescer $20 \%$ de seu máximo $(24,4 \%)$ até $150 \mathrm{~cm}$ de profundidade situa este solo no grande grupo PALEHUMULT. A presença de uma CTC $\%$ argila inferior a $24 \mathrm{emg}$ no horizonte argílico caracteriza o subgrupo ORTHOXIC PALEHU. MULT, que corresponde ao PODZÓLICO VERMELHO AMARELO, álico, Latossólico, A mo. derado, textura média.

\section{CLASSIFICAÇÃO DO PERFIL EEST-7}

Os horizontes $A_{11}$ e $A_{12}$ compõem um epipedon ócrico de $47 \mathrm{~cm}$ de espessura e o teor de limo é superior ao da areia total.
A possibilidade de ocorrência de um horizonte óxico é assegurada pelas exigências em espessura, ausência de minerais intemperizáveis, textura, limites, ausência de estruturas rochosas e :

(S $+\mathrm{Al}) \%$ argila $₹ 10 \mathrm{emg}:$

horizonte $B_{21} \ldots \ldots \ldots 9,9 \mathrm{emg} / 100 \mathrm{~g}$ argila horizonte $B_{22} \ldots \ldots \ldots 9,8 \mathrm{emg} / 100 \mathrm{~g}$ argila horizonte $B_{23} \ldots \ldots \ldots 5,1 \mathrm{emg} / 100 \mathrm{~g}$ argila horizonte $B_{3} \ldots \ldots \ldots 2,9 \mathrm{emg} / 100 \mathrm{~g}$ argila e $\mathrm{CTC} \%$ argila $<16 \mathrm{emg}$ :

horizonte $B_{21} \ldots \ldots \ldots 3,7 \mathrm{emg} / 100 \mathrm{~g}$ argila horizonte $B_{22} \ldots \ldots .3,6 \mathrm{emg} / 100 \mathrm{~g}$ argila horizonte $B_{23} \ldots \ldots \ldots 3,2 \mathrm{emg} / 100 \mathrm{~g}$ argila horizonte $B_{3} \ldots \ldots \ldots 2,8 \mathrm{emg} / 100 \mathrm{~g}$ argila ambos também satisfazendo e portanto caracterizando um OXISSOL; contudo não satisfaz para nenhuma subordem.

A possibilidade de ocorrência de um horizonte argilico é indicada pela presença de forte gradiente textural entre os horizontes $A_{11} \mathrm{e}$ $A_{12}$, pela ocorrência de cerosidade (?) oli superficies de pressão nos horizontes $B_{21}, B_{2}$, $B_{23}$ e $B_{3}$ tendendo sugerir um horizonte argílico desde 18 a $273 \mathrm{~cm}$ de profundidade e a presen. ça da ordem ULTISSOL.

A ocorrência de 1,1\% de carbono orgânico nos primeiros $15 \mathrm{~cm}$ do horizonte argílico e quase $11,4 \mathrm{Kg}$ de $C$ orgânico $/ \mathrm{m}^{2} / \mathrm{m}$ profundidade, sugerem a subordem UDULT marginal para HUMULT. Como não ocorre diminuição do máximo de argila em mais de $20 \%$ no horizonte argílico está caracterizado o grande grupo PALEUDULT e subgrupo TYPIC PALEUDULT, que corresponde ao PODZÓLICO VERMELHO AMARELO, álico, A moderado, textura argilosá.

CLASSIFICAÇÃO DO PERFIL EEST-8

Os horizontes $A_{11}$ e $A_{12}$ definem um epipedon ócrico de $44 \mathrm{~cm}$ de espessura, havendo ocorrência de um $\triangle \mathrm{pH}=0$ no horizonte $\mathrm{B}_{2:}$ e a tendência de o teor de limo ser superior ao da areia nos horizontes inferiores.

Para definir um horizonte óxico satisfaz quanto à espessura, ausência de minerais in- 
temperizáveis, limites, ausência de estruturas rochosas e $(\mathrm{S}+\mathrm{Al}) \%$ argila dos horizontes:

$A_{3} / B_{1} \ldots \ldots \ldots 10,9 \mathrm{emg} / 100 \mathrm{~g}$ de argila

$B_{21} \ldots \ldots \ldots \ldots \quad 1,6 \mathrm{emg} / 100 \mathrm{~g}$ de argila

$B_{22} \ldots \ldots \ldots \ldots, 0,3 \mathrm{emg} / 100 \mathrm{~g}$ de argila

$\mathrm{B}_{3} / \mathrm{C} \ldots \ldots \ldots \quad 0,3 \mathrm{emg} / 100 \mathrm{~g}$ de argila

e CTC $\%$ argila dos horizontes :

$A_{3} / B_{1} \ldots \ldots \ldots \quad 4,7 \mathrm{emg} / 100 \mathrm{~g}$ de argila

$B_{21} \ldots \ldots \ldots \ldots, 3,3 \mathrm{emg} / 100 \mathrm{~g}$ de argila

$\mathrm{B}_{22} \ldots \ldots \ldots \ldots .3,1 \mathrm{emg} / 100 \mathrm{~g}$ de argila

$\mathrm{B}_{3} / \mathrm{C} \ldots \ldots \ldots 2,7 \mathrm{emg} / 100 \mathrm{~g}$ de argila

Portanto, estão satisfeitos os atributos para um horizonte óxico a partir de $44 \mathrm{~cm}$ de profundidade, até $300 \mathrm{~cm}$, com espessura de $256 \mathrm{~cm}$, o que caracteriza a ordem OXISSOL.

O solo apresenta $15,2 \mathrm{~kg} \mathrm{C}$ orgânico $/ \mathrm{m}^{2} / \mathrm{m}$ profundidade, estando caracterizada a subordem ORTHOX contudo marginal para HUMOX.

A presença de menos de 1,5 emg de bases trocáveis + Alumínio trocável por $100 \mathrm{~g}$ de argila nos sub-horizontes $\mathrm{B}_{2}$ e $\mathrm{B} / 3 / \mathrm{C}$ situam este solo no grande grupo ACRORTHOX. Os atributos apresentados tendem a definir 0 subgrupo TYPIC ACRORTHOX, que corresponde ao LATOSSOLO AMARELO, álico, A moderado. textura argilosa.

\section{CLASSIFICAÇÃO DO PERFIL EEST-9}

Os horizontes $A_{11}$ e $A_{12}$ caracterizam um epipedon ócrico $c o m 39 \mathrm{~cm}$ de espessura. Nota-se que o teor de limo é superior ao de areia total.

As exigências em espessura, ausência de minerais intemperizáveis, textura, limites e ausência de estruturas rochosas tendem a definir a presença de um horizonte óxico.
O valor (S + Al) \% argila é :

horizonte $A_{3} / B_{1} \ldots 9,4 \mathrm{emg} / 100 \mathrm{~g}$ de argila horizonte $B_{21} \ldots 99,6 \mathrm{emg} / 100 \mathrm{~g}$ de argila horizonte $B_{22} \ldots 8,8,1 \mathrm{emg} / 100 \mathrm{~g}$ de argila horizonte $B_{3} / C_{2} \ldots 5,5 \mathrm{emg} / 100 \mathrm{~g}$ de argila donde também satisfaz por ser inferior a 10 emg $/ 100 \mathrm{~g}$ argila.

O valor CTC \% argila é :

horizonte $A_{3} / B_{1} \ldots 4,5 \mathrm{emg} / 100 \mathrm{~g}$ de argila horizonte $B_{21} \ldots 4,5 \mathrm{emg} / 100 \mathrm{~g}$ de argila horizonte $B_{22} \ldots 3,5,5 \mathrm{emg} / 100 \mathrm{~g}$ de argila horizonte $B_{3} / C \ldots 3,1 \mathrm{emg} / 100 \mathrm{~g}$ de argila donde também satisfaz por ser inferior a 16 emg $/ 100 \mathrm{~g}$ argila; donde é caracterizado um OXISSOL.

A presença do regime de umidade údico e de $10 \mathrm{Kg} \mathrm{C}$ orgânico $/ \mathrm{m}^{2} / \mathrm{m}$ profundidade tendem a definir a subordem ORTHOX.

A presença de teores de $(\mathrm{S}+\mathrm{Al}) \%$ argila superiores a $1,5 \mathrm{emg}$, saturação em bases inferior a $35 \%$, e outros atributos, identificam o grande grupo HAPLORTHOX, caracterizando o subgrupo TYPIC HAPLORTHOX, que corres. ponde ao LATOSSOLO AMARELO, álico, A moderado, textura argilosa.

No Quadro 11 é apresentada a classificação dos perfis de solos da EEST, segundo a Soil Taxonomy (1975).

Como se pode observar, há maior incidência de Uitissol ou de solos Podzolizados nos campos experimentais da Estação de Silvicultura Tropical.

ÁGUA DISPONÍVEL NOS PERFIS DE SOLO

Aplicando o método sugerido por Ranzani (1971), foi avaliada a água disponível presente em cada solo, nos diferentes meses do ano.

QUADRO 11 - Classificação dos solos segundo Soill Taxonomy (1975)

\begin{tabular}{lll|l|c}
\hline Ordem & Subordem & Grande grupo & Subgrupo & Perfis n.o \\
\cline { 1 - 1 } & Humult & Palehumult & Orthoxic Palehumult & $3-6$ \\
Ultissol & Humult & Tropohumult & Orthoxic Tropohumult & 1 \\
Ultissol & Udult & Paleudult & Typic Paleudult & $2-4-7$ \\
Oxissol & Orthox & Haplorthox & Typic Haplorthox & $5-9$ \\
Oxissol & Orthox & Acrorthox & Typic Acrorthox & 8 \\
& & & & \\
\hline
\end{tabular}


tomando por base as diferenças entre precipitação e evapotranspiração potencial da região de Manaus, num período superior a 10 anos.

MARCHA ANUAL DA ÁGUA DISPONIVEL NO PERFIL EEST - 1

Como mostra a Fig. 17, este solo se apresenta seco num período de:

-3 meses (A, S, O) até $80 \mathrm{~cm}$ de profundidade;

-4 meses (A, S, O, N) de 80 a $115 \mathrm{~cm}$ de profundidade;

-3 meses (S, O, N) de 115 a $219 \mathrm{~cm}$ de profundidade;

-2 meses (O, N) de 219 a $235 \mathrm{~cm}$ de profundidade;

- 3 meses (O, N, D) de 235 a $250 \mathrm{~cm}$ de profundidade.

A partir de $250 \mathrm{~cm}$ de profundidade, não há falta de água disponível neste solo, em qualquer época do ano.

MARCHA ANUAL DA ÁGUA DISPONÍVEL NO PERFIL EEST - 2

Como indicado na Fig. 17, este solo apre senta-se seco num período de :

- 3 meses (A, S, O) até $70 \mathrm{~cm}$ de profundidade;

-4 meses (A, S, O, N) de 70 a $115 \mathrm{~cm}$ de profundidade;

- 3 meses (S, O, N) de 115 a $215 \mathrm{~cm}$ de profundidade;

-2 meses $(\mathrm{O}, \mathrm{N})$ de 215 a $235 \mathrm{~cm}$ de profundidade;

-3 meses (O, N, D) de 235 a $260 \mathrm{~cm}$ de profundidade.

A partir de $260 \mathrm{~cm}$ de profundidade, o solo apresenta água em disponibilidade para as plantas durante todo $c$ ano.

MARCHA ANUAI DA ÁGUA DISPONIVEL NO PERFIL EEST - 3

A Fig. 17 mostra que este solo se apresenta seco num periodo de :

-3 meses (A, S, O) até a profundidade de $50 \mathrm{~cm}$;
-4 meses (A, S, O, N) de 50 a $80 \mathrm{~cm}$ de profundidade;

- 3 meses (S, O, N) de 80 a $210 \mathrm{~cm}$ de profundidacie;

-2 meses $(\mathrm{O}, \mathrm{N})$ de 210 a $223 \mathrm{~cm}$ de profundidade;

- 3 meses (O, N, D) de 223 a $250 \mathrm{~cm}$ de profundidade.

MARCHA ANUAL DA ÁGUA DISPONÍVEL NO PERFIL EEST - 4

A Fig. 17 mostra que este solo se apresenta seco nos seguintes períodos:

- 3 meses (A, S, O) até $40 \mathrm{~cm}$ de profundiciade;

- 4 meses (A, S, O, N) de 40 a $55 \mathrm{~cm}$ de profundidade;

-3 meses (S, O, N) de 55 a $105 \mathrm{~cm}$ de profundidade:

- 2 meses (O, N) de 105 a $120 \mathrm{~cm}$ de profundidade:

- 3 meses (O, N, D) de 120 a $130 \mathrm{~cm}$ de profundidade.

A partir de $130 \mathrm{~cm}$ de profundidade este solo não apresenta deficiência de água disponível durante todo o ano.

MARCHA ANUAL DA ÁGUA DISPONÍVEL NO PERFIL EEST - 5

A Fig. 17 mostra que este solo se apresenta seco nos seguintes períodos:

- 3 meses (A, S, O) até $45 \mathrm{~cm}$ de profundidade;

- 4 meses (A, S, O, N) de 45 a $70 \mathrm{~cm}$ de profundidade;

-3 meses (S, O, N) de 70 a $228 \mathrm{~cm}$ de profundidade;

-2 meses $(\mathrm{O}, \mathrm{N})$ de 228 a $250 \mathrm{~cm}$ de profundidade;

- 3 meses (O, N, D) de 250 a $270 \mathrm{~cm}$ de profundidade.

A partir de $270 \mathrm{~cm}$ de profundidade, este solo não apresenta deficiência de água disponivel durante todo o ano. 

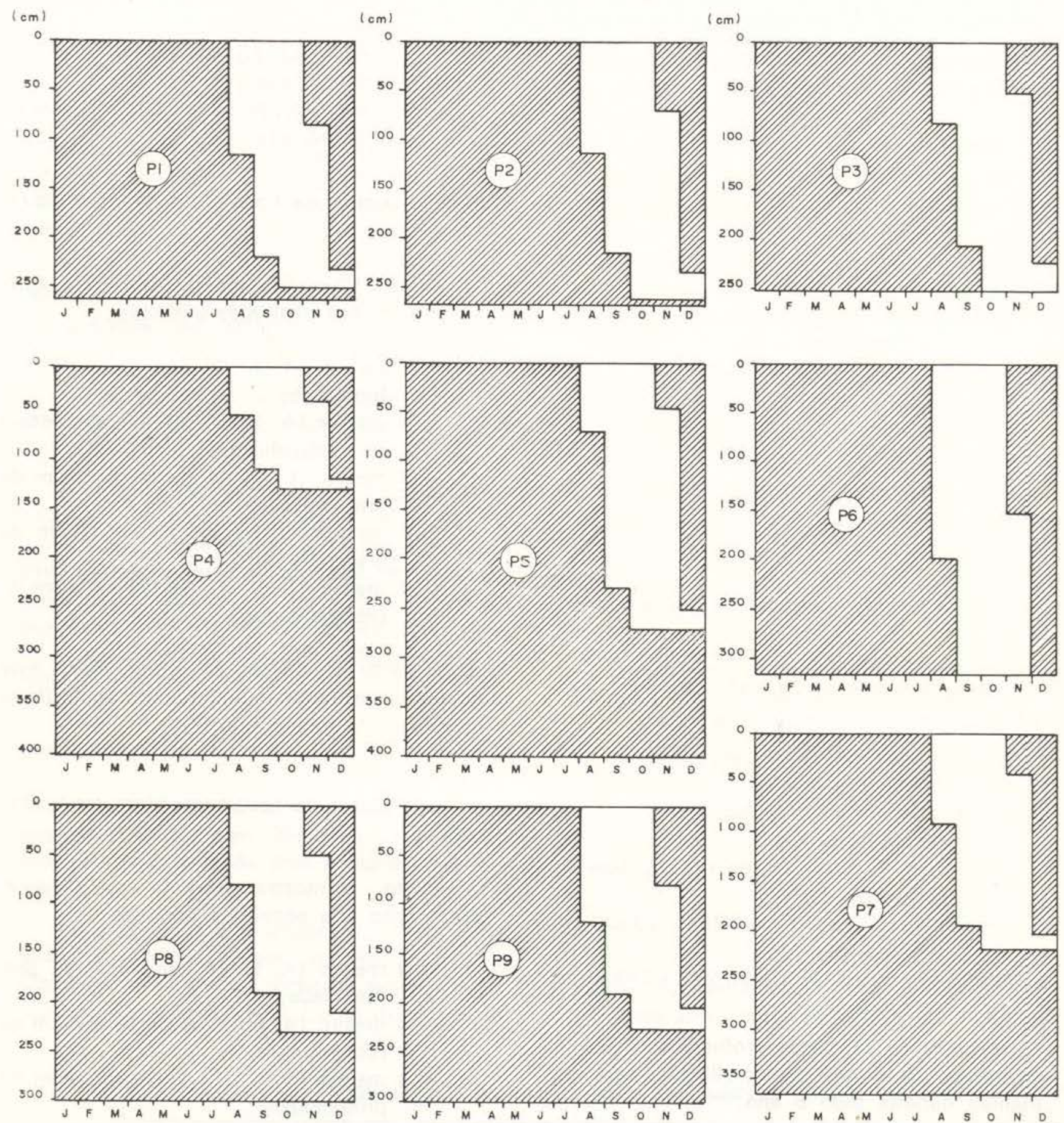

Com àgua disponivel

Sem água disponivel

Fig. 17 - Marcha anual da água disponível nos perfís de solo de terras da Estação Experimental de Silvicultura Tropical do INPA. 
MARCHA ANUAL DA ÁGUA DISPONÍVEL NO PERFII EEST - 6

A Fig. 17 mostra que este solo se apre. senta seco durante:

-3 meses $(A, S, O)$ até $150 \mathrm{~cm}$ de profundidade;

- 4 meses (A, S, O, N) de 150 a $195 \mathrm{~cm}$ de profundidade;

-3 meses (S, O, N) de 195 a $315 \mathrm{~cm}$ de profundidade.

MARCHA ANUAL DA ÁGUA DISPONÍVEL NO PERFIL EEST - 7

A Fig. 17 mostra que este solo se apresenta seco durante:

- 3 meses (A, S, O) até $40 \mathrm{~cm}$ de profundidade;

-4 meses (A, S, O, N) de 40 a $90 \mathrm{~cm}$ de profundidade;

-3 meses (S, O, N) de 90 a $195 \mathrm{~cm}$ de profundidade;

-2 meses $(\mathrm{O}, \mathrm{N})$ de 195 a $205 \mathrm{~cm}$ de profundidade;

- 3 meses (O, N, D) de 205 a $220 \mathrm{~cm}$ de profundidade.

O solo não apresenta deficiência de água disponível, a partir de $220 \mathrm{~cm}$ de profundidade, durante $o$ ano todo.

MARCHA ANUAL DA ÁGUA DISPONÍVEL NO PERFII EEST - 8

A Fig. 17 mostra que o solo se apresenta seco nos seguintes períodos:
- 3 meses (A, S, O) até $55 \mathrm{~cm}$ de profundidade;

-4 meses (A, S, O, N) de 55 a $80 \mathrm{~cm}$ de profundidade;

-3 meses (S, O, N) de 80 a $185 \mathrm{~cm}$ de profundidade;

-2 meses $(\mathrm{O}, \mathrm{N})$ de 185 a $210 \mathrm{~cm}$ de profundidade;

- 3 meses (O, N, D) de 210 a $230 \mathrm{~cm}$ de profundidade.

A partir de $230 \mathrm{~cm}$ de profundidade, não ocorre deficiência de água disponível, durante todo o ano.

MARCHA ANUAL DA ÁGUA DISPONIVEL NO PERFII EEST - 9

A Fig. 17 mostra que o solo se apresenta sem água disponível nos seguintes períodos:

-3 meses $(\mathrm{A}, \mathrm{S}, \mathrm{O})$ até $80 \mathrm{~cm}$ de profundidade;

-4 meses (A, S, O, N) de 80 a $115 \mathrm{~cm}$ de profundidade;

- 3 meses (S, O, N) de 115 a $190 \mathrm{~cm}$ de profundidade;

- 2 meses $(\mathrm{O}, \mathrm{N})$ de 190 a $205 \mathrm{~cm}$ de profundidade:

- 3 meses (O, N, D) de 205 a $225 \mathrm{~cm}$ de profundidade.

A partir de $225 \mathrm{~cm}$ de profundidade, não ocorre deficiência de água disponível, durante todo o ano.

No Quadro 12, são apresentados os resultados obtidos, os quais sugerem a presença

QUADRO 12 - Profundidade de ocorrência de água disponível nos perfis de solo da EEST.

\begin{tabular}{|c|c|c|c|c|c|c|}
\hline \multirow{3}{*}{$\begin{array}{l}\text { Perfil } \\
\text { N.e }\end{array}$} & \multicolumn{6}{|c|}{ Profundidade em $\mathrm{cm}$} \\
\hline & \multicolumn{5}{|c|}{ Periodos sem água disponivel } & \multirow{2}{*}{$\begin{array}{l}\text { Com água disponivel } \\
\text { durante todo } 0 \text { ano }\end{array}$} \\
\hline & 3 meses & 4 meses & 3 meses & 2 meses & 3 meses & \\
\hline 1 & $0-80$ & $80-115$ & $115-219$ & $219-235$ & $235-250$ & abaixo de 250 \\
\hline 2 & $0-70$ & $70-115$ & $115-215$ & $215-235$ & $235-260$ & abaixo de 260 \\
\hline 3 & $0-50$ & $50-80$ & $80-210$ & $210-223$ & $223-250$ & 一 \\
\hline 4 & $0-40$ & $40-55$ & $55-105$ & $105-120$ & $120-130$ & abaixo de 130 \\
\hline 5 & $0-45$ & $45-70$ & $70-228$ & $228-250$ & $250-270$ & abaixo de 270 \\
\hline 6 & $0-150$ & $150-195$ & $195-315$ & 一 & - & - \\
\hline 7 & $0-40$ & $40-90$ & $90-195$ & $195-205$ & $205-220$ & abaixo de 220 \\
\hline 8 & $0-55$ & $55-80$ & $80-185$ & $185-210$ & $210-230$ & abaixo de 230 \\
\hline 9 & $0-80$ & $80-115$ & $115-190$ & $190-205$ & $205-225$ & abaixo de 225 \\
\hline
\end{tabular}


de dois tipos de comportamento dos solos. relativamente ao suprimento de água em disponibilidade para as plantas :

1. solos que, a partir duma certa protun. didade, nunca perdem a água disponível e,

2. solos que, em toda extensão do perfil perdem toda a água disponível durante alguns meses do ano.

\section{AgRAdecimentos}

O Autor agradece ao Prof. Dr. Klaus Rei. chardt pelas determinações dos teores de água às tensões de $1 / 3$ e 15 bares e ao Prof. Dr. Henrique Bergamin Filho pela determinação dos trocáveis.

\section{SUMMARY}

This paper deals with the identification, morphclogical and analytical characterization of nine soils from the Estação Experimental de Silvicultura Tropical of INPA, located at the $\mathrm{Km} 45$ of the BR-174, between Manaus and Boa Vista.

The area has a isohyperthermic temperature regime and a uclic moisture regime.

The soil orders found were Ultisol and Oxisol. The Ultisol order has two suborders: Humult with two great groups (Palehumult and Tropohumult) and Udult, with one great group: Paleudult.

The Oxisol order has only one suborder (Orthox) with two great groups: Haplorthox and Acrorthox.

In the Brazilian soil classification system the soils belong to the Podzólico Vermelho Amarelo álico, Latossólico, A moderado, texturas média $\odot$ argilosa, and Latossolo Amarelo álico, A moderado, textura argilosa.

Results from available water during the year suggest, for some soils, this form of water the year over, at a depth of 130 to $270 \mathrm{~cm}$. In other soils, like the profiles 3 and 6 , no available water is present for 3 months/year.

\section{BIBLIOGRAFIA}

Albuquerque, O.R.

1922 - Reconhecimentos geológicos do vale do Amazonas. BRASIL. S. G. M. Rio de Janeiro, (3) : 84, il.
Amaral, S.E. Do

1954 - Nota sobre a Série Barreiras no vale do rio Tapajós. BRASIL. Soc. Bras. Geol. B. Săo Paulo, 3(1) : 29-50.

Anderson, A.B.: Prance, G.T. \& Albuquerque, B.W.P. DE

1975 - A vegetação lenhosa da Campina da Reserva Biológica INPA/SUFRAMA (Manaus. Caracarai, $\mathrm{Km} \mathrm{62)}$. Acta Amazonica, 5(3) : 225-246,

ANDERSON, A.B.

1978 - Aspectos florísticos e fitogeográficos de Campinas e Campinaranas na Amazônia Central. Tese de M. Sc., Instituto Nacional de Pesquisas da Amazônia (INPA) e Fundaçāo Universidade do Amazonas (FUA).

BENNEMA, J.

1966 - Report to the Government of Brazil on Classification of Brazilian Soils. Report $n .^{\circ}$ 2197. Project BRA/TE/LA.

Catani, R.A. \& Jacintho, A.O.

1974 - Análise química para avaliar a fertilidade do solo. Bol. Tec. Cient. ESALQ-USP, Piracicaba-SP, (37) : 1-57.

GoIs RIBEIro, M.N, DE

1977 - Contribuição hidrometeorológica para a regiāo de Manaus INPA (em impressão).

Heyliggers, P.C

1963 - Vegetation and soil of a white sand savanna in Suriname. N.V. Noord Hollandsche Vitgevers Maatschappic. Amsterdam.

JACKSON, M.L.

1958 - Soil chemical analysis. Prentice-Hall. Inc. Englewood Cliffs, N.J. 498 p.

Kilmer, V.J. \& Alexander, L.T.

1949 - Methods of macking mechanical analysis of soils. Soil Sci., $68: 15-24$.

KISTLER, $\mathrm{P}$.

1954 - Historical resume of the Amazon Basin BRASIL. Petrobrás. Relatório Inédito. Belém n.o 104.A.

MEHRA, O.P. \& JACKSON, M.L.

1960 - Iron oxide removal from soils and clays by a dithionite-citrate system buffered with sodium bicarbonate. In: Proc. 7th NatI. Conf. on Clays and Clay Minerals. p. 317-327, Permagon Press, New York.

PANDOLFo, C.M.

1959 - Notas sobre os depósitos de evaporitos da bacia Amazônica, minério de bauxita fosforosa no Maranhão. BRASIL. S.P.V.E.A., Belém, $1: 77$ il.

RAnzani, G.; KinJo, T. \& Freire, O.

1963 - Mecanismo de gênese dos areões soltos do arenito Botucatu. In: IX Congr. Bras. de Cienc. Solo, Fortaleza, Ceará. 
RANZANI, G.

1971 - Marcha anual da água disponível no solo. Centro de Estudos de Solos. ESALQ-USP. Piracicaba. 14 p. il.

RICHARDS, L.H.

1954 - Diagnosis and improvement of saline and alkali soils. USDA Handbook n.० 60 . Washington, D.C.

Santos, J.O.: Borges, O.C.; Veiga Júnior, J.P.: Silva, S.L. DA \& PEsson, M.R.

1974 - Projeto norte da Amazônia. Min. Minas e Energia DNPM. Convênio DNPM-CPRM. Relatório final integrado Vol. IV : 212-229.

SOL. TAXONOMY

1975 - A basic system of Soil Classification for making and interpretating soil surveys.
Agric. Handbook n.: 436 - SCS-USDA Washington, D.C.

Thorntwaite, C.W. \& Mather, J.R.

1955 - The water balance. Public. In: Climatology, 8(1), Centerton, N.Y.

Vira Nova, W.; Salati, E. \& Matsut, E.

1976 - Evapotranspiraçăo potencial da bacia Amazônica.

WalkLey, A. \& Black, T.A.

1934 - An examination of the Degtj reff Method for determining soil organic matter and a proposed modification of the Chromic Acid titration method. Soil Sci., $37: 29-38$.

(Aceito para publicaçăo em 11/06/79) 